PEMERINTAH DAERAH KOTAMADYA JAKARTA TIMUR

SUKU DINAS PERTAMANAN

\title{
PEMBANGUNAN SISTEM INFORMASI MANAJEMEN RTH TAMAN DAN JALUR HIJAU WILAYAH KOTAMADYA JAKARTA TIMUR
}
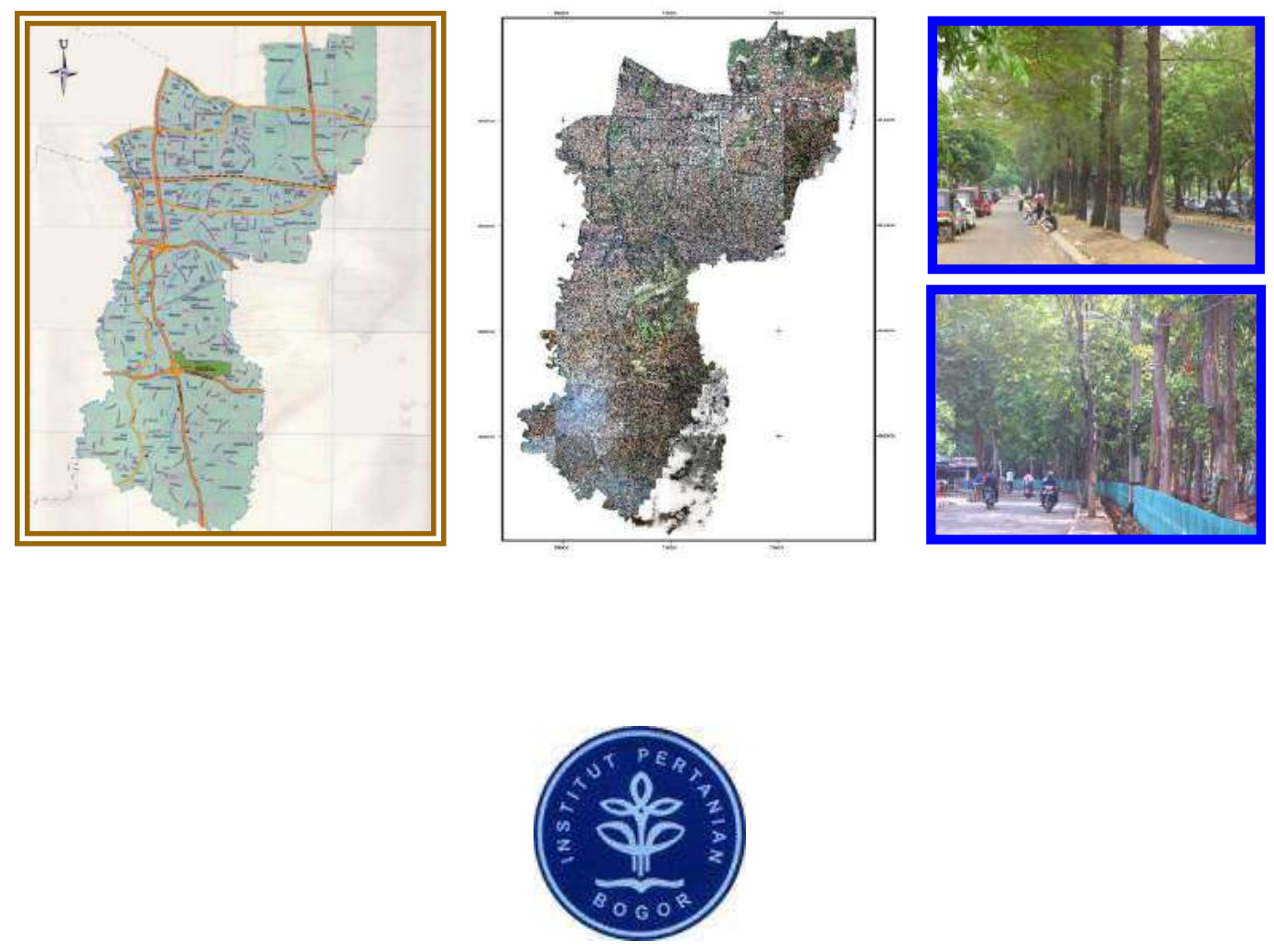

DEPARTEMEN ARSITEKTUR LANSKAP

FAKULTAS PERTANIAN

INSTITUT PERTANIAN BOGOR

TAHUN 2006 


\section{PEMERINTAH DAERAH KOTAMADYA JAKARTA TIMUR SUKU DINAS PERTAMANAN}

\section{PEMBANGUNAN SISTEM INFORMASI MANAJEMEN RTH TAMAN DAN JALUR HIJAU WILAYAH KOTAMADYA JAKARTA TIMUR}
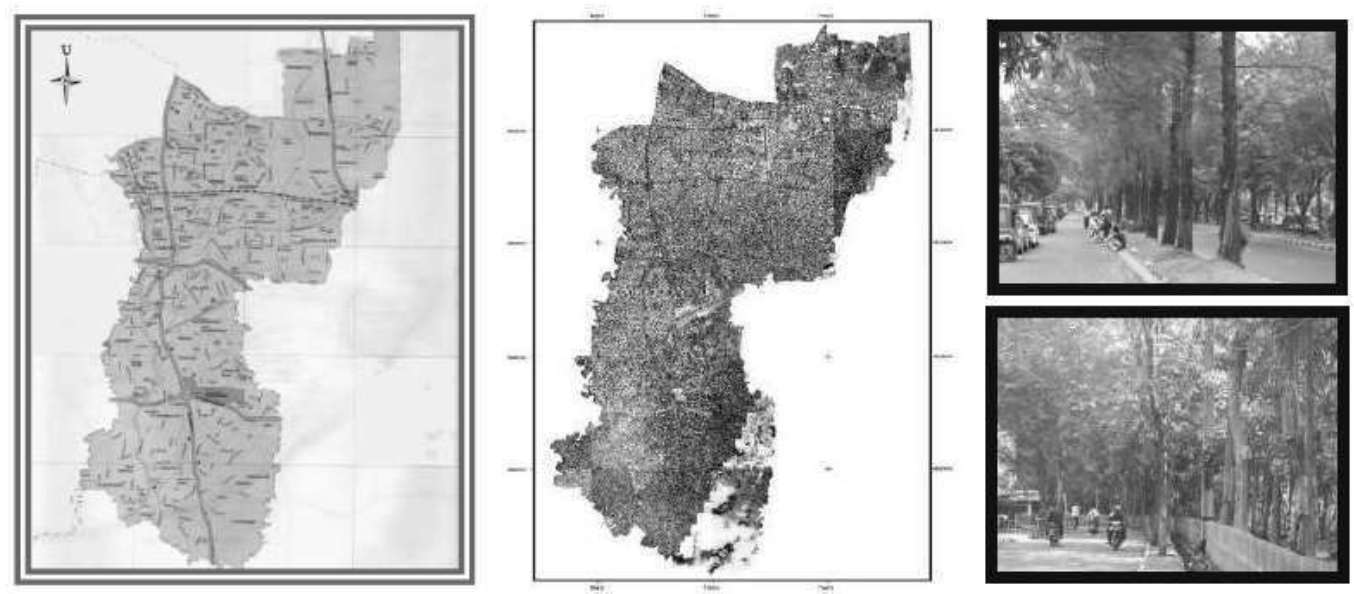

Tim Penulis:

B. Sulistyantara

I. W. Hidayat

A. N. Taher

Isdiyantoro

A. Kastolani

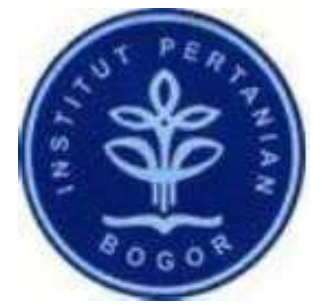

DEPARTEMEN ARSITEKTUR LANSKAP FAKULTAS PERTANIAN INSTITUT PERTANIAN BOGOR 2006 


\section{KATA PENGANTAR}

Pembangunan Sistem Informasi Manajemen RTH Taman dan Jalur Hijau Wilayah Jakarta Timur adalah suatu langkah penting dalam pengembangan dan pengelolaan Ruang Terbuka Hijau (RTH) di Jakarta Timur. Tanpa suatu landasan pendataan yang aktual, bisa dipastikan pengembangan dalam berbagai perencanaan ruang terbuka hijau akan mengalami hambatan di kemudian hari.

Sehubungan dengan itu maka salah satu upaya untuk mengantisipasinya adalah dengan dibuatnya suatu Pembangunan Sistem Informasi Manajemen RTH Taman dan Jalur Hijau Wilayah Jakarta Timur pada tahun 2006 ini sebagai lanjutan program kerja yang sama pada tahun 2005 yang lalu, sebagai bentuk penyempurnaan, up-dating serta penambahan input data yang ada di lapangan.

Laporan ini adalah merupakan tahap Akhir yang berupa Laporan Final dari rincian kegiatan Pembangunan Sistem Informasi Manajemen RTH Taman dan Jalur Hijau Wilayah Jakarta Timur.

Untuk itu kami mengucapkan terima kasih kepada semua pihak yang telah membantu dalam pelaksanaan penyusunan laporan ini.

Bogor, Desember 2006

Tim Penulis 
Wilayah KotamadyaJakarta Timur

\section{DAFTAR ISI}

\section{Kata Pengantar}

\section{Daftar Isi}

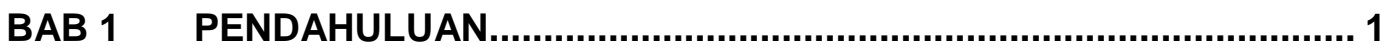

1.1. Latar Belakang ................................................................. 1

1.2. Perumusan Masalah...................................................... 2

1.3. Maksud dan Tujuan Kegiatan ............................................. 2

1.3.1. Maksud ................................................................. 2

1.3.2. Tujuan ........................................................... 2

1.4. Ruang Lingkup Kegiatan Survey..................................... 3

BAB 2 METODOLOGI PENGAMBILAN DATA .......................................... 4

2.1. Waktu dan Lokasi Pengambilan Data .................................... 4

2.2. Bahan dan Alat ................................................................. 5

2.2.1. Bahan ................................................................ 5

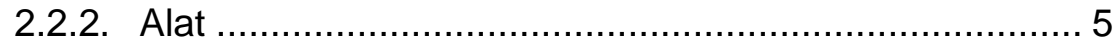

2.3. Metode Pengambilan Data ............................................... 5

2.3.1. Pengumpulan Data Pohon di Lapang........................... 6

2.3.1.1. Inventarisasi dan Pengukuran

Fisik Pohon............................................... 6

2.3.1.2. Penilaian Kondisi Fisik Pohon......................... 7

2.3.2. Pemetaan Data Pohon.............................................. 10

2.3.3. Pengolahan Basis Data Pohon..................................... 10

2.3.4. Penyajian Hasil ....................................................... 10

BAB 3 ANALISIS DAN HASIL KAJIAN ................................................. 16

3.1. Jalur Hijau Jalan Raya Bogor .............................................. 17

3.2. Jalur Hijau Jalan Mayjen Sutoyo......................................... 19

3.3. Jalur Hijau Jalan Jenderal Ahmad Yani ................................. 21

3.4. Jalur Hijau Jalan Raya Kalimalang ….................................. 23

3.5. Jalur Hijau Jalan Kayu Putih Raya ....................................... 25

3.6. RTH Kelompok Taman Dermaga ....................................... 26

3.7. RTH Taman Hutan Kota .................................................. 30

3.8. Hasil Pemetaan Letak Titik Pohon ....................................... 33

3.8.1. Pemetaan Titik Pohon Pada JHJ Raya Bogor .............. 33

3.8.2 Pemetaan Titik Pohon Pada JHJ Mayjen Sutoyo .......... 35

3.8.3. Pemetaan Titik Pohon Pada JHJ Jend A Yani............... 36

BAB 4 PEMBAHASAN DAN PEMBANGUNAN SISTEM............................ 37

4.1. Sistem Informasi Geografis................................................ 37

4.1.1. Analisis (Query) SIG ......................................... 38

4.1.2. Penyajian Hasil SIG ........................................... 39

4.2. Sistem Informasi Berbasis Objek ....................................... 40

4.2.1. Database dan Sistem Manajemen Database .............. 40

4.2.2. Peranti Visual Database......................................... 42

4.2.3. Perangkat Lunak SMBD Access2000 ........................ 42

4.2.4. Konfigurasi Perangkat Keras

SMBD Access2000 for Windows............................... 43 
Wilayah KotamadyaJakarta Timur

4.2.5. Aplikasi Manajemen Basisdata dengan Microsoft Visual Basic 6.0

4.3. Tampilan Program dan Sistem yang Dibangun ...................... 44

4.4. Potensi Pengembangan Pengelolaan

Ruang Terbuka Hijau

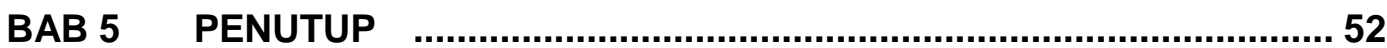

DAFTAR PUSTAKA

LAMPIRAN 


\section{BAB 1}

\section{PENDAHULUAN}

\subsection{LATAR BELAKANG}

Kota sebagai tempat untuk menampung segala aktivitas masyarakat, semakin lama akan semakin padat oleh berbagai kegiatan dengan segala fasilitasnya. Propinsi DKI Jakarta sebagai ibukota Republik Indonesia telah berkembang menjadi kota yang padat dengan penduduk dan kebutuhan akan tempat tinggal meningkat.

Pada saat ini kebutuhan masyarakat DKI Jakarta akan ruang terbuka hijau meningkat, dikarenakan adanya penurunan kualitas lingkungan perkotaan sebagai akibat tidak langsungnya aktivitas masyarakat. Menyadari kurangnya RTH di wilayah DKI Jakarta, sementara kebutuhan masyarakat Jakarta akan hal itu semakin tinggi maka keberadaan jalur hijau jalan sebagai salah satu bentuk RTH kota dinilai memiliki kontribusi yang cukup besar sebagai paru-paru kota. Tingginya aktivitas sirkulasi kendaraan mengakibatkan kemacetan lalu lintas, kebisingan, peningkatan suhu udara maupun pencemaran udara. Permasalahan yang lainnya adalah penampakan visual yang kurang menarik. Dengan demikian jalur hijau memiliki peranan yang sangat penting bagi lingkungan hidup perkotaan, yang dapat menciptakan lingkungan yang baik, sehat, indah, lestari dan berkesinambungan (Noor, 1990).

Salah satu bentuk hutan kota menurut Dahlan (1992) adalah jalur hijau dengan elemen utama pohon tepi jalan. Kehadiran pohon tepi jalan sangatlah penting untuk menciptakan lingkungan yang menyenangkan bagi pengguna jalan karena memiliki sifat fisiologis antara lain kemampuan meyerap polusi dan penghasil oksigen. Selain itu pohon memiliki sifat fisik yang dapat memberikan nilai estetika dari bentuk, tekstur, warna, aroma dan bagian lainnya.

Pembangunan yang lebih berpusat pada pembangunan fisik telah menyampingkan keberadaan Ruang Terbuka Hijau, khususnya jalur hijau jalan. Hal ini mempengaruhi kondisi fisik pohon dengan terlihatnya berbagai gejala kerusakan secara fisik dan visual. Gejala kerusakan ini akan mengurangi nilai fungsi dan estetis serta penurunan kondisi fisik pohon yang akan mempengaruhi kualitas lingkungan kota. Gejala kerusakan dan penurunan kondisi fisik pohon juga ditemui pada jalur hijau jalan di Kotamadya Jakarta Timur. Kerusakan- 
kerusakan tersebut menjadi masalah yang cukup vital apabila dikaitkan dengan kenyamanan dan keselamatan pengguna, terutama pengguna jalan. Pada musim penghujan, dimana curah hujan yang tinggi disertai dengan angin kencang dapat menyebabkan patah cabang atau bahkan pohon roboh. Hal ini sangat membahayakan kelancaran sirkulasi lalu-lintas pada jalan tersebut, sekligus keselamatan pengguna jalan.

Dalam kasus ini, maka sangat diperlukan pemantauan kondisi fisik pohon-pohon, terutama pada pohon tepi jalan. Pemantauan secara rutin dan berkala oleh pihak pengelola, dalam hal ini Sudin Pertamanan Kotamadya Jakarta Timur, dapat meninimalisasi dampak yang ditimbulkan oleh kondisi fisik pohon. Pemantauan dan pengelolaan tersebut meliputi pemantauan mengenai kerusakan fisik pohon, baik yang disebabkan oleh hama dan penyakit tanaman, maupun yang disebabkan oleh kerusakan mekanik.

Untuk mengetahui tingkat usaha pemantauan pengelolaan pohon maka harus diketahui data seperti inventarisasi pohon di Jalur Hijau Jalan, inventarisasi prasarana/sarana Jalur Hijau Jalan serta tingkat intensitas kegiatan pemeliharaan beserta data lainnya yang terkait. Oleh karena itu diperlukan suatu usaha pengendalian faktor pembatas yaitu ketersediaan informasi.

Masalah yang dihadapi Kotamadya Jakarta Timur dalam upaya pengelolaan pohon di Jalur Hijau Jalan dan RTH pertamanan adalah ketersediaan informasi mengenai pengelolaan khususnya pohon. Sistem Informasi Manajemen Pemeliharaan Pohon merupakan pedoman yang berguna untuk pertimbangan dalam pengelolaan, pemanfaatan dan pengembangan Jalur Hijau Jalan dan RTH pertamanan sehingga menghasilkan pola pengelolaan pemeliharaan yang lebih efisien dan lebih terarah.

\subsection{PERUMUSAN MASALAH}

- Data yang telah ada, belum mencakup keseluruhan area Ruang Terbuka Hijau Pertamanan yang dapat dijadikan acuan dalam mengimplementasikan rencana pengembangan dan pengelolaan pada taman dan jalur di wilayah Kotamadya Jakarta Timur yang secara spesifik.

- Data pertamanan dalam bentuk format digital dengan memanfaatkan teknologi informasi pada tahun 2005, belum menunjukkan interaksi data yang lengkap dan spesifik mengenai kondisi Ruang Terbuka Hijau (RTH) Pertamanan di wilayah Kotamadya Jakarta Timur. 


\subsection{MAKSUD DAN TUJUAN KEGIATAN STUDI}

\subsubsection{Maksud}

Pemerintah Kotamadya Jakarta Timur telah menetapkan suatu kegiatan Pembangunan sistem informasi manajemen RTH Pertamanan dan Jalur Hijau di kawasan Wilayah Kotamadya Jakarta Timur, dengan penekanan pada tamantaman dan pada jalur-jalur hijau yang diunggulkan, yang selanjutnya akan dipakai sebagai dasar pelaksanaan kegiatan Penataan Penghijauan (Pohon) Wilayah Kotamadya Jakarta Timur pada tahun anggaran 2006 ini.

\subsubsection{Tujuan}

Tujuan pembangunan sistem informasi manajemen RTH pertamanan ini adalah :

a. Tersedianya sistem informasi manajemen ruang terbuka hijau pertamanan dan jalur hijau wilayah Kotamadya Jakarta Timur, yang dapat diakses dengan mudah, lengkap, cepat dan akurat.

b. Tercapainya efisiensi waktu dan biaya dalam melakukan tugas-tugas pemeliharaan dan pengendalian taman dan jalur hijau di wilayah Kotamadya Jakarta Timur.

c. Meningkatkan tanggung jawab Suku Dinas Pertamanan Kotamadya Jakarta Timur, sehingga dapat melakukan tugas-tugas pemeliharaan dan pengendalian asset RTH dengan lebih baik.

d. Meningkatkan kualitas komunikasi timbal balik antara Suku Dinas Pertamanan Kotamadya Jakarta Timur dengan masyarakat luas yang membutuhkan dan atau yang berperan serta dalam pemeliharaan asset RTH kota.

\subsection{RUANG LINGKUP KEGIATAN STUDI}

Kegiatan studi ini dibatasi pada 5 (lima) lokasi jalur hijau jalan di Kotamadya Jakarta Timur, yaitu: (1) Jalur Hijau Jalan Raya Bogor; (2) Jalur Hijau Jalan Mayjen Sutoyo; (3) Jalur Hijau Jalan Jenderal Ahmad Yani; (4) Jalur Hijau Jalan Raya Kalimalang, dan; (5) Jalur Hijau Jalan Kayu Putih Raya. Sedangkan Ruang Terbuka Hijau (RTH) taman terdiri atas 2 (dua) lokasi, yaitu: (1) Taman Hutan Kota Kompleks Perumahan karyawan Pemda DKI Pondok Kelapa, Duren Sawit, dan; (2) Taman Dermaga, Duren Sawit. 


\section{BAB 2 METODOLOGI PENGAMBILAN DATA}

\subsection{WAKTU DAN LOKASI PENGAMBILAN DATA}

Pelaksanaan kegiatan studi ini dilakukan di wilayah Kotamadya Jakarta Timur pada bulan Oktober 2006. Lokasi studi memiliki posisi geografi $106^{\circ} 49^{\prime}$ $35^{\prime \prime}$ BT sampai $06^{\circ} 10^{\prime} 37^{\prime \prime}$ LS. Dengan luas wilayah $\pm 187,77 \mathrm{~km}^{2}$ atau $\pm 28,37$ \% luas DKI Jakarta.

Dalam kajian Pembangunan Sistem Informasi Manajemen RTH Taman dan Jalur Hijau Jalan Wilayah Jakarta Timur ini dibatasi pada jalur-jalur hijau jalan protokol dan taman, yang terdapat di wilayah Kotamadya Jakarta Timur. Inventarisasi potensi pohon-pohon yang ada di wilayah Kotamadya Jakarta Timur akan dilakukan pada 5 jalur hijau jalan utama, yaitu:

\section{(1) Jalur Hijau Jalan Raya Bogor}

Terdiri atas sisi Barat dan Timur jalan raya, yang membentang (SelatanUtara), sejak dari turunan fly-over Pasar Rebo hingga pertigaan PGC Cililitan.

\section{(2) Jalur Hijau Jalan Mayjen Sutoyo}

Terdiri atas sisi Barat dan Timur jalan raya serta bagian median jalan, yang membentang (Selatan-Utara) sejak pertigaan PGC Cililitan hingga fly-over Cawang.

(3) Jalur Hijau Jalan Jenderal Ahmad Yani

Terdiri atas sisi Barat dan Timur jalan raya, yang membentang (SelatanUtara) sejak turunan fly-over Jatinegara hingga persimpangan antara Jalan Pemuda - Pramuka, serta sisi Timur jalan raya hingga persimpangan Jalan Letjen Suprapto-Perintis Kemerdekaan-Laksamana Yos Sudarso.

(4) Jalur Hijau Jalan Raya Kalimalang

Terdiri atas sisi Utara dan Selatan jalan raya serta traffic-island (pulau jalan), yang membentang (Barat-Timur) sejak Kalimalang Cipinang Muara hingga Pasar Sumber Artha.

(5) Jalur Hijau Jalan Kayu Putih Raya

Terdiri atas sisi sisi Barat dan separator, sisi Timur dan separator serta median jalan, membentang (Selatan-Utara) sejak persimpangan Jalan 
Wilayah KotamadyaJakarta Timur

Tanah Mas Kayu Putih hingga persimpangan antara Jalan Perintis Kemerdekaan.

Ruang Terbuka Hijau (RTH) taman yang termasuk di dalam studi ini terdiri atas 2 (dua) lokasi, yaitu:

(1) Taman Hutan Kota Kompleks Perumahan karyawan Pemda DKI Pondok Kelapa, Jalan H. Dogol, Jalan Pondok Kelapa Raya, Pondok Kelapa, dan;

(2) Taman Dermaga, Jalan Duren Sawit Raya, Duren Sawit.

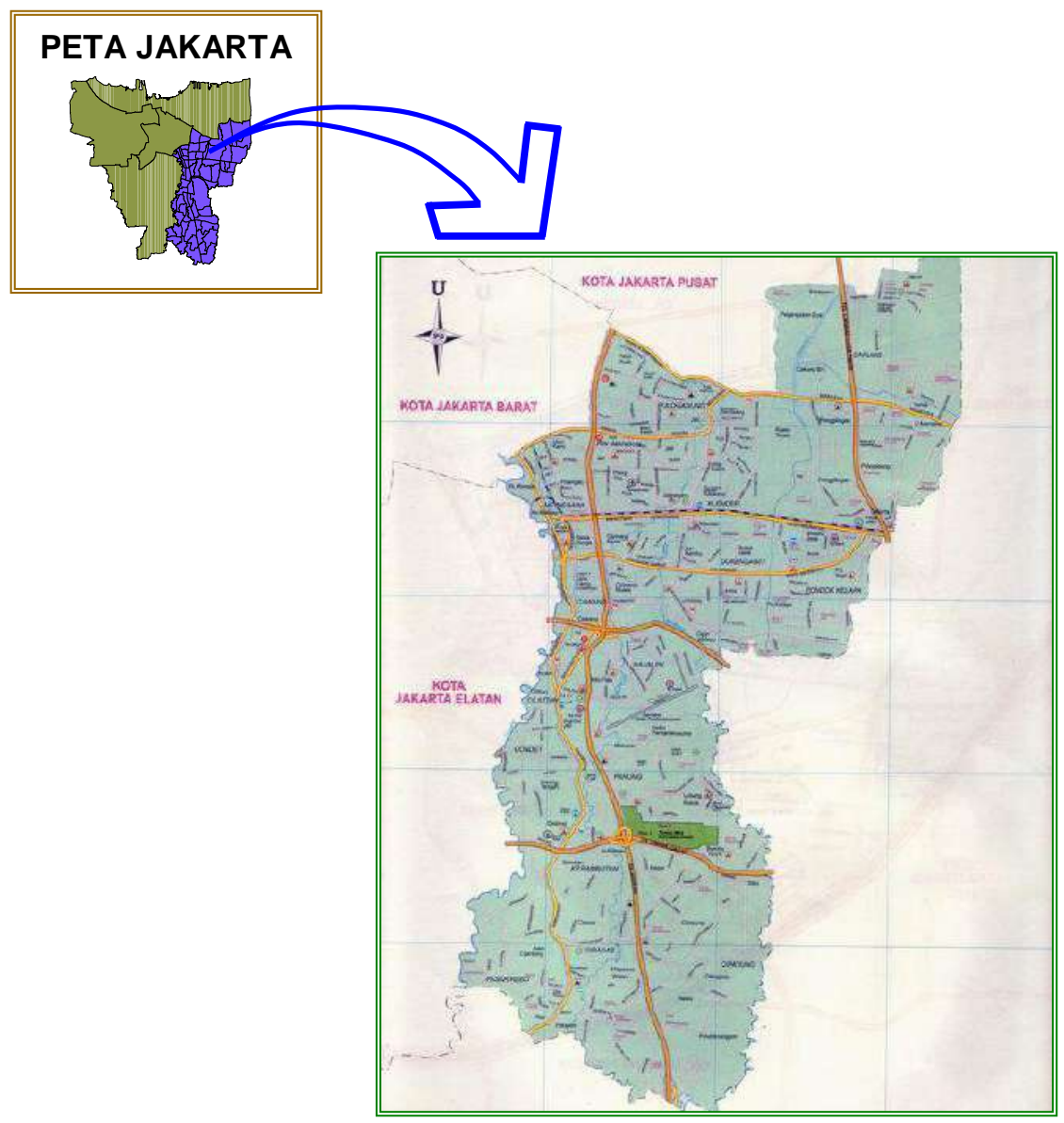

Gambar 1 Peta lokasi kegiatan studi dalam wilayah Kotamadya Jakarta Timur.

\subsection{BAHAN DAN ALAT}

\subsubsection{Bahan}

Bahan yang akan dikaji lebih lanjut akan digunakan dalam studi ini adalah data sebagai berikut: (1) Peta Rupa Bumi Digital Indonesia pada wilayah Kotamadya Jakarta Timur; (2) Landsat TM 7; (3) Data Pengelolaan Pertamanan dan Jalur Hijau Jalan Kotamadya Jakarta Timur; (4) Data Pendukung. 
Wilayah KotamadyaJakarta Timur

\subsubsection{Alat}

Pada kegiatan studi ini alat-alat yang digunakan terdiri atas 2 macam, yaitu Perangkat Lunak (software) dan Perangkat Keras (hardware). Perangkat lunak (software) digunakan sebagai alat bantu analisis didalam mengkaji dan mempermudah operasi data-data yang diperoleh di lapang, yang terdiri atas: (1) Arc View GIS versi 3.2 3D Spatial Analyst Extentions; (2) Microsoft Access; (3) Visual Basic 6; dan (4) MAPInfo.

Perangkat keras (hardware) digunakan untuk menjalankan sistem program-program dari perangkat-perangkat lunak di atas, dengan spesifikasi alat: PC Pentium P4 1800 MHz SSE Ready, DDR RAM 256 MB. Selain itu, untuk membantu di dalam inventarisasi data di lapang digunakan alat-alat yaitu: (1) Global Positioning System (GPS) Garmin Etrex Vista; (2) Kompas Suunto; (3) Kamera Digital; (4) Abney level; (5) Roll-meter.

\subsection{METODE PENGAMBILAN DATA}

Metode kegiatan survey pohon jalur hijau yang dilakukan adalah metode survei dan studi pustaka. Metode survei dilakukan dengan mengamati kondisi fisik pohon tepi jalan di Kotamadya Jakarta Timur, sedangkan studi pustaka dilakukan untuk memperoleh informasi mengenai standar pemeliharaan pohon. Secara umum penelitian dibagi dalam 4 tahap, yaitu: (1) Pengumpulan data pohon di lapang; (2) Pemetaan data pohon; (3) Pengolahan basisdata pohon; dan (4) Penyajian akhir.

\subsubsection{Pengumpulan Data Pohon di Lapang}

\subsubsection{Inventarisasi dan Pengukuran Fisik Pohon}

Inventarisasi dan pengukuran kondisi fisik pohon dilakukan pada 5 aspek yaitu: (1) Diameter batang setinggi dada atau Diameter at Breast Height (DBH); (2) Tinggi pohon; (3) Lebar tajuk; (4) Bentuk tajuk; (5) Lokasi titik tumbuh pohon.

\section{(1) Diameter batang setinggi dada atau Diameter at the Breas Height (DBH)}

Pengukuran DBH batang pohon dilakukan kurang lebih 140-145 cm dari permukaan tanah dengan menggunakan $\mathrm{DBH}$ meter. Data $\mathrm{DBH}$ yang diperoleh kemudian diklasifikasikan kedalam 4 kategori kelas tabel (Tabel 1). 
Wilayah KotamadyaJakarta Timur

Tabel 1 Tabel Kategori Kelas DBH Pohon

\begin{tabular}{ccc}
\hline Kelas & Kualifikasi & Diameter (cm) \\
\hline D1 & Semai & $\mathrm{DBH}<10$ \\
D2 & Tiang (kecil) & $10 \leq \mathrm{DBH}<30$ \\
D3 & Hampir dewasa (sedang) & $30 \leq \mathrm{DBH}<60$ \\
D4 & Dewasa (besar) & $\mathrm{DBH}>60$ \\
\hline
\end{tabular}

Sumber : Daniel, Helms, Baker (1995)

\section{(2) Tinggi Pohon}

Pengukuran tinggi pohon dengan mengggunakan Abney Level untuk memperoleh sudut bawah dan sudut atas pohon. Tinggi pohon diperoleh melalui perhitungan dengan rumus, sebagai berikut:

$$
T=(\operatorname{TAN}(\alpha)+\operatorname{TAN}(\beta))^{*} d
$$

$$
\begin{aligned}
& \text { Keterangan: } \\
& \mathrm{T}: \text { Tinggi pohon (meter) } \\
& \alpha: \text { Sudut atas }\left({ }^{\circ}\right) \\
& \beta: \text { Sudut bawah }\left({ }^{\circ}\right) \\
& \mathrm{d}: \text { Jarak pengamatan (meter) }
\end{aligned}
$$

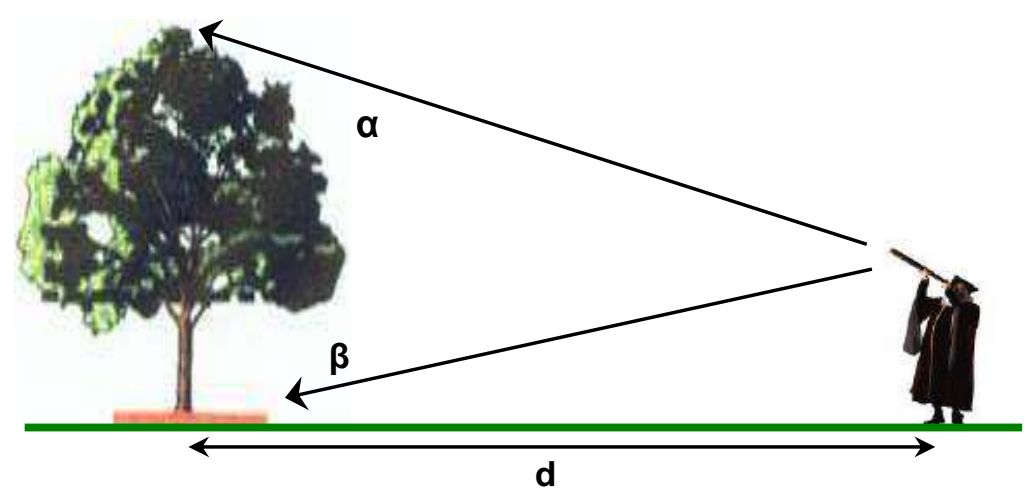

Gambar 2 Sketsa pengukuran tinggi pohon menggunakan Abney Level.

Data tinggi pohon yang diperoleh selanjutnya diklasifikasikan dalam 3 kelas seperti yang terlihat pada Tabel 2 . 
Wilayah KotamadyaJakarta Timur

Tabel 2 Kelas tinggi pohon berdasarkan karakteristiknya

\begin{tabular}{ccc}
\hline Kelas & Kualifikasi & Tinggi (m) \\
\hline 1 & Rendah & $\mathrm{T}<9$ \\
2 & Sedang & $9 \leq \mathrm{T}<18$ \\
3 & Tinggi & $\mathrm{T} \geq 18$ \\
\hline
\end{tabular}

Sumber : Carpenter, Lanphear, Walker (1975)

\section{(3) Lebar Tajuk}

Lebar tajuk diukur menggunakan rollmeter. Data lebar tajuk yang diperoleh diklasifikasikan menjadi 4 kelas (Tabel 3).

Tabel 3 Kelas lebar tajuk

\begin{tabular}{ccc}
\hline Kelas & Kualifikasi & Lebar $(\mathbf{m})$ \\
\hline L1 & Semai & $\mathrm{L}<2$ \\
L2 & Kecil & $2 \leq \mathrm{L}<5$ \\
L3 & Sedang & $5 \leq \mathrm{L}<9$ \\
L4 & Besar & $\mathrm{L} \geq 9$
\end{tabular}

Sumber : Daniel, Helms, Baker (1995)

\section{(4) Bentuk Tajuk}

Data bentuk tajuk dibagi menjadi 2 kategori yaitu simetris dan asimetris. Simetris merupakan bentuk tajuk yang sesuai dengan bentuk arsitektur tajuk pohon sedangkan asimetris adalah bentuk tajuk yang tidak sesuai dengan bentuk arsitektur tajuk pohon.

\section{(5) Lokasi Tumbuh Pohon}

Data ini diperoleh dengan menggunakan GPS (Global Positioning System). Dalam bentuk koordinat UTM $X$ dan koordinat UTM $Y$, data tersebut kemudian dipetakan pada peta rupa bumi digital.

\subsubsection{Penilaian Kondisi Fisik Pohon}

Penilaian kondisi fisik pohon didasarkan pada 3 kerusakan yaitu kerusakan hama dan penyakit tanaman, menakik, dan tehnik. Pengamatan kondisi fisik pohon dilakukan berdasarkan keadaan visual pohon dengan penekanan pada bagian pangkal akar yang berada dipermukaan tanah, batang, daun dan percabangan. 
Wilayah KotamadyaJakarta Timur

Penilaian persentase kerusakan pohon hanya berdasarkan 2 kerusakan yaitu kerusakan oleh hama/penyakit dan kerusakan mekanik. Untuk kerusakan tehnik akan diuraikan secara deskriptif berdasarkan pengamatan visual dilapang. Sistem penilaian kerusakan pohon berdasarkan sistem skoring/nilai sebagai berikut :

\section{(1) Kerusakan oleh Hama dan Penyakit}

Pengamatan kerusakan yang disebabkan hama dan penyakit tanaman dibagi menjadi 2 bagian yaitu:

a. Kerusakan hama dan penyakit pada pangkal akar di permukaan tanah dan batang (Tabel 4).

b. Kerusakan hama dan penyakit tanaman pada cabang dan daun (Tabel 5).

Tabel 4 Kerusakan hama dan penyakit tanaman pada pangkal akar dan batang

\begin{tabular}{ccc}
\hline No. & Kerusakan Hama dan Penyakit & Nilai \\
\hline 1 & Tidak ada kerusakan hama dan penyakit & 0 \\
2 & Tumbuhan tidak parasit & 1 \\
3 & Tumbuhan parasit (jamur, benalu) & 2 \\
4 & Batang kering/lapuk; Akar kering/lapuk & 3 \\
5 & Batang busuk; Akar busuk & 4 \\
6 & Gerowong/keropos yang tampak pada batang utama & 5 \\
\hline
\end{tabular}

Tabel 5 Kerusakan hama dan penyakit tanaman pada cabang dan daun

\begin{tabular}{ccc}
\hline No. & Kerusakan Hama dan Penyakit & Nilai \\
\hline 1 & Tidak ada kerusakan hama dan penyakit & 0 \\
2 & Tumbuhan tidak parasit; ulat; embun jelaga & 1 \\
3 & Tumbuhan parasit (jamur, benalu) & 2 \\
4 & Klorosis & 3 \\
5 & Nekrosis & 4 \\
6 & Percabangan lapuk & 5 \\
\hline
\end{tabular}

Untuk menghitung tingkat kerusakan karena hama dan penyakit pada pangkal akar dan batang digunakan rumus: 
Wilayah KotamadyaJakarta Timur

$$
T_{a b}=\frac{n_{i} \times 100}{\sum n_{i}}
$$

$T_{a b} \quad$ : Tingkat kerusakan hama/penyakit pada pangkal akar dan batang

$n_{i} \quad$ : Nilai

$\sum n_{i} \quad$ : Jumlah total nilai dari kerusakan hama dan penyakit pada pangkal akar dan batang

Sedangkan tingkat kerusakan hama dan penyakit pada cabang dan daun dapat dihitung dengan menggunakan rumus:

$$
T_{c d}=\frac{n_{i} \times 100}{\sum n_{i}}
$$

$T_{c d} \quad$ : Tingkat kerusakan hama/penyakit pada cabang dan daun

$n_{i} \quad$ : Nilai

$\sum n_{i} \quad$ : Jumlah total nilai dari kerusakan hama dan penyakit pada cabang dan daun

Untuk menghitung total tingkat kerusakan hama dan penyakit menggunakan rumus:

$$
T_{h p t}=\underline{T_{a b}+T_{c d}}
$$

2

$T_{\text {hpt }} \quad$ : Tingkat kerusakan oleh hama dan penyakit pohon

$T_{a b} \quad$ : Tingkat kerusakan hama dan penyakit pada pangkal akar dan batang

$T_{c d} \quad$ : Tingkat kerusakan hama dan penyakit pada cabang dan daun

Tingkat kerusakan hama dan penyakit yang telah diperoleh kemudian dikategorikan dalam peringkat sebagai berikut (Tabel 6): 
Wilayah KotamadyaJakarta Timur

Tabel 6 Tingkat kerusakan hama dan penyakit pada pohon

\begin{tabular}{ccc}
\hline No. & Kualifikasi & Serangan (\%) \\
\hline 1 & Tidak ada & $0 \leq \mathrm{T}_{\mathrm{hpt}}<15$ \\
2 & Sedikit & $15 \leq \mathrm{T}_{\mathrm{hpt}}<30$ \\
3 & Banyak & $30 \leq \mathrm{T}_{\mathrm{hpt}}<50$ \\
4 & Sangat banyak & $\mathrm{T}_{\mathrm{hpt}} \geq 50$ \\
\hline
\end{tabular}

\section{(2) Kerusakan Mekanik}

Kerusakan mekanik merupakan kerusakan pada pohon yang disebabkan oleh kontak dengan benda-benda fisik (gesekan, goresan, benturan dan sebagainya). Pengamatan yang dilakukan berdasarkan sistem nilai (Tabel 7).

Tabel 7 Kerusakan mekanik pada pohon

\begin{tabular}{ccc}
\hline No. & Kerusakan Hama dan Penyakit & Nilai \\
\hline 1 & Tidak ada kerusakan mekanik & 0 \\
2 & Coret-coret / Reklame & 1 \\
3 & Goresan & 2 \\
4 & Sayatan & 3 \\
5 & Patah cabang & 4 \\
6 & Tersambar petir & 5 \\
\hline
\end{tabular}

Selanjutnya tingkat kerusakan mekanik pada pohon dapat dihitung menggunakan rumus:

$$
T_{M}=\frac{n_{i} \times 100}{\sum n_{i}}
$$

$T_{M} \quad$ : Tingkat kerusakan mekanik pada pohon

$n_{i} \quad$ : Nilai

$\sum n_{i} \quad$ : Jumlah total nilai dari kerusakan mekanik pada pohon

Tingkat kerusakan mekanik yang diperoleh kemudian dikategorikan dalam peringkat sebagai berikut (Tabel 8): 
Wilayah KotamadyaJakarta Timur

Tabel 8 Tingkat kerusakan mekanik pada pohon

\begin{tabular}{ccc}
\hline No. & Kualifikasi & Serangan (\%) \\
\hline 1 & Tidak ada & $0 \leq \mathrm{T}_{\mathrm{m}}<15$ \\
2 & Sedikit & $15 \leq \mathrm{T}_{\mathrm{m}}<30$ \\
3 & Banyak & $30 \leq \mathrm{T}_{\mathrm{m}}<50$ \\
4 & Sangat banyak & $\mathrm{T}_{\mathrm{m}} \geq 50$ \\
\hline
\end{tabular}

Persentase kerusakan hama dan penyakit dan kerusakan mekanik kemudian digunakan untuk memperoleh tingkat kerusakan total pohon dengan menggunakan rumus:

$$
T=\underline{T_{h p t}+T_{m}}
$$

2

$T \quad$ : Total tingkat kerusakan pohon

$T_{\text {hpt }} \quad$ : Tingkat kerusakan oleh hama dan penyakit pada pohon

$T_{m} \quad$ : Tingkat kerusakan mekanik pada pohon

Data tingkat kerusakan pohon yang diperoleh kemudian dikategorikan berdasarkan peringkat sesuai dengan metode Grey dan Deneke (1978) yang telah dimodifikasi:

a. Peringkat 1 (sangat baik)

Pohon sehat dan vigor. Rata-rata serangan hama penyakit dan kerusakan mekanik $0 \% \leq \mathrm{T}<15 \%$. Sedikit atau tidak memerlukan tindakan perbaikan.

b. Peringkat 2 (baik)

Pohon cukup baik. Rata-rata serangan hama / penyakit dan kerusakan mekanik $15 \% \leq \mathrm{T}<30 \%$. Memerlukan perbaikan.

c. Peringkat 3 (buruk)

Pohon kurang baik dan kurang sehat. Rata-rata serangan hama / penyakit dan kerusakan mekanik $30 \% \leq \mathrm{T}<50 \%$. Memerlukan banyak tindakan perbaikan.

d. Peringkat 4 (sangat buruk)

Pohon dengan rata-rata serangan hama penyakit dan kerusakan mekanik $T$ $>50 \%$ atau terancam mati, atau mati. 
Wilayah KotamadyaJakarta Timur

\subsubsection{Pemetaan Data Pohon}

Data hasil pengukuran lapangan dan data dari alat GPS (Global Positioning System) dimasukkan ke dalam sebuah sistem SIG (Sistem Informasi Geografis). Data spasial untuk plotting menggunakan sistem koordinat UTM (Universal Tranverse Mercator) yang sesuai dengan koordinat peta rupa bumi digital dari BAKOSURTANAL.

Hasil yang diperoleh dari pengamatan di lapang kemudian dipetakan menggunakan software Map Info 8.0 melalui titik pohon yang diambil menggunakan GPS. Pengemasan hasil pengamatan dalam SIG ini untuk memudahkan pengguna dalam mencari informasi.

Penyajian gambar peta daerah pengelolaan Jalur Hijau Jalan dengan menggunakan titik (point) data dari survey GPS sehingga membentuk jaringan digital yang sebelumnya (GPS) tersebut telah dikonversi kedalam tipe koordinat yang diinginkan. Peta dasar digital yang sudah terbentuk digunakan sebagai background yang berfungsi sebagai referensi digital koordinat.

\subsubsection{Pengolahan Basisdata Pohon}

Pengolahan data spasial dilakukan dengan menggunakan Map Info 8.0. sedangkan pengelolaan data atribut berupa angka dan huruf dengan program MS Excel dan akhirnya ditabulasikan dengan menggunakan MS Access. Link antara Map Info 8.0 dengan MS Access, dilakukan dengan cara mengkompilasikan kedua program tersebut dalam MS Visual Basic Enterprise untuk mendapatkan tampilan yang lebih interaktif dan lebih menarik. Kompilasi tersebut akan menghasilkan file set-up yang nantinya dapat di instalkan pada masing-masing perangkat komputer (PC) pada perangkat kerja Suku Dinas Pertamanan DKI Jakarta Timur.

\subsubsection{Penyajian Hasil}

Penyajian hasil basis data informasi pengelolaan Jalur Hijau Kotamadya Jakarta Timur dalam bentuk digital dilakukan pada layar monitor (menu view) dan bentuk cetakan kertas (menu lay-out). 
Wilayah KotamadyaJakarta Timur

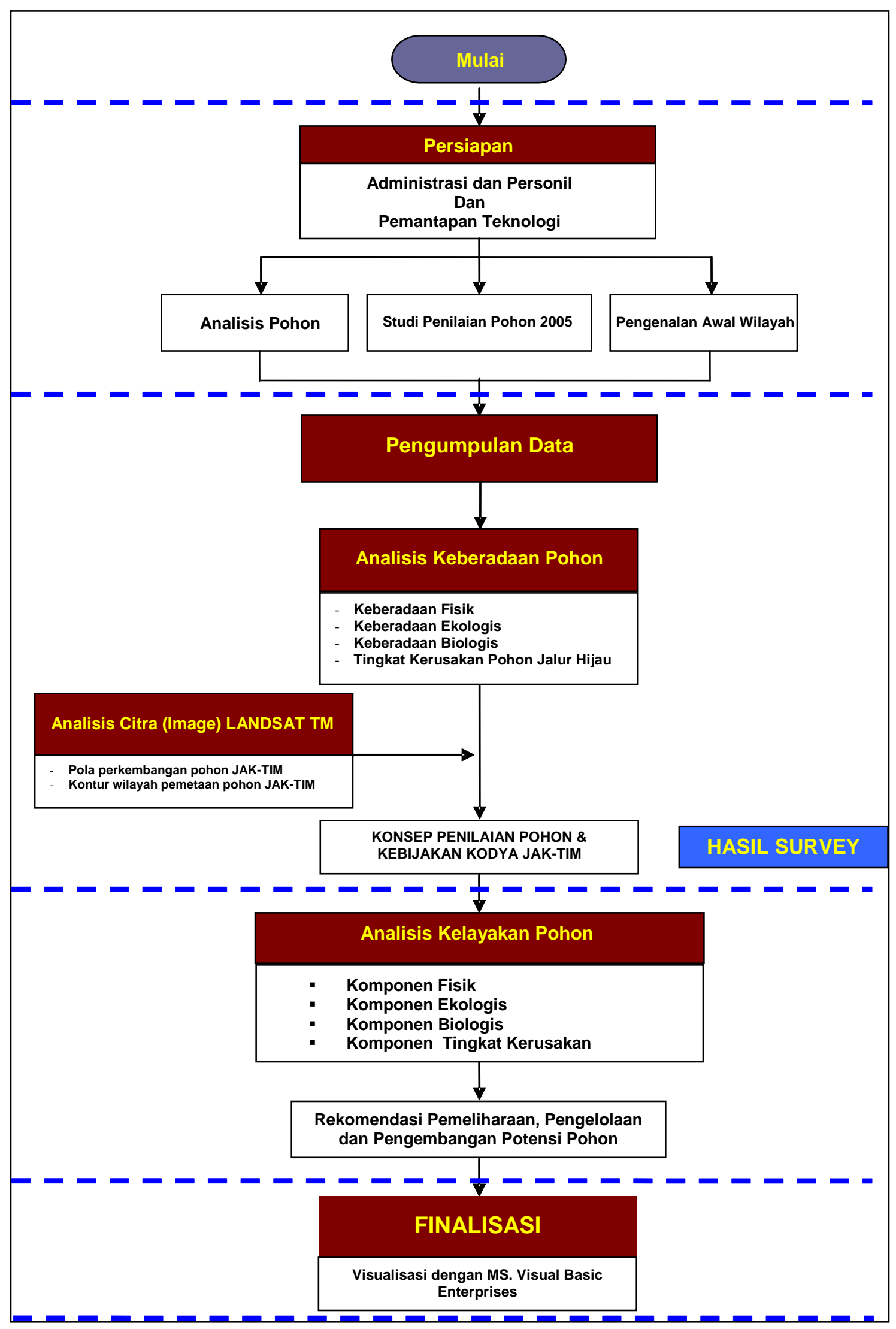

Gambar 3 Skema alur kerja kegiatan studi. 


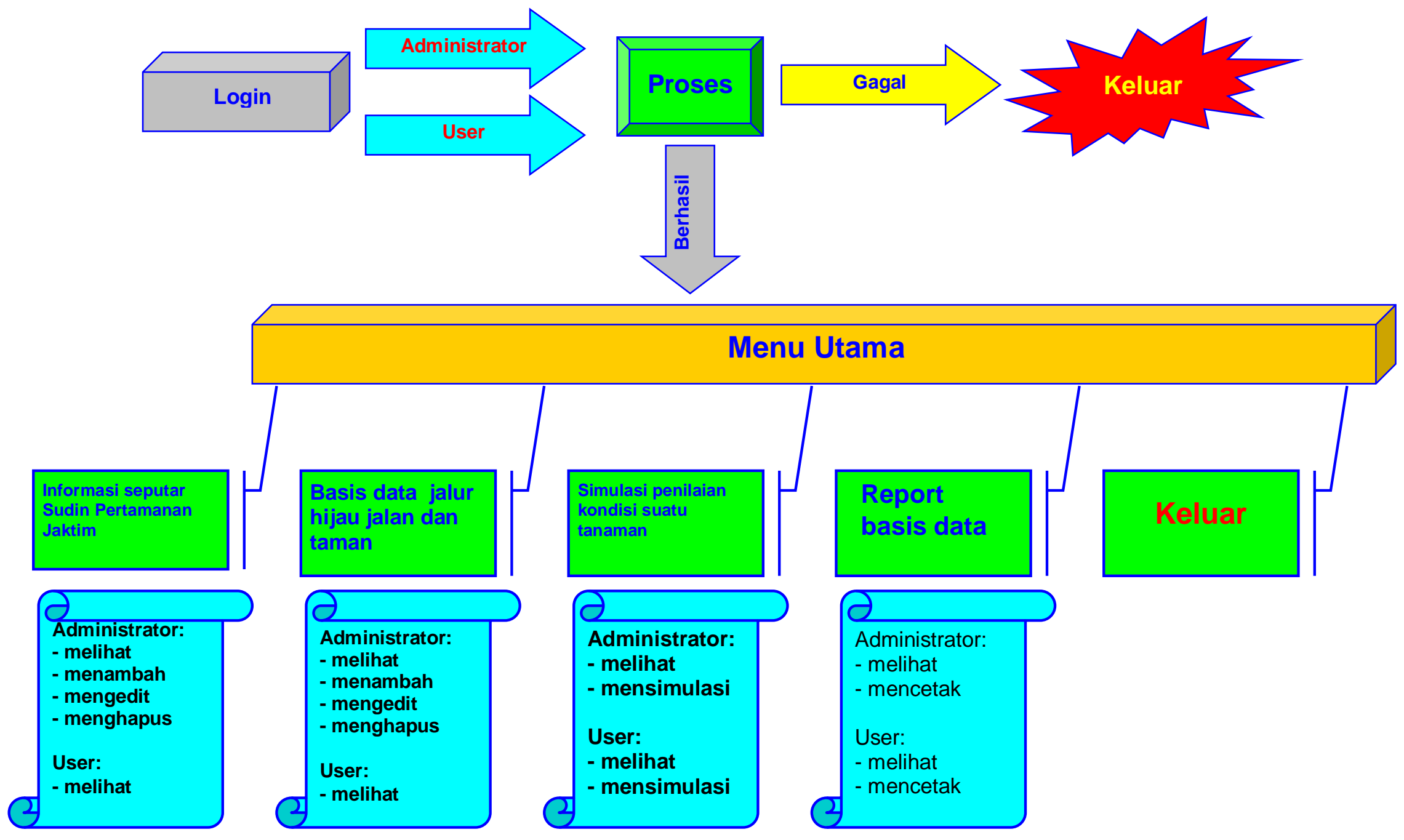

Gambar 4 Penyajian tampilan program dan struktur sistem yang dibangun. 


\section{BAB 3 \\ ANALISIS DAN HASIL KAJIAN}

Sistem Informasi Pengelolaan Ruang Terbuka Hijau ini dibuat untuk memenuhi kebutuhan akan informasi basis data mengenai sistem dan cara pengelolaan ruang terbuka hijau khususnya separator dan median jalur hijau utama, hijauan tepi jalan serta taman - taman kantong atau taman pulau jalan (vest pocket park), Kotamadya Jakarta Timur dalam format digital yang dapat diakses secara cepat.

Studi ini dilakukan pada 5 jalur hijau jalan, termasuk di dalamnya taman pulau jalan (traffic- island) dan taman tepi jalan dan 2 RTH taman yang teridentifikasi. Jalur Hijau Jalan tersebut yaitu: (1) Jalur Hijau Jalan Raya Bogor, terdiri atas sisi Barat dan Timur jalan raya; (2) Jalur Hijau Jalan Mayjen Sutoyo, terdiri atas sisi Barat dan Timur jalan raya serta bagian median jalan; (3) Jalur Hijau Jalan Jenderal Ahmad Yani, terdiri atas sisi Barat dan Timur jalan raya, sejak turunan fly-over Jatinegara hingga persimpangan antara Jalan Pemuda Pramuka (sisi Barat), serta sisi Timur jalan raya hingga persimpangan Jalan Letjen Suprapto-Perintis Kemerdekaan-Laksamana Yos Sudarso; (4) Jalur Hijau Jalan Kalimalang, terdiri atas sisi Utara dan Selatan jalan raya serta traffic-island (pulau jalan); (5) Jalur Hijau Jalan Kayu Putih Raya, terdiri atas sisi sisi Barat dan separator, sisi Timur dan separator serta median jalan. Sedangkan Ruang Terbuka Hijau (RTH) taman yang termasuk ke dalam studi ini terdiri atas 2 (dua) lokasi, yaitu: (1) Taman Hutan Kota Kompleks Perumahan karyawan Pemda DKI Pondok Kelapa, Duren Sawit, dan; (2) Taman Dermaga, Duren Sawit.

Berdasarkan hasil survey yang dilakukan di lapang, secara umum sebagian besar kondisi pohon yang terdapat jalur hijaujalan tersebut mengalami kerusakan, baik kerusakan yang disebabkan hama dan penyakit dan/atau kerusakan mekanik. Tingkat kerusakan yang dialami oleh pohon-pohon tersebut, terutama kerusakan mekanik, lebih disebabkan oleh tindakan vandalisme yang dilakukan oleh masyarakat yaitu dengan mencorat-coret, memaku, menyayat memasang reklame, mematahkan atau memotong percabangan untuk kepentingannya (berdagang, membuat rumah atau toko) dan tindakan-tindakan lainnya. Oleh karena itu perlu dilakukan tindakan-tindakan pemeliharaan yang 
Wilayah KotamadyaJakarta Timur

cukup intensif, terutama terhadap pohon-pohon yang letaknya di dalam atau berdekatan langsung dengan pusat aktifitas masyarakat, misalnya pada pasar.

\subsection{JALUR HIJAU JALAN RAYA BOGOR}

Terdiri atas sisi Barat dan Timur jalan raya, yang membentang (SelatanUtara), sejak dari turunan fly-over Pasar Rebo hingga pertigaan PGC Cililitan.

Berdasarkan hasil inventarisasi data yang dilakukan di lapang, pada sisi Barat diinventarisasi sebanyak 348 individu pohon dewasa dan pada sisi Timur sebanyak 88 individu pohon dewasa, sehingga total ada 436 pohon dewasa yang terdapat di sepanjang Jalur Hijau Jalan Raya Bogor. Individu-individu tersebut terdiri atas jenis pohon dengan spesies antara lain:
1. Angsana
8. Kapuk Randu
15. Mangga
2. Mahoni
9. Flamboyan
16. Waru
3. Asam Kranji
10. Glodogan
17. Kelapa Gading
4. Beringin
11. Akasia
18. Durian
5. Mlandingan
12. Cassia
19. Kersen
6. Kihujan
13. Walisongo
7. Jati Mas
14. Dadap Merah

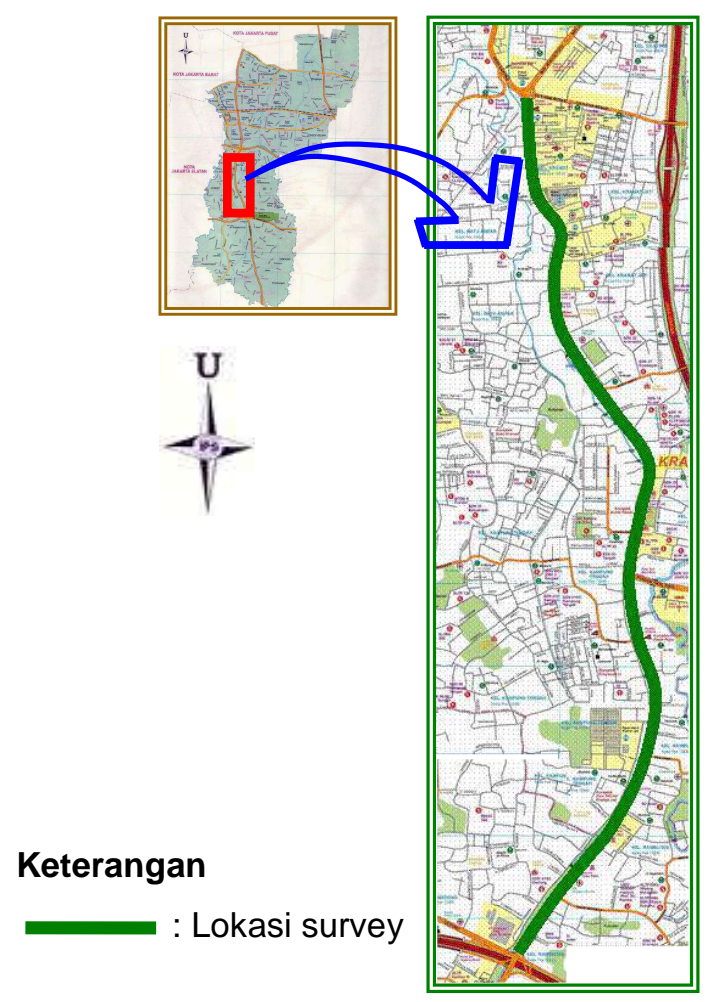

Gambar 5 Lokasi survey, Jalan Raya Bogor, membentang (Selatan-Utara) sejak dari turunan fly-over Pasar Rebo hingga pertigaan PGC Cililitan . 
Wilayah KotamadyaJakarta Timur

Secara umum kondisi pohon-pohon yang berada di sepanjang Jalan Raya Bogor ini mengalami kerusakan, baik kerusakan yang disebabkan oleh hama dan penyakit dan/atau kerusakan mekanik, dari tingkatan sedang hingga berat. Kerusakan oleh hama dan penyakit tampak pada kondisi pohon yang kering, baik pada batang, cabang maupun pada daun. Kondisi ini juga tampak pada percabangan-percabangan yang lapuk pada beberapa jenis individu pohon. Hal ini perlu mendapatkan perhatian khusus di dalam melakukan kegiatan pemeliharaan pohon, supaya tidak mengganggu aktifitas serta keselamatan masyarakat.

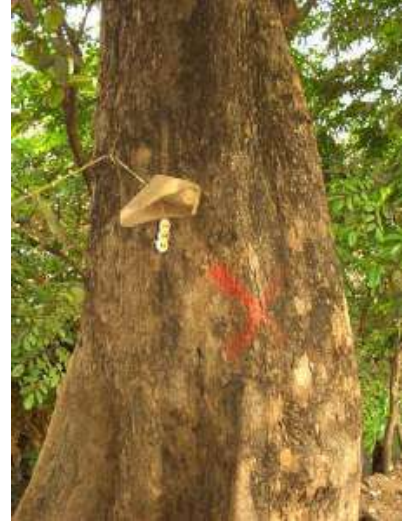

A

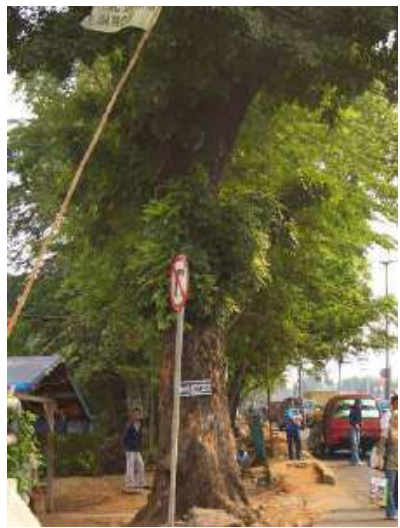

B

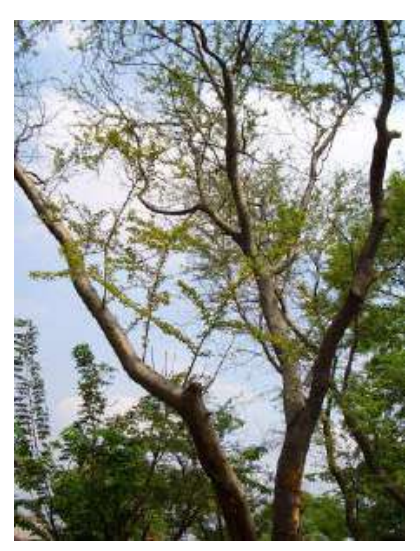

C

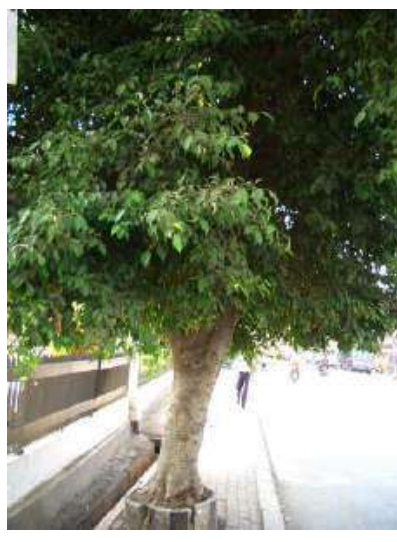

D

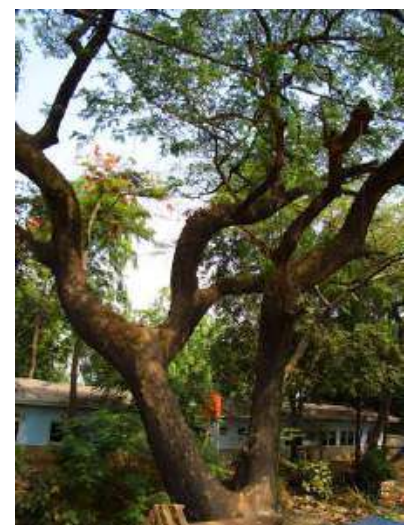

E

Gambar 6 Kondisi umum beberapa pohon di sepanjang Jalur Hijau Jalan Raya Bogor; (A) Angsana; (B) Mahoni; (C) Asam Kranji; (D) Beringin; (E) Kihujan.

Selain kerusakan yang disebabkan oleh hama dan penyakit, kerusakan mekanik juga sering ditemukan di lapang. Kerusakan mekanik yang paling sering ditemukan di lapang adalah: corat-coret atau reklame pada batang pohon, sayatan-sayatan dan goresan. Sebagai salah satu jalan utama di wilayah 
Wilayah KotamadyaJakarta Timur

Kotamadya Jakarta Timur, Jalan Raya Bogor merupakan jalur aktifitas masyarakat yang memiliki tingkat intensitas yang tinggi. Sehingga masyarakat seringkali memanfaatkan kehadiran pohon-pohon di sepanjang jalan ini untuk digunakan sebagai sarana untuk memasang reklame, berdagang ataupun untuk kegiatan lainnya. Usaha yang dapat dilakukan oleh pihak Suku Dinas Pertamanan Kotamadya Jakarta Timur antara lain melalui pengawasan serta perawatan secara rutin terhadap potensi pohon-pohon yang berada di sepanjang Jalan Raya Bogor ini, baik melalui himbauan dan pelarangan untuk merusak pohon. Hal ini dimaksudkan untuk membatasi serta meminimalisasi kerusakan-kerusakan (terutama yang disebabkan oleh masyarakat) sekaligus sebagai tindakan preventif terhadap kerusakan-kerusakan mekanik terhadap pohon.

\subsection{JALUR HIJAU JALAN MAYJEN SUTOYO}

Terdiri atas sisi Barat dan Timur jalan raya, bagian median jalan serta viaduct di sisi jalan keluar Tol Jagorawi yang mengarah ke Cawang, yang membentang (Selatan-Utara) sejak pertigaan PGC Cililitan hingga fly-over Cawang.

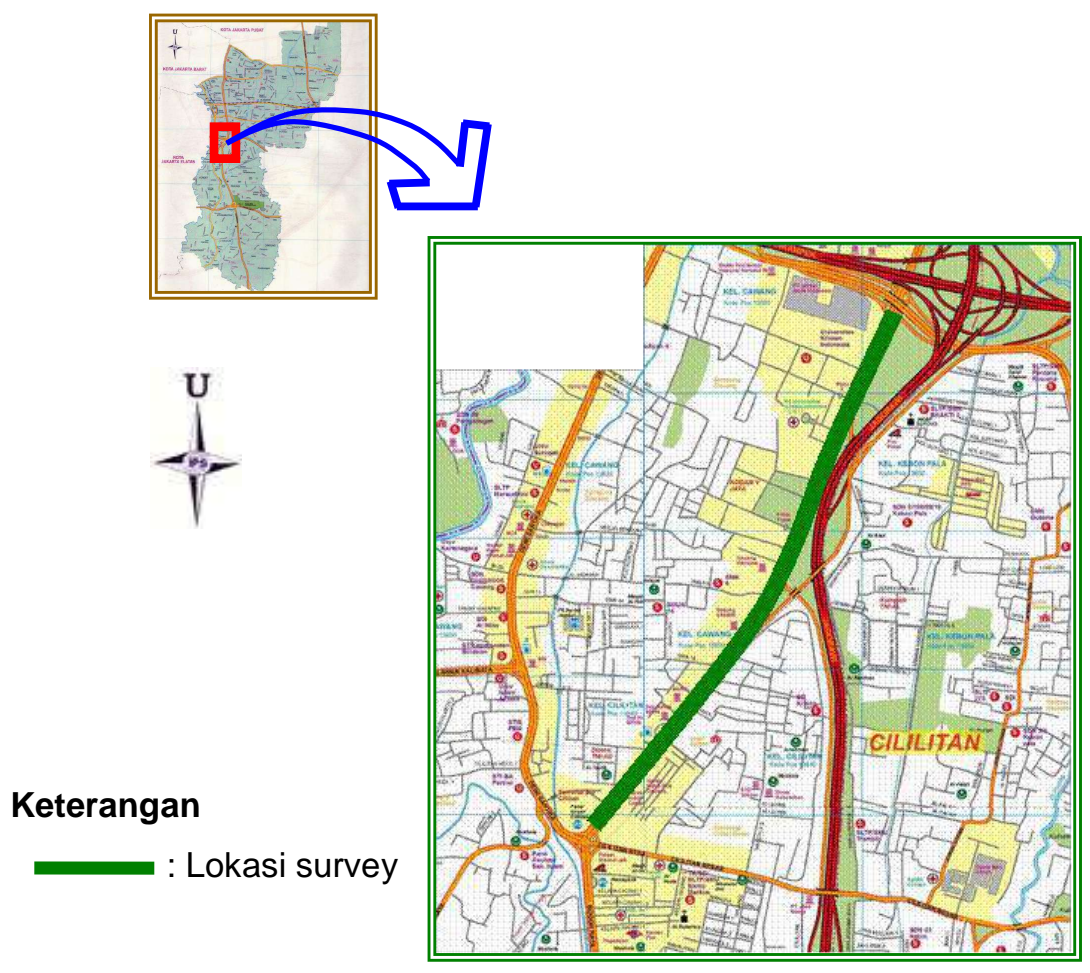

Gambar 7 Lokasi survey, Jalan Mayjen Sutoyo, membentang (Selatan-Utara) sejak pertigaan PGC Cililitan hingga fly-over Cawang. 
Wilayah KotamadyaJakarta Timur

Berdasarkan hasil inventarisasi data yang dilakukan di lapang, telah diinventarisasi sebanyak 485 individu pohon pada Jalur Hijau Jalan Mayjen Sutoyo, yang terdiri atas: 90 individu pohon pada sisi Barat; 123 pohon pada jalur median; 181 pohon pada sisi Timur, dan; sebanyak 91 individu pohon pada viaduct. Individu-individu tersebut terdiri atas jenis pohon dengan spesies antara lain:
1. Angsana
8. Kersen
15. Kihujan/Trembesi
2. Mahoni
9. Asam Kranji
16. Pinus
3. Jati Mas
10. Cassia
17. Dadap Merah
4. Beringin
11. Flamboyan
5. Kapuk Randu
12. Tanjung
6. Glodogan
13. Nangka
7. Akasia
14. Bunga Kupu-kupu

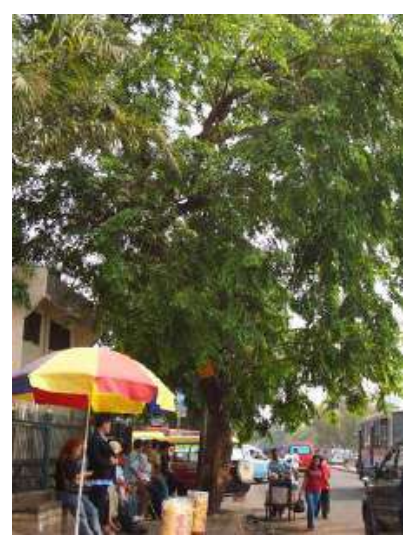

A

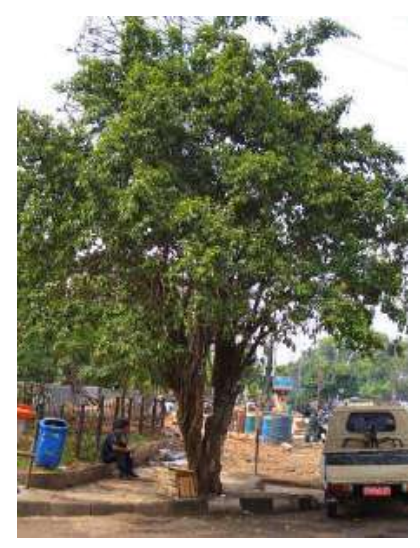

D

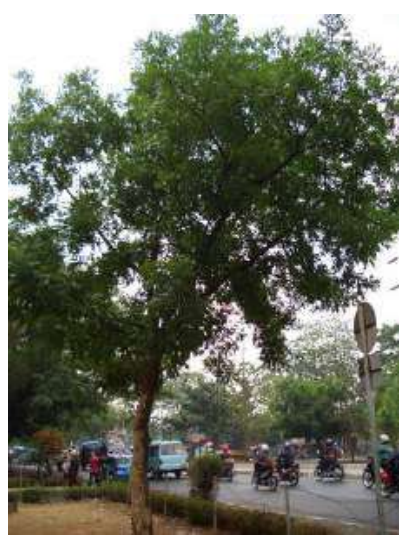

B

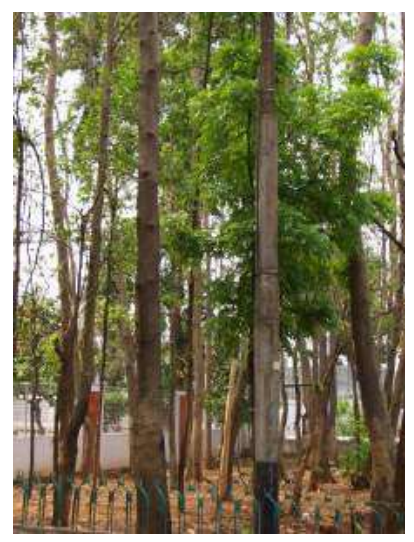

C

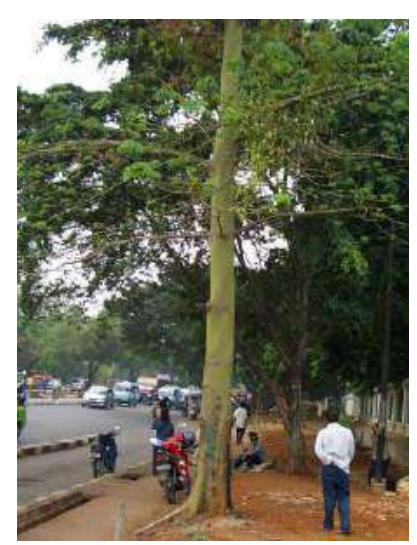

E

Gambar 8 Kondisi Umum Beberapa Pohon di Sepanjang Jalur Hijau Jalan Mayjen Sutoyo; (A) Angsana; (B) Mahoni; (C) Jati Mas; (D) Beringin; (E) Kapuk Randu. 
Wilayah KotamadyaJakarta Timur

Seperti kondisi pohon-pohon pada Jalan Raya Bogor, pohon-pohon yang berada di sepanjang Jalan Mayjen Sutoyo ini juga mengalami kerusakan, baik kerusakan yang disebabkan oleh hama dan penyakit dan/atau kerusakan mekanik, dengan berbagai tingkatan. Kerusakan oleh hama dan penyakit tampak pada kondisi pohon yang kering, baik pada batang, cabang maupun pada daun. Kondisi ini juga tampak pada percabangan-percabangan yang lapuk pada beberapa jenis individu pohon.

\subsection{JALUR HIJAU JALAN JENDERAL AHMAD YANI}

Terdiri atas sisi Barat dan Timur jalan raya, yang membentang (SelatanUtara) sejak turunan fly-over Jatinegara hingga persimpangan antara Jalan Pemuda - Pramuka, (pada sisi Barat) serta sisi Timur jalan raya hingga persimpangan Jalan Letjen Suprapto-Perintis Kemerdekaan-Laksamana Yos Sudarso.

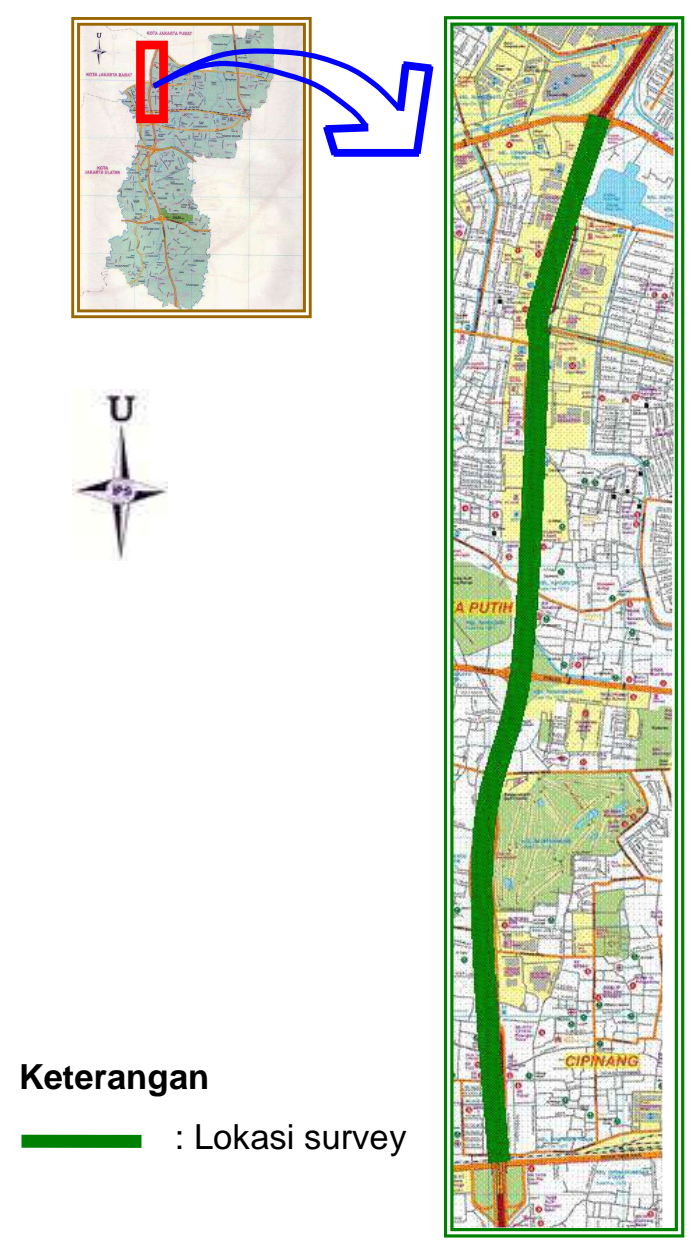

Gambar 9 Lokasi survey, Jalan Jenderal Ahmad Yani, membentang (SelatanUtara) sejak turunan fly-over Jatinegara hingga persimpangan Jalan Letjen Suprapto-Perintis Kemerdekaan-Laksamana Yos Sudarso. 
Wilayah KotamadyaJakarta Timur

Berdasarkan hasil inventarisasi data yang dilakukan di lapang, diinventarisasi sebanyak $\mathbf{8 8 2}$ individu pohon pada Jalur Hijau Jalan Jenderal Ahmad Yani, yang terdiri atas: 299 individu pohon pada sisi Barat, 523 pohon pada sisi Timur. Individu-individu tersebut terdiri atas jenis pohon dengan spesies antara lain:
1. Angsana
6. Beringin
11. Palem Raja
2. Glodogan Tiang
7. Tanjung
12. Ketapang
3. Glodogan
8. Bintaro
13. Flamboyan
4. Akasia
9. Dadap Merah
14. Kapuk Randu
5. Mahoni
10. Lamtoro
15. Jati Mas

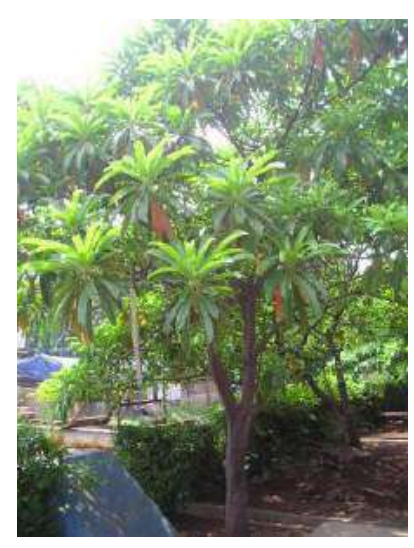

A

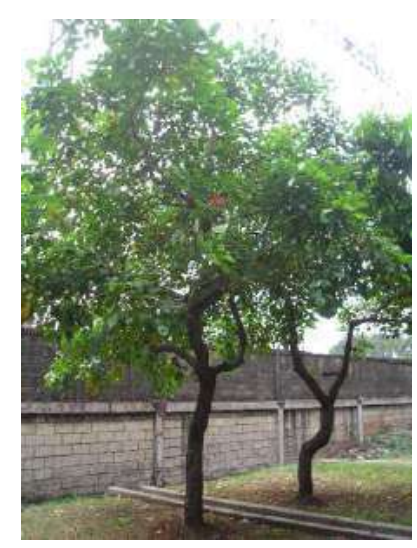

B

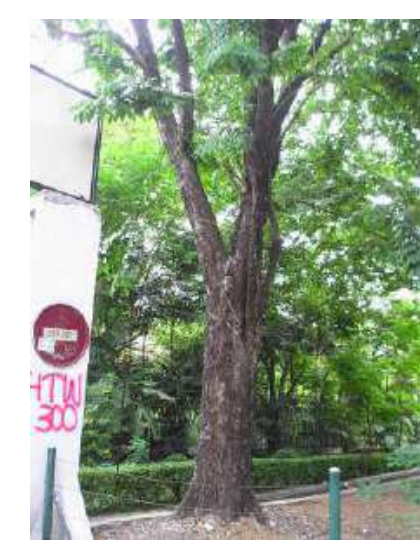

C

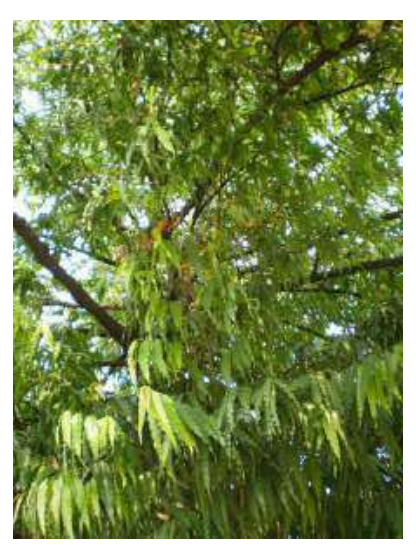

D

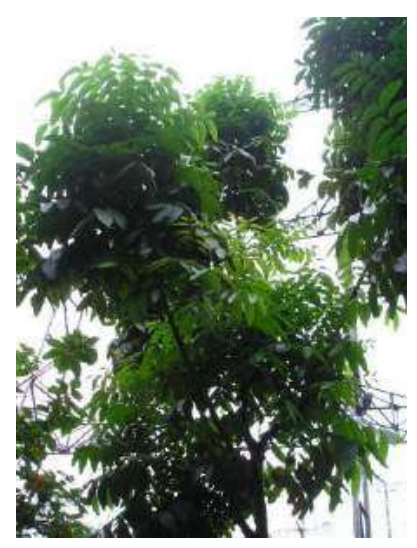

E

Gambar 10 Kondisi umum beberapa pohon di sepanjang Jalur Hijau Jalan Jenderal Ahmad Yani; (A) Bintaro; (B) Dadap Merah; (C) Angsana; (D) Glodogan; (E) Mahoni.

Secara umum kondisi pohon-pohon yang berada di sepanjang Jalur Hijau Jalan Jenderal Ahmad Yani ini mengalami kerusakan, baik kerusakan yang disebabkan oleh hama dan penyakit dan/atau kerusakan mekanik. Kerusakan 
oleh hama dan penyakit tampak pada kondisi pohon yang kering, baik pada batang, cabang maupun pada daun. Kondisi ini juga tampak pada percabanganpercabangan yang lapuk pada beberapa jenis individu pohon. Hal ini perlu mendapatkan perhatian khusus di dalam melakukan kegiatan pemeliharaan pohon.

Selain kerusakan yang disebabkan oleh hama dan penyakit, kerusakan mekanik juga sering ditemukan di lapang. Kerusakan mekanik yang paling sering ditemukan di lapang adalah: corat-coret atau reklame pada batang pohon, sayatan-sayatan dan goresan. Masyarakat seringkali memanfaatkan kehadiran pohon-pohon di sepanjang jalan ini untuk digunakan sebagai sarana untuk memasang reklame, berdagang ataupun untuk kegiatan lainnya. Usaha yang dapat dilakukan oleh pihak Suku Dinas Pertamanan Kotamadya Jakarta Timur antara lain melalui pengawasan serta perawatan secara rutin terhadap potensi pohon-pohon yang berada di sepanjang Jalur Hijau Jalan Ahmad Yani ini, baik melalui himbauan dan pelarangan untuk merusak pohon. Hal ini dimaksudkan untuk membatasi serta meminimalisasi kerusakan-kerusakan (terutama yang disebabkan oleh masyarakat) sekaligus sebagai tindakan preventif terhadap kerusakan-kerusakan mekanik terhadap pohon.

\subsection{JALUR HIJAU JALAN RAYA KALIMALANG}

Terdiri atas sisi Utara dan Selatan jalan raya serta traffic-island (pulau jalan), yang membentang (Barat-Timur) sejak Kalimalang Cipinang Muara hingga Pasar Sumber Artha.

Hasil survey yang dilakukan di lapang, diinventarisasi sebanyak 842 individu pohon pada Jalur Hijau Jalan Raya Kalimalang, yang terdiri atas: 255 individu pohon pada sisi Utara, dan 587 pohon pada sisi Selatan. Individuindividu tersebut terdiri atas jenis pohon dengan spesies antara lain:
1. Angsana
5. Kapuk Randu
9. Asam Kranji
2. Kayu Putih
6. Flamboyan
10. Cassia
3. Beringin
7. Akasia
11. Jaranan
4. Mlandingan
8. Beringin Laut
12. Dadap

Secara umum pohon-pohon yang berada di sepanjang Jalan Raya Kalimalang didominasi oleh pohon jenis Angsana (Pterocarpus indicus). Pohon jenis ini meskipun memiliki kemampuan tumbuh yang cepat, tetapi memiliki karakteristik batang dan percabangan yang getas (mudah patah), terutama 
apabila terjadi hujan lebat yang disertai angin. Oleh karena itu, perlu mendapatkan perhatian sekaligus tindakan pengelolaan yang baik dan rutin, dalam rangka menjaga kelangsungan tumbuh pohon jenis ini.
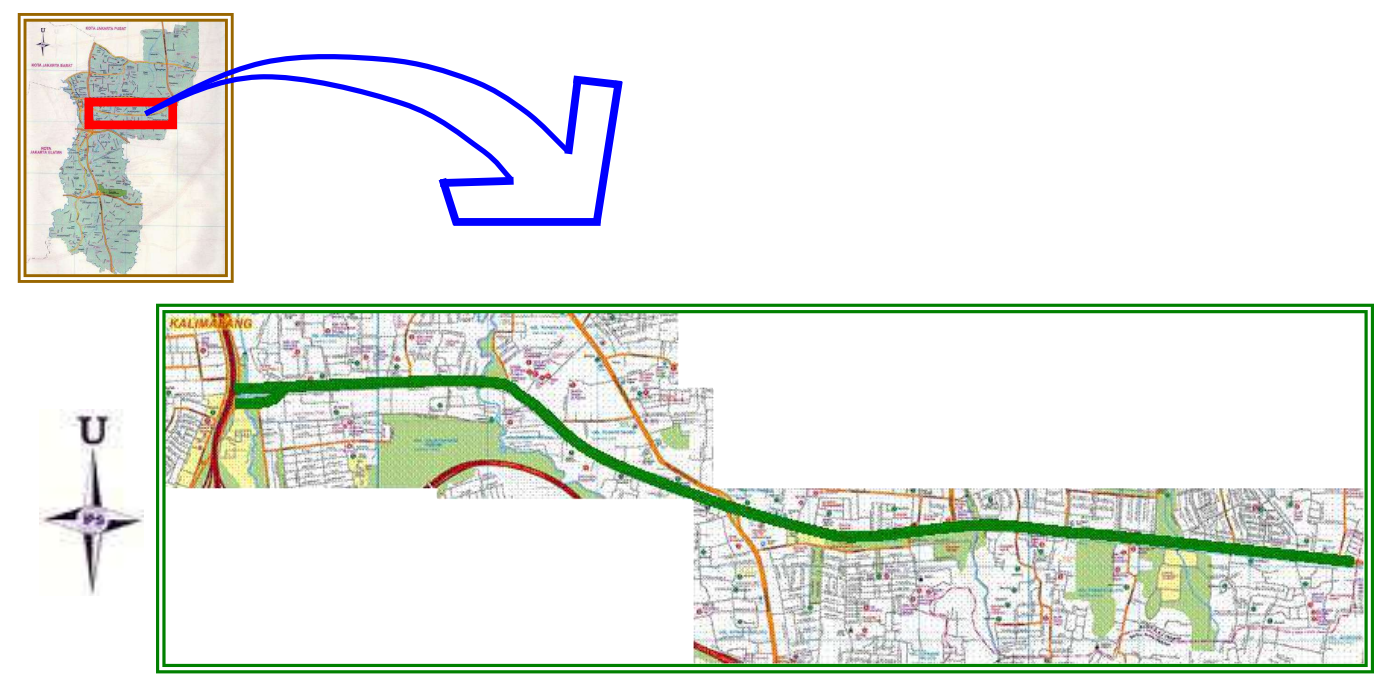

Keterangan

: Lokasi survey

Gambar 11 Lokasi survey, Jalan Raya Kalimalang, membentang (Barat-Timur) sejak Kalimalang Cipinang Muara hingga Pasar Sumber Artha.

Selain hal tersebut, kondisi pohon-pohon di sepanjang Jalan Raya Kalimalang juga mengalami kerusakan, baik kerusakan oleh hama dan penyakit dan/atau kerusakan mekanik. Kerusakan oleh hama dan penyakit tampak pada kondisi pohon yang kering, baik pada batang, cabang maupun pada daun, bahkan pada beberapa pohon mengalami gerowong pada pangkal batang. Sedangkan pada beberapa pohon tampak percabangan-percabangan yang lapuk. Hal ini perlu mendapatkan perhatian khusus di dalam melakukan kegiatan pemeliharaan pohon, supaya tidak mengganggu aktifitas serta keselamatan masyarakat.

Kerusakan mekanik yang paling sering ditemukan di lapang adalah: corat-coret atau reklame pada batang pohon, sayatan-sayatan dan goresan. Jalan Raya Kalimalang merupakan salah satu jalur aktifitas masyarakat yang memiliki tingkat intensitas sangat tinggi. Sehingga masyarakat seringkali memanfaatkan kehadiran pohon-pohon di sepanjang jalan ini untuk digunakan sebagai sarana untuk memasang reklame, berdagang ataupun untuk kegiatan lainnya. Usaha yang dapat dilakukan oleh pihak Suku Dinas Pertamanan 
Wilayah KotamadyaJakarta Timur

Kotamadya Jakarta Timur antara lain melalui pengawasan serta perawatan secara rutin terhadap potensi pohon-pohon yang berada di sepanjang Jalan Raya Kalimalang ini. Hal ini dimaksudkan untuk membatasi serta meminimalisasi kerusakan-kerusakan (terutama yang disebabkan oleh masyarakat) sekaligus sebagai tindakan preventif terhadap kerusakan-kerusakan mekanik terhadap pohon.
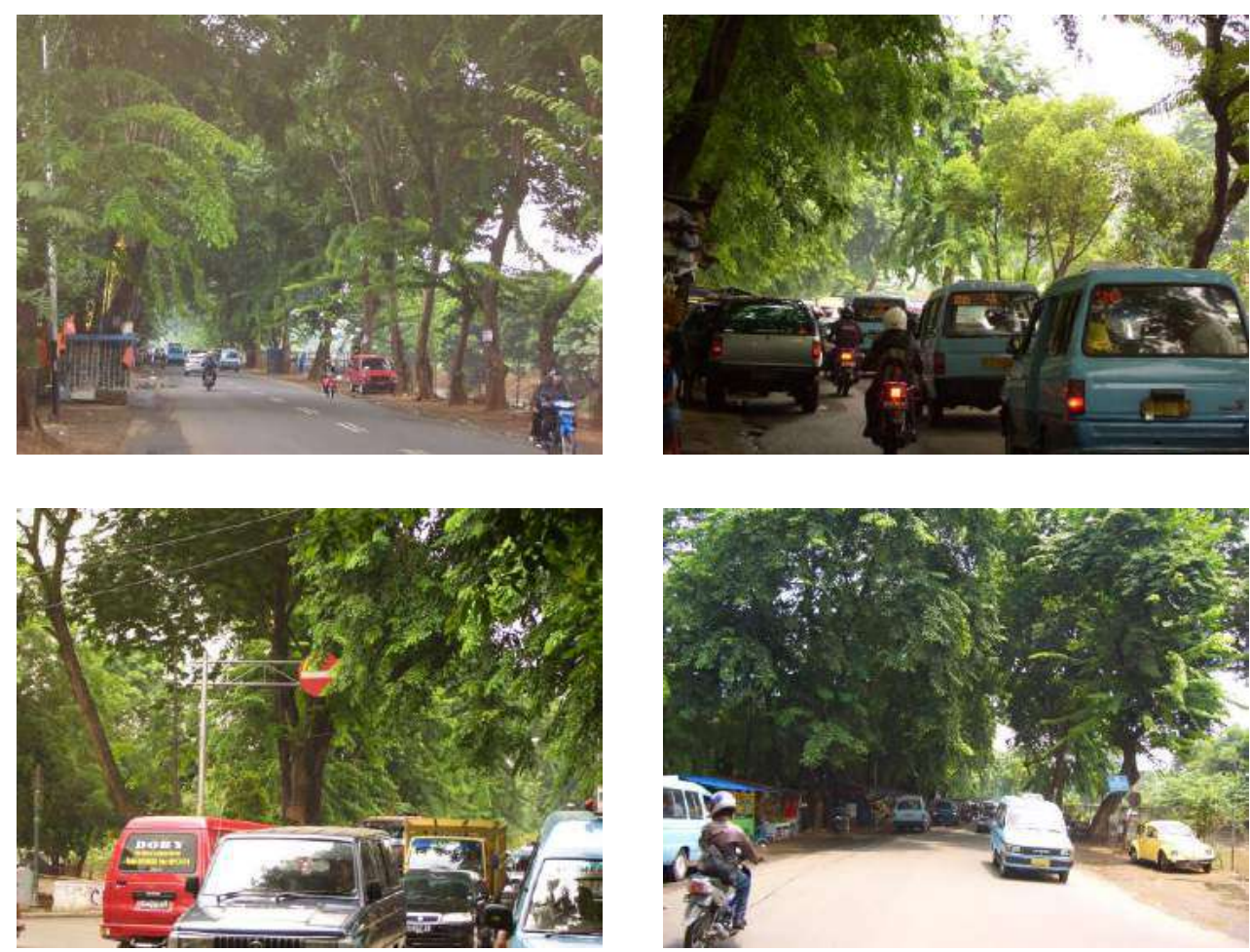

Gambar 12 Kondisi umum beberapa pohon di sepanjang Jalur Hijau Jalan Raya Kalimalang.

\subsection{JALUR HIJAU JALAN KAYU PUTIH RAYA}

Terdiri atas sisi sisi Barat dan separatornya, sisi Timur dan separatornya serta median jalan, membentang (Selatan-Utara) sejak persimpangan Jalan Tanah Mas Kayu Putih hingga persimpangan antara Jalan Perintis Kemerdekaan.

Survey yang dilakukan di lapang mengidentifikasi sebanyak 427 individu pohon pada Jalur Hijau Jalan Kayu Putih Raya, yang terdiri atas: 51 individu pohon pada sisi Barat; 42 pohon pada sisi Separator Barat; 131 ppohon pada sisi Median Jalan; 168 pohon pada sisi Separator Timur, dan; sebanyak 35 pohon pada sisi sebelah Timur. Individu-individu tersebut terdiri atas jenis pohon dengan spesies antara lain: 
Wilayah KotamadyaJakarta Timur
1. Cemara Angin
6. Mahoni
11. Tanjung
2. Angsana
7. Bunga Kupu-kupu
12. Nangka
3. Palem Raja
8. Mlandingan
13. Sikat Botol
4. Kayu Putih
9. Ketapang
5. Beringin
10. Glodogan

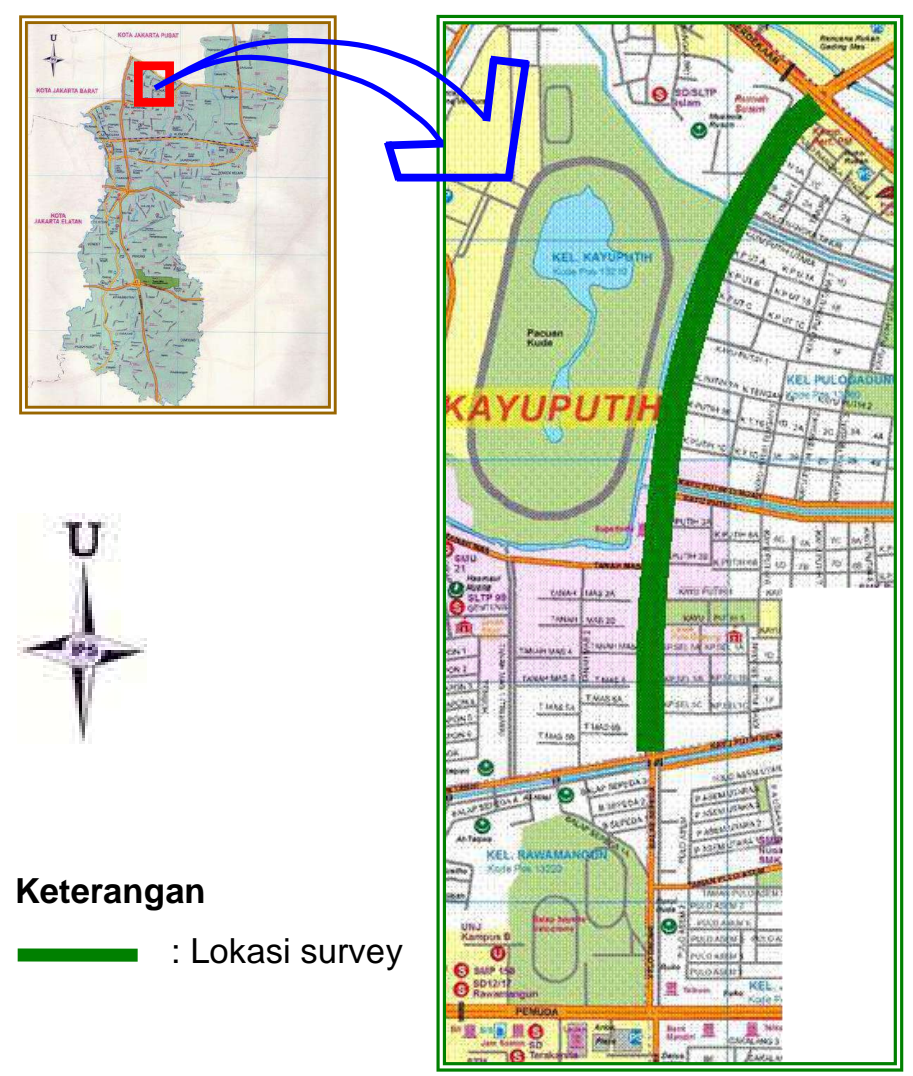

Gambar 13 Lokasi survey, Jalan Kayu Putih Raya, membentang (Selatan-Utara) sejak persimpangan Jalan Tanah Mas Kayu Putih hingga persimpangan antara Jalan Perintis Kemerdekaan.

Secara umum pohon-pohon yang berada di sepanjang Jalan Kayu Putih Raya ini didominasi oleh pohon dengan jenis Cemara Angin, terutama pada bagian sisi separator, baik Separator Barat maupun Separator Timur. Sebenarnya pohon jenis ini memiliki fungsi ekologi yang cukup baik, terutama dalam menciptakan kenyamanan iklim mikro di sekitar lingkungan tempat tumbuh pohon ini. Tetapi dengan tingkat kepadatan lalu-lintas sangat tinggi pada lokasi ini, yang menghasilkan polusi dalam jumlah yang banyak serta tidak ditunjang dengan kondisi media tumbuh yang baik (seperti kondisi tanah, ruang tumbuh, perawatan dan pemeliharaan rutin) menjadikan pohon-pohon Cemara Angin di sepanjang Jalan Kayu Putih Raya ini terlihat gersang. 
Wilayah KotamadyaJakarta Timur

Hal ini tampak pada kondisi batang dan percabangan yang tampak kering. Kondisi ini dapat membahayakan para pengguna jalan dan masyarakat sekitar, apabila terjadi hujan deras dan disertai angin maka percabangan atau bahkan pohon itu sendiri rawan terjadi tumbang. Hal ini perlu mendapatkan perhatian khusus oleh pihak Suku Dinas Pertamanan Kotamadya Jakarta Timur untuk melakukan kegiatan pemeliharaan pohon, terutama dalam hal pemangkasan (baik pucuk maupun tajuk) dan pemupukan serta pemberantasan hama dan penyakit tanaman, supaya tidak terjadi hal-hal yang mengganggu aktifitas serta keselamatan masyarakat.
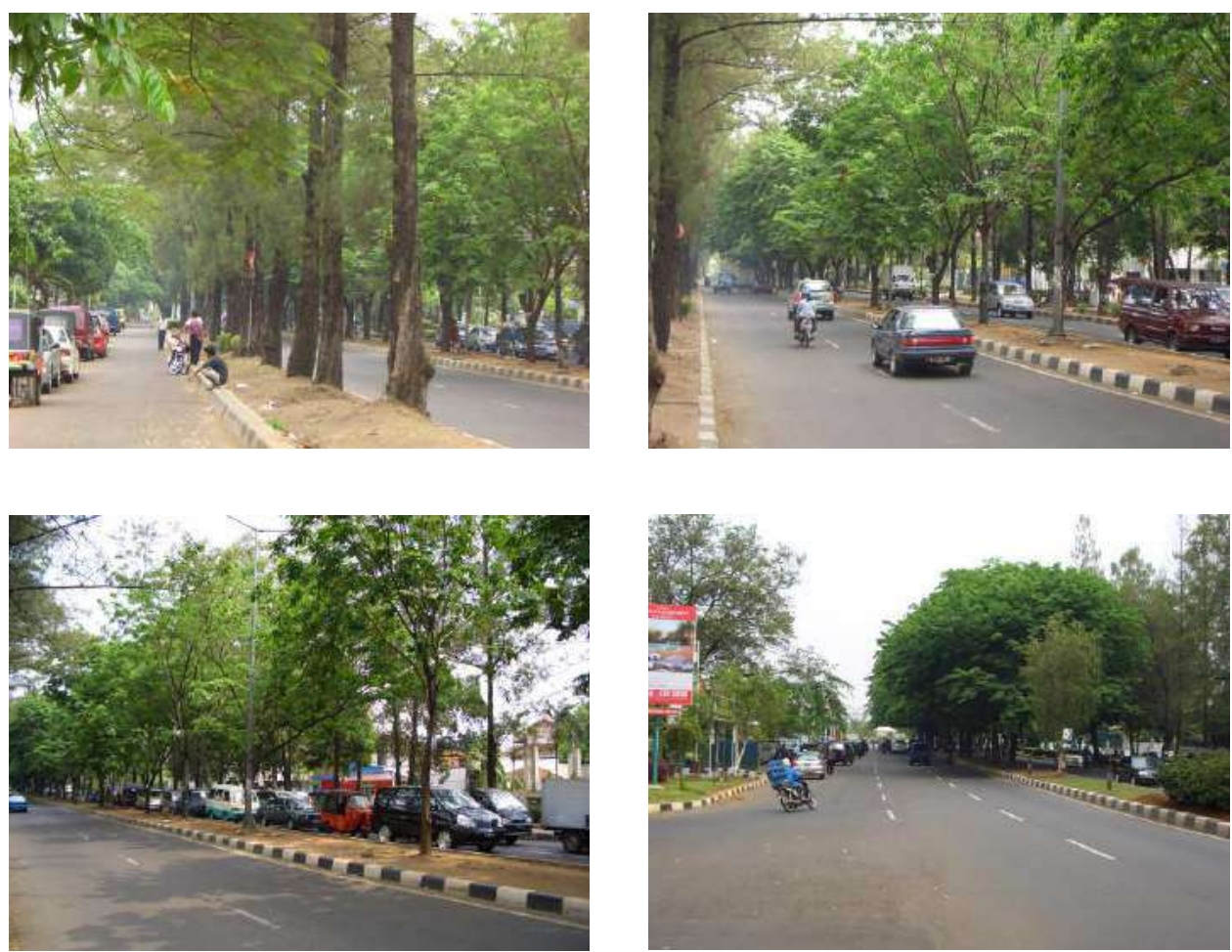

Gambar 14 Kondisi Umum Beberapa Pohon di Sepanjang Jalur Hijau Jalan Kayu Putih Raya.

Sedangkan kerusakan mekanik yang sering ditemukan di lapang adalah: corat-coret atau reklame pada batang pohon, sayatan-sayatan dan goresan. Usaha yang dapat dilakukan oleh pihak Suku Dinas Pertamanan Kotamadya Jakarta Timur yaitu antara lain melalui pengawasan serta perawatan secara rutin terhadap potensi pohon-pohon yang berada di sepanjang Jalan Kayu Putih Raya ini, baik melalui himbauan dan pelarangan untuk merusak pohon. Hal ini dimaksudkan untuk membatasi serta meminimalisasi kerusakan-kerusakan 
Wilayah KotamadyaJakarta Timur

(terutama yang disebabkan oleh masyarakat) sekaligus sebagai tindakan preventif terhadap kerusakan-kerusakan mekanik terhadap pohon.

\subsection{RUANG TERBUKA HIJAU (RTH) KELOMPOK TAMAN DERMAGA, DUREN SAWIT RAYA}

Lokasi Ruang Terbuka Hijau (RTH) Taman Dermaga ini berada di Jalan Duren Sawit Raya, Kecamatan Duren Sawit. Pada survey ini diinventarisasi sebanyak 11 RTH Taman yang tersebar di lokasi ini. Masing-masing RTH Taman memiliki variasi luasan yang berbeda-beda, tetapi rata-rata luasan RTH Taman tersebut berkisar antara $200 \mathrm{~m}^{2}-500 \mathrm{~m}^{2}$ (bahkan terdapat RTH Taman dengan luasan kurang dari $100 \mathrm{~m}^{2}$ ).

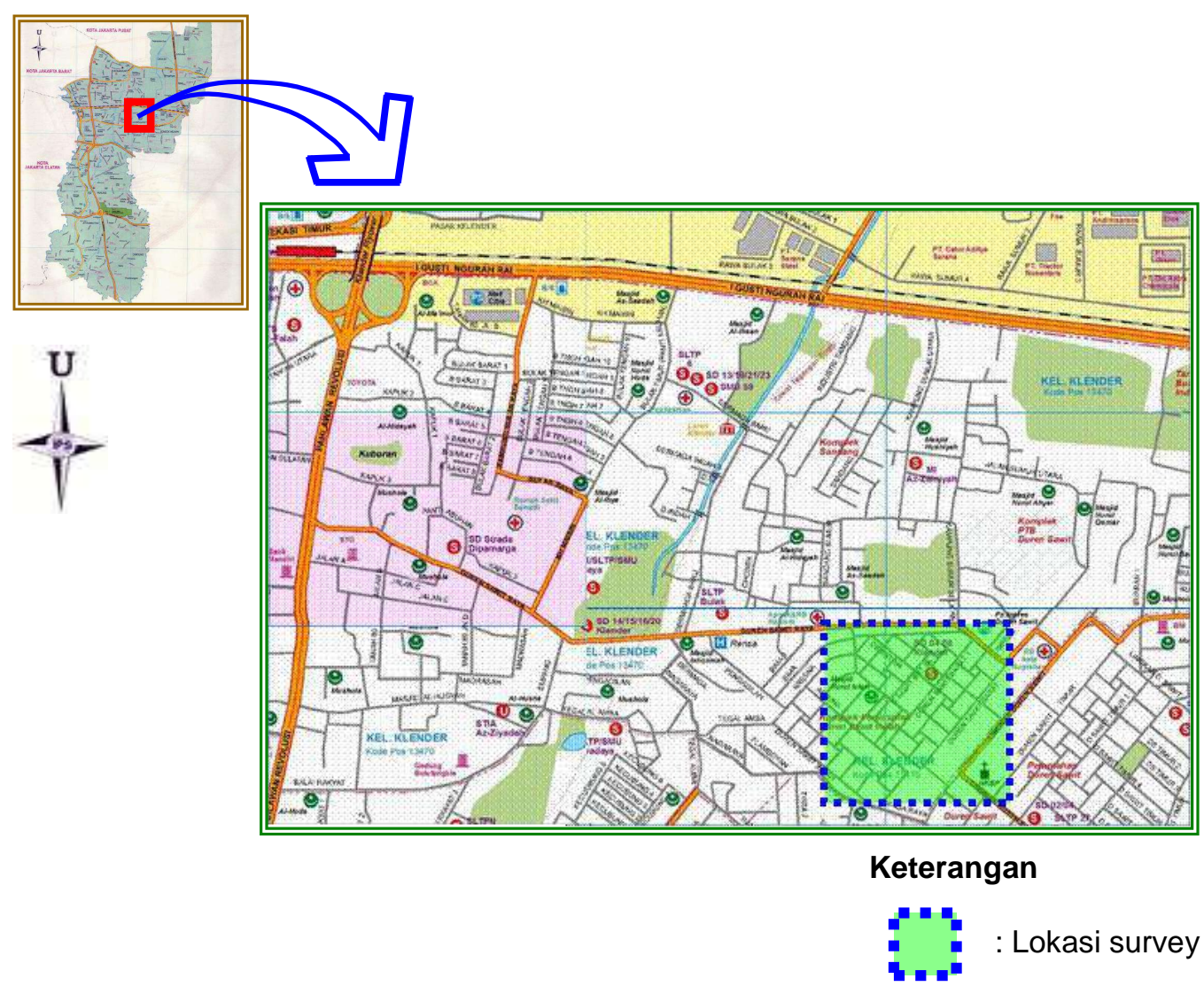

Gambar 15 Lokasi survey, kelompok Taman Dermaga, Jalan Duren Sawit Raya.

Survey yang dilakukan di lapang, pada $11 \mathrm{RTH}$ Taman tersebut teridentifikasi sebanyak 187 individu pohon. Individu-individu tersebut terdiri atas jenis pohon dengan spesies antara lain: 
Wilayah KotamadyaJakarta Timur

$\begin{array}{lll}\text { 1. Angsana } & \text { 8. Bunga Kupu-kupu } & \text { 15. Kersen } \\ \text { 2. Mahoni } & \text { 9. Kayu Putih } & \text { 16. Sawo } \\ \text { 3. Palem Raja } & \text { 10. Mangga } & \text { 17. Salak } \\ \text { 4. Kelapa Gading } & \text { 11. Flamboyan } & \text { 18. Dadap Merah } \\ \text { 5. Beringin } & \text { 12. Mlandingan } & \text { 19. Cassia } \\ \text { 6. Tanjung } & \text { 13. Glodogan Tiang } & \text { 20. Palem Putri } \\ \text { 7. Akasia } & \text { 14. Nangka } & \text { 21. Mindi }\end{array}$

Secara umum kondisi pohon-pohon yang berada di dalam kompleks RTH Taman Dermaga ini mengalami kerusakan, terutama kerusakan mekanik, dari tingkatan sedang hingga berat. Kerusakan mekanik yang paling sering ditemukan di lapang adalah: corat-coret pada batang pohon, sayatan-sayatan dan goresan, bahkan patah cabang. Interaksi antar komunitas yang diharapkan terjadi di dalam taman, lebih mengarah pada tindakan-tindakan yang negatif, cenderung vandalisme. Hal ini tampak pada sayatan maupun goresan yang dominan terlihat pada tiap-tiap individu pohon tersebut. Selain tindakan tersebut, terlihat dengan jelas pula sampah yang berserakan dan tidak dibuang pada tempatnya.
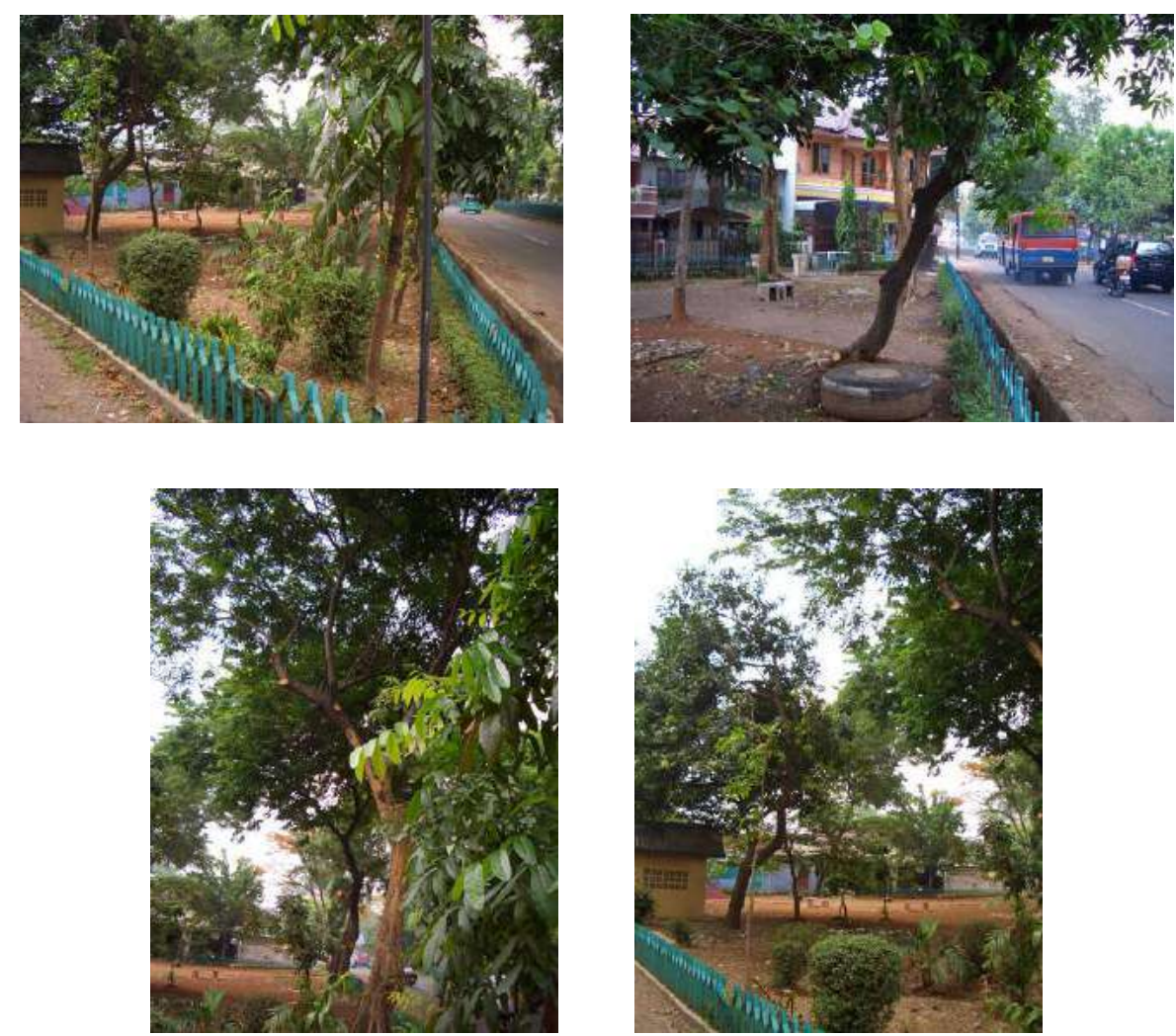

Gambar 16 Kondisi umum beberapa pohon di Kelompok Taman Dermaga, Duren Sawit Raya. 
Wilayah KotamadyaJakarta Timur

Oleh karena itu, tindakan yang perlu dilakukan oleh Sudin Pertamanan Kotamadya Jakarta Timur sebagai pengelola RTH Taman tersebut akan lebih baik apabila difokuskan kepada pengorganisasian dan pengelolaan yang baik sekaligus rutin terhadap RTH Taman tersebut. Himbauan dan pelarangan untuk merusak pohon di dalam taman perlu untuk terus dilakukan dan kotinu. Hal ini dimaksudkan untuk membatasi serta meminimalisasi kerusakan-kerusakan (terutama yang disebabkan oleh masyarakat) sekaligus sebagai tindakan preventif terhadap kerusakan-kerusakan mekanik terhadap pohon.

\subsection{RUANG TERBUKA HIJAU (RTH) TAMAN HUTAN KOTA, PERUM KARYAWAN PEMDA DKI, PONDOK KELAPA}

Lokasi Ruang Terbuka Hijau (RTH) Taman Hutan Kota, Perum Karyawan Pemda DKI ini berada di Jalan H. Dogol, Pondok Kelapa Raya. Total luas area Ruang Terbuka Hijau (RTH) Taman ini yaitu $20.000 \mathrm{~m}^{2}$ (2 Ha). Taman ini terdiri atas 3 blok, dimana antar blok dipisahkan oleh jalan pemisah yang berupa jalan beraspal.

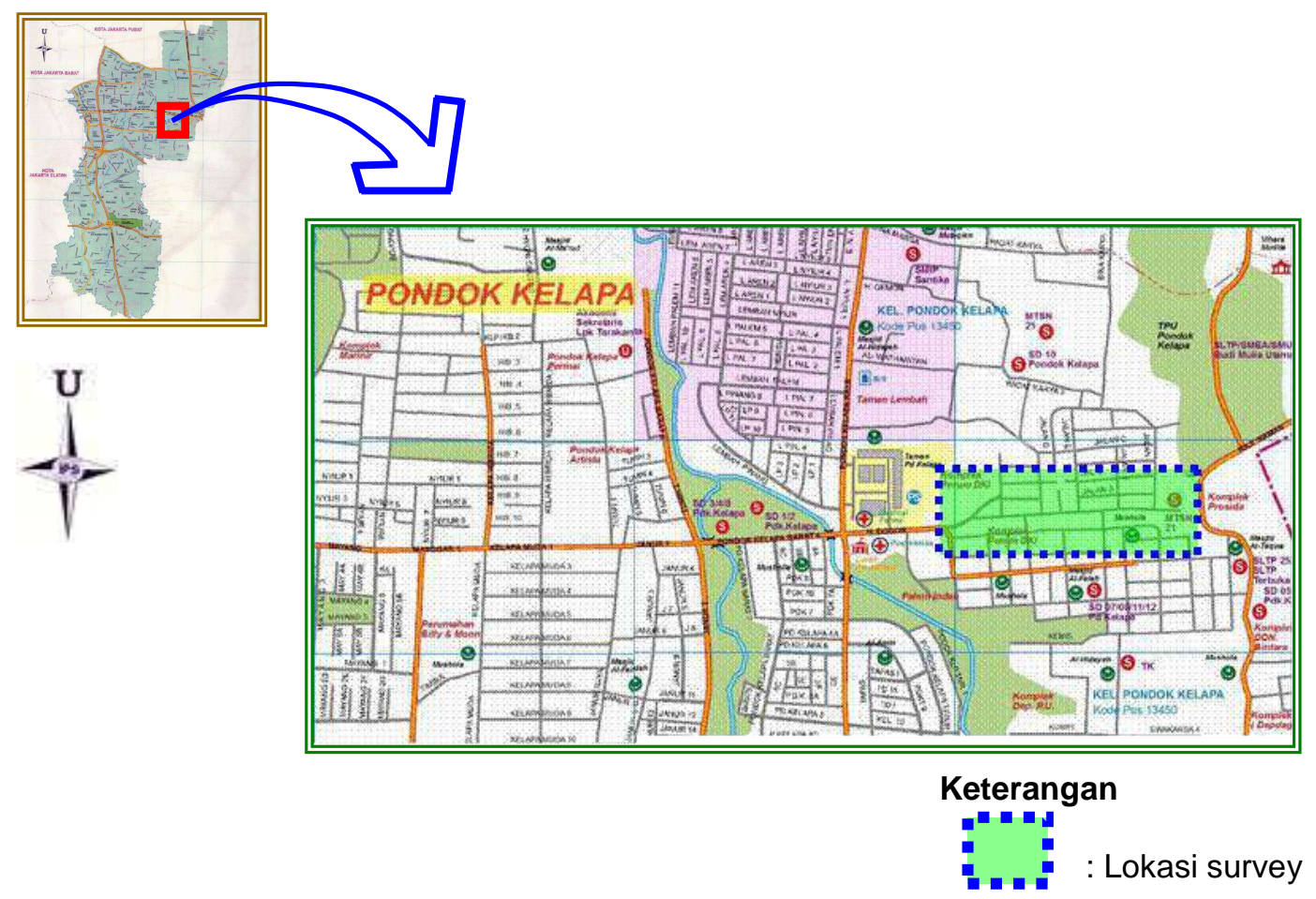

Gambar 17 Lokasi survey, Taman Hutan Kota, Kompleks Perum Karyawan Pemda DKI, Jalan H. Dogol, Pondok Kelapa Raya. 
Wilayah KotamadyaJakarta Timur

Survey yang dilakukan di lapang, pada RTH Taman ini teridentifikasi sebanyak 988 individu pohon, yang terdiri atas: 381 pohon pada blok I; 317 pohon pada blok II, dan; sebanyak 290 pohon pada blok III. Individu-individu tersebut terdiri atas jenis pohon dengan spesies antara lain:
1. Glodogan
7. Mangga
13. Nangka
2. Tanjung
8. Jambu Air
14. Alpukat
3. Mahoni
9. Kapuk Randu
15. Asam Kranji
4. Angsana
10. Belimbing
16. Cassia
5. Kelapa Gading
11. Sawo
17. Sukun
6. Beringin
12. Kihujan
18. Belimbing Wuluh

Pada masing-masing blok Taman, memiliki vegetasi pohon dominan yang berbeda-beda. Pada Blok I, didominasi oleh pohon dengan jenis Glodogan, Tanjung dan Angsana. Pada Blok II, pohon-pohon penyusun taman didominasi oleh Mahoni, Glodogan dan Tanjung. Sedangkan pada Blok III, didominasi oleh pohon dengan jenis Tanjung dan Glodogan.
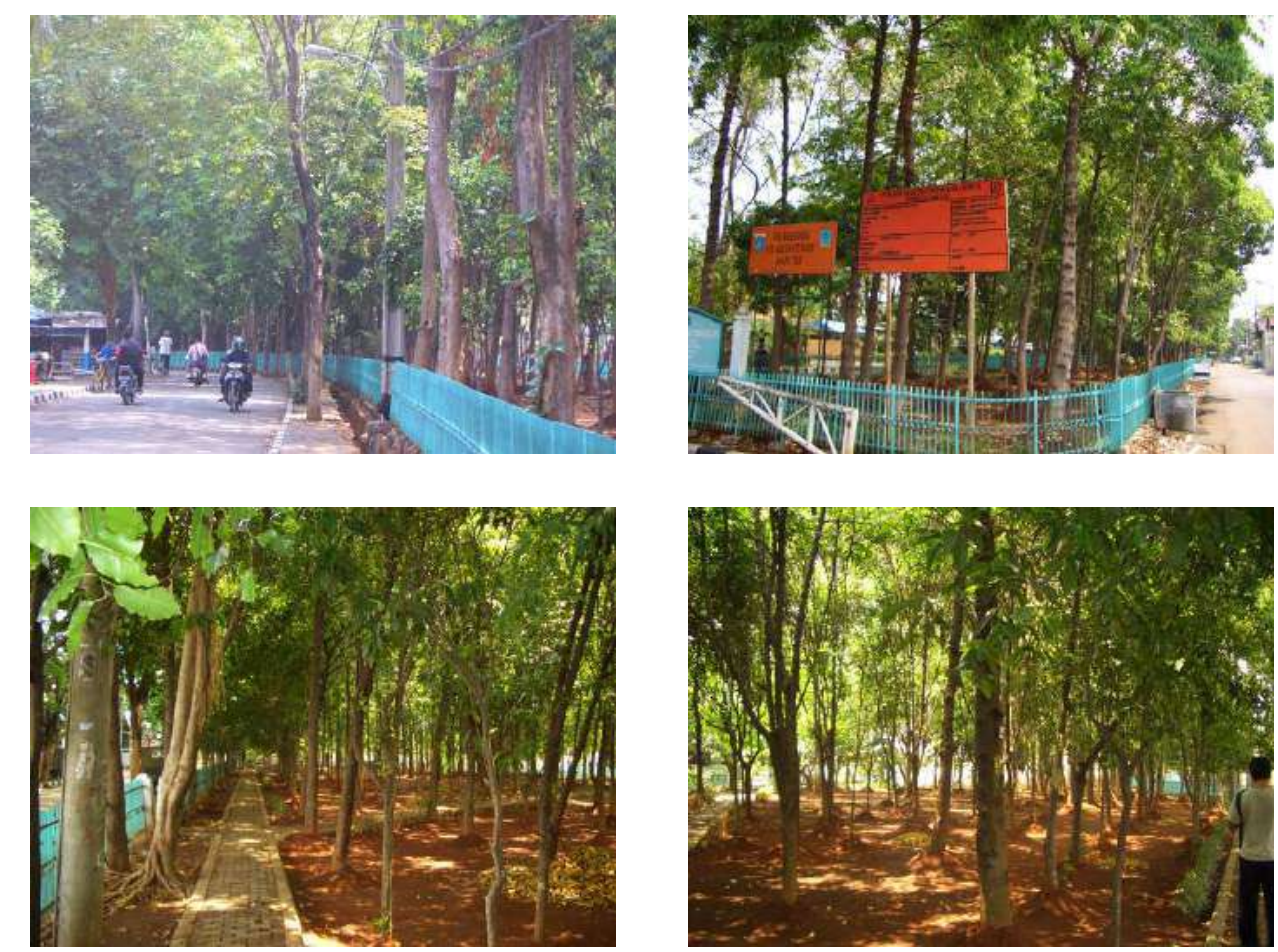

Gambar 18 Kondisi umum beberapa pohon di Taman Hutan Kota, Kompleks Perum Karyawan Pemda DKI, Jalan H. Dogol, Pondok Kelapa Raya.

Secara umum, kondisi pohon-pohon pada Taman Hutan Kota, Pondok Kelapa ini berada pada kondisi yang sehat, terutama untuk pohon-pohon muda. 
Wilayah KotamadyaJakarta Timur

Tetapi yang perlu diantisipasi adalah jarak tanam antar pohon yang cukup rapat, sehingga penetrasi sinar matahari menuju ke permukaan tanah itu kurang. Hal ini akan mengakibatkan tanaman yang menjulang tinggi karena saling berkompetisi untuk mendapat ketersediaan sinar matahari yang cukup. Di lain sisi, perakaran dan kondisi batang pohon muda (terutama untuk pohon jenis Glodogan, Tanjung dan Mahoni) belum cukup kuat untuk menopang ketinggian tanaman, sehingga seringkali mengakibatkan pohon tampak tidak proporsional (seperti melengkung, doyong, atau bahkan rubuh) dan mudah tumbang apabila bertiup angin yang cukup kencang. Oleh karena itu perlu dilakukan penanaman dengan jarak tanam yang proporsional, dengan mempertimbangkan aspek ketersediaan penetrasi sinar matahari. Agar tanaman dapat tumbuh dengan baik dan kuat terutama pada perakaran dan batangnya, sehingga tidak mudah roboh atau tumbang.

Hal lain yang cukup penting untuk diperhatikan adalah sampah yang sangat jelas tampak berserakan. Oleh karena itu, tindakan yang perlu dilakukan oleh Sudin Pertamanan Kotamadya Jakarta Timur sebagai pengelola RTH Taman tersebut untuk selalu melakukan himbauan dan pelarangan merusak pohon di dalam taman. Hal ini dimaksudkan untuk membatasi serta meminimalisasi kerusakan-kerusakan (terutama yang disebabkan oleh masyarakat) sekaligus sebagai tindakan preventif terhadap kerusakan-kerusakan mekanik terhadap pohon. 
Wilayah KotamadyaJakarta Timur

\subsection{HASIL PEMETAAN LETAK TITIK POHON PADA JALUR HIJAU JALAN DAN RTH PERTAMANAN WILAYAH JAKARTA TIMUR}

\subsubsection{Pemetaan Titik Pohon pada Jalur Hijau Jalan Raya Bogor}
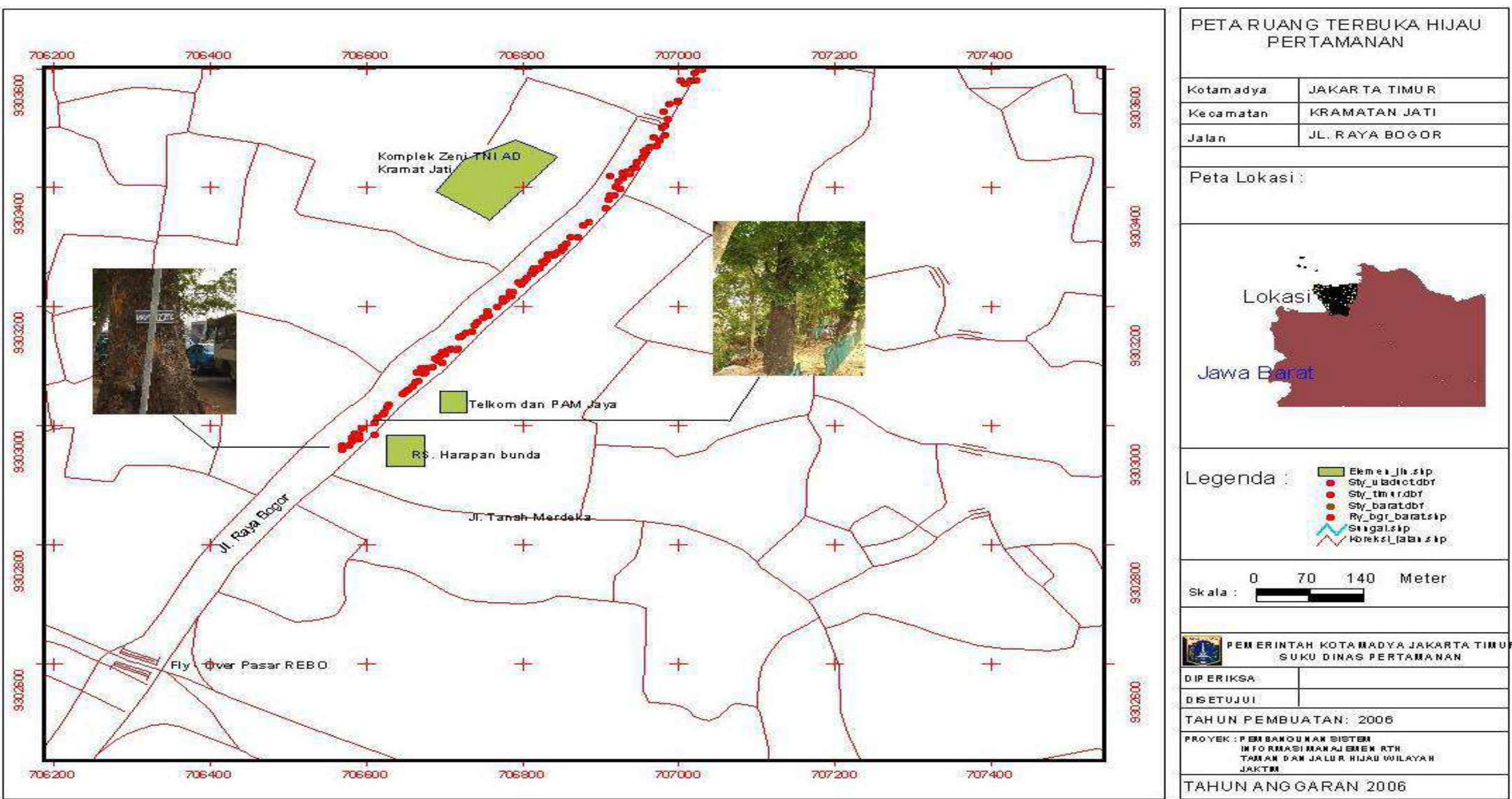
Pembangunan Sistem Informasi Manajemen RTH Taman dan Jalur Hijau

Wilayah KotamadyaJakarta Timur

\section{Pemetaan Titik Pohon pada Jalur Hijau Jalan Raya Bogor ( L a n j u t a n )}
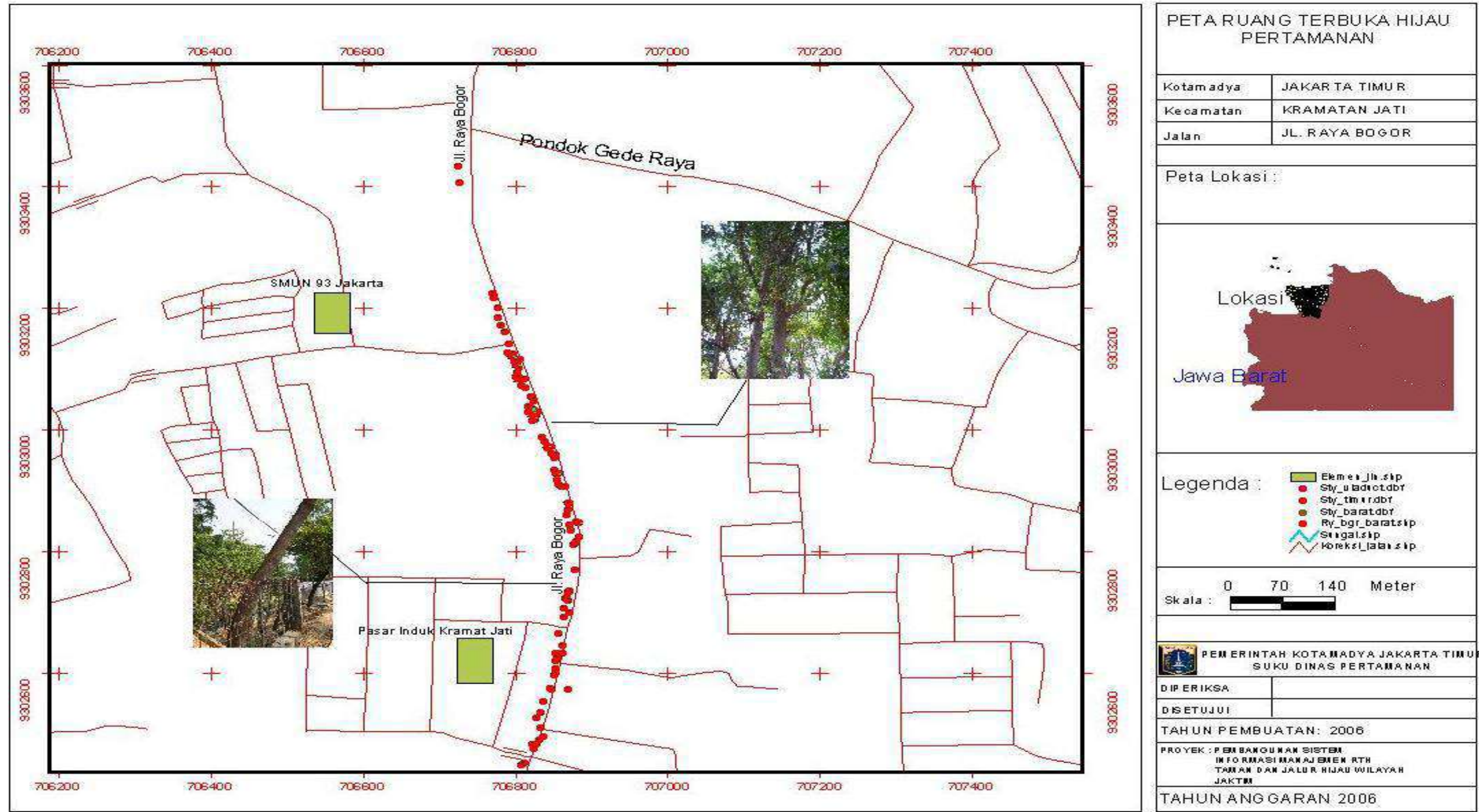
Pembangunan Sistem Informasi Manajemen RTH Taman dan Jalur Hijau

Wilayah KotamadyaJakarta Timur

\subsubsection{Pemetaan Titik Pohon pada Jalur Hijau Jalan Mayjen Sutoyo}
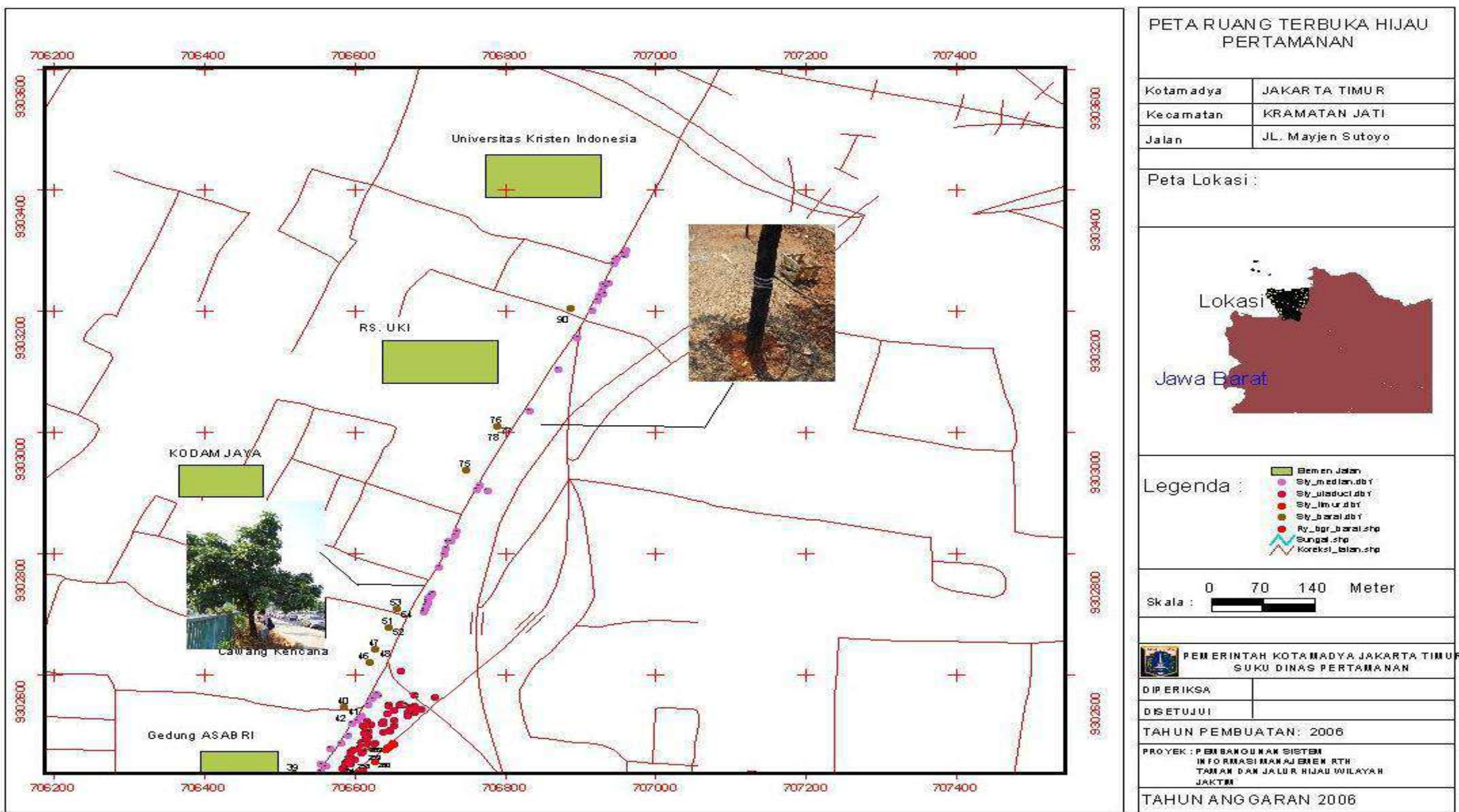
Pembangunan Sistem Informasi Manajemen RTH Taman dan Jalur Hijau Wilayah KotamadyaJakarta Timur

\subsubsection{Pemetaan Titik Pohon pada Jalur Hijau Jalan Jend. Ahmad Yani}

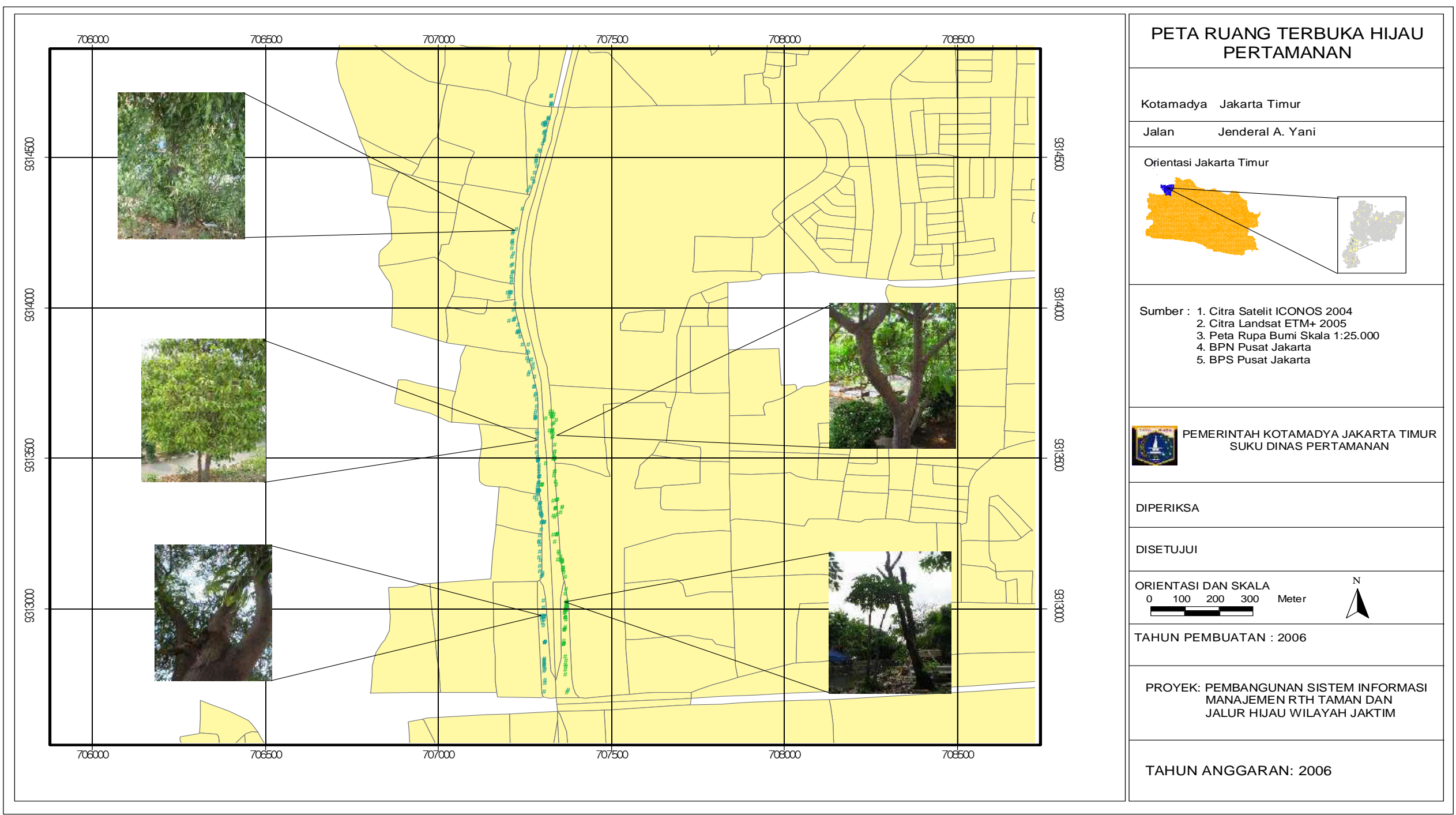




\section{BAB 4}

\section{PEMBAHASAN DAN PEMBANGUNAN SISTEM}

\subsection{SISTEM INFORMASI GEOGRAFIS}

Untuk dapat mengoperasikan Sistem Informasi Ruang Terbuka Hijau dalam ArcView V3.2 ini, pengguna harus melakukan langkah - langkah sebagai berikut:

1. Boot komputer sampai keluar windows.

2. Melalui start up menu pilih program $>$ ArcView V3.2

3. Klik menu file, terlebih dahulu buat default semua ekstensien.

4. Klik file > Open Project > Buka directories data ArcView dengan ekstensi ${ }^{*}$.Apr. $>$ OK.

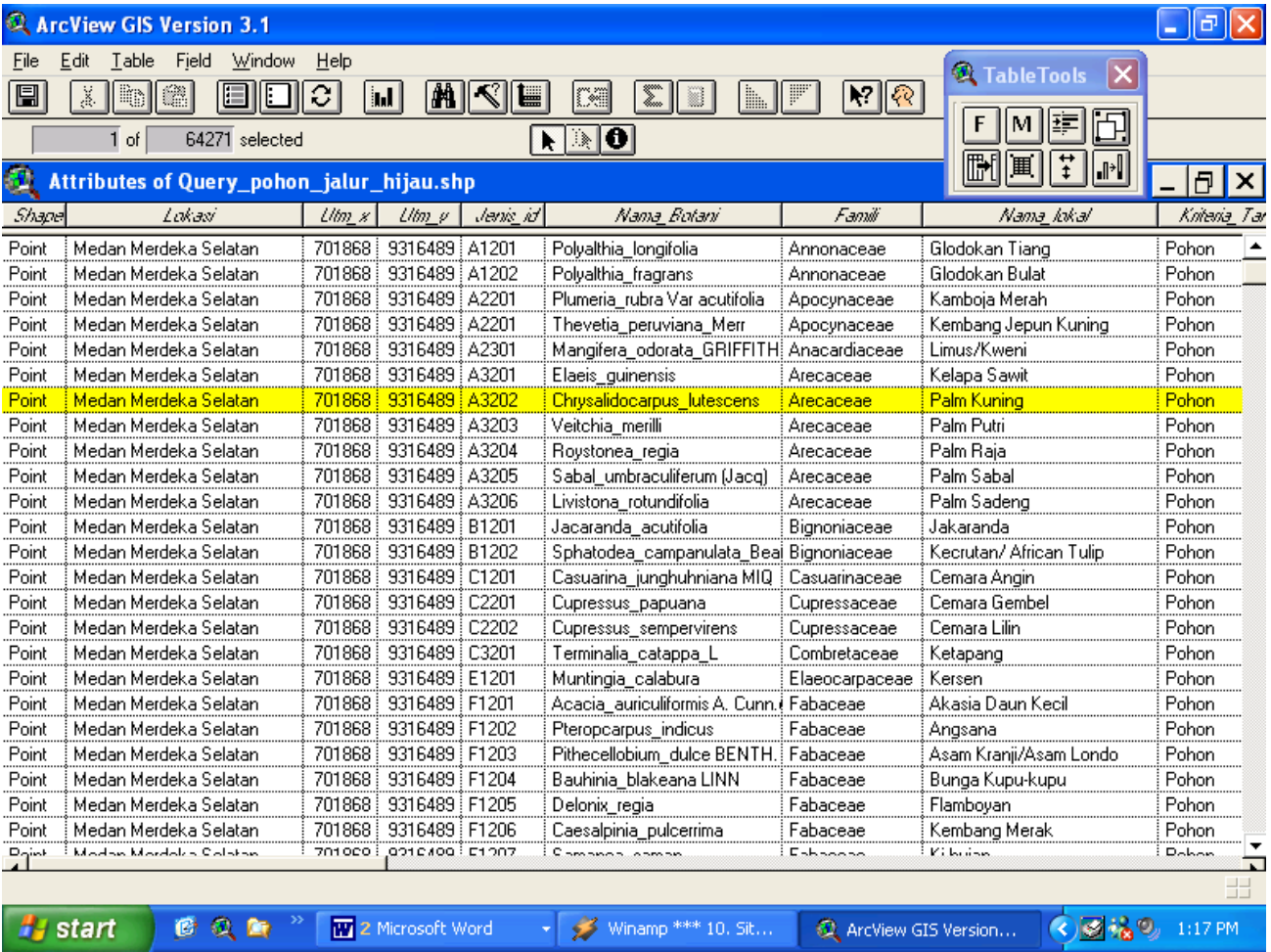

Gambar 19 Contoh menu bar tabel dalam ArcView memberikan kemudahan untuk updating file atau data.

ArcView memberikan kemudahan dalam mendapatkan informasi yang diinginkan karena file - file induk akan terkumpul dalam sebuah file yang berekstensi *.Apr dan tampilan view menu data atribut dengan data spasial bersebelahan sehingga navigasi dapat dengan mudah dilakukan dengan 
Wilayah KotamadyaJakarta Timur

menekan botton bar $\boldsymbol{i}$ (identify) pada menu bar utama, pan untuk menggeser posisi spasial, hot link untuk menampilkan visual, find untuk mencari file yang dikehendaki, zoom in untuk membesarkan area pengamatan dan zoom out untuk melakukan hal sebaliknya. Seperti yang telah dijelaskan di atas pengguna (user) dapat melakukan browsing dari menu view ke menu tabel dengan menekan botton bar Open Theme Table.

Dalam view tabel pun pengguna dapat melakukan proses editing dalam menu > Tabel > Start Editing (Gambar 18). Dalam SMBD Access 2002, file basis data sistem informasi pengelolaan ruang terbuka hijau disimpan dalam bentuk *.mdb dengan nama file Access_Data_View. Untuk memudahkan pengguna dalam mencari informasi yang diinginkan mengenai data atribut, dibuat menu navigasi mengenai basis data inventarisasi jalur hijau pertamanan dan jalan di Jakarta Timur.

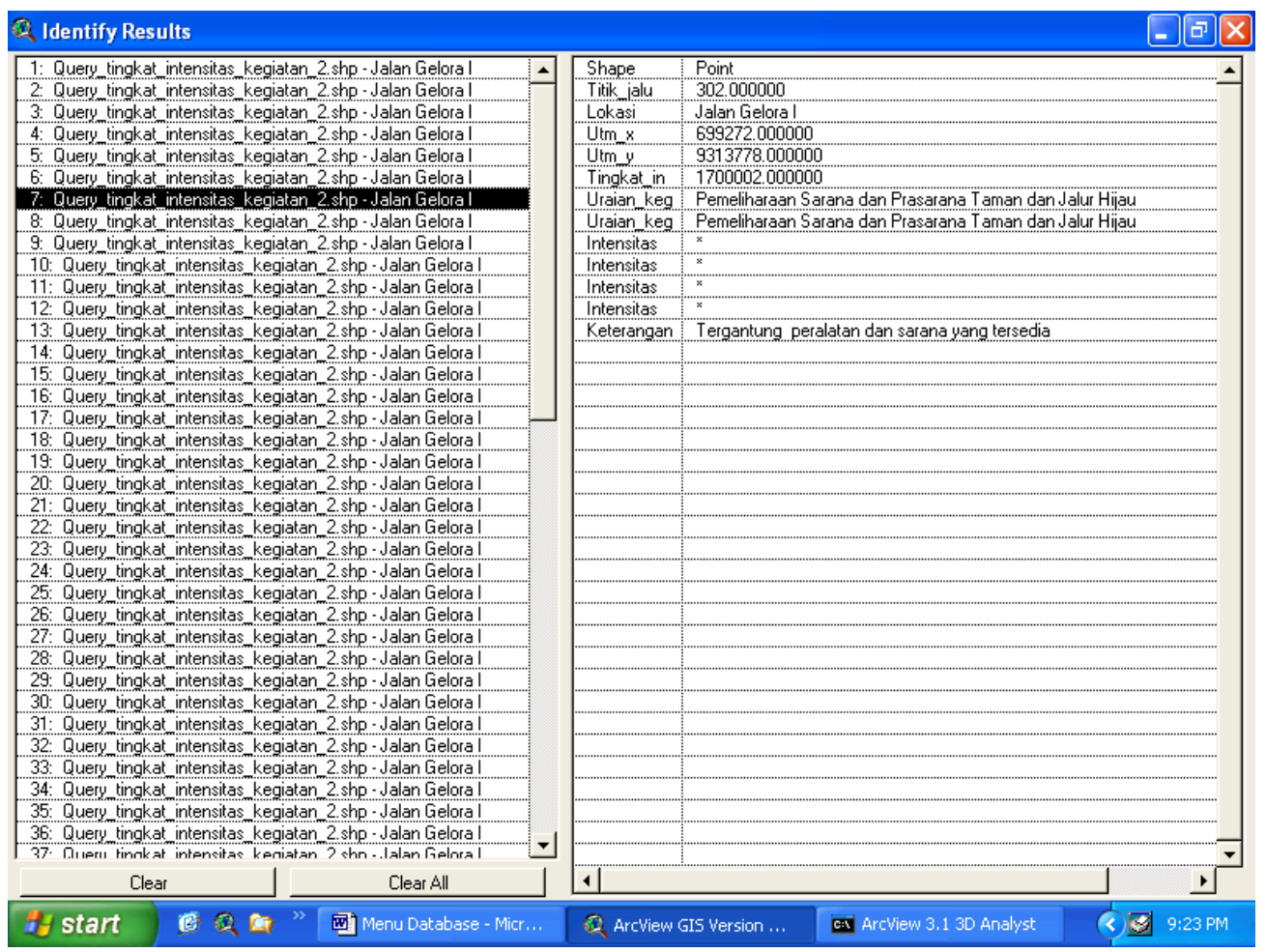

Gambar 20 Contoh tampilan browsing data dengan menggunakan tool bar identify.

\subsubsection{Analisis (Query) SIG}

Query ini berguna untuk penelusuran data dalam suatu basis data. Pada ArcView V3.2 query dapat dilakukan dengan fasilitas SQL Connect data query tabel. Hasil dari query dalam access 2002 dapat disimpan dalam satu set tabel, 
sebagai file query dan sebuah query memungkinkan untuk menentukan atau memilih field mana yang akan ditampilkan dalam database ArcView V3.2

Untuk menampilkan Query yang diinginkan, harus dibuat suatu pernyataan logika atas informasi yang diinginkan. Dalam perancangan query sistem informasi pengelolaan ruang terbuka hijau ini pernyataan logika ditulis dengan menggunakan bahasa makro sebagaimana terdapat dalam access 2002. Pernyataan logika dirancang sedemikian rupa untuk memenuhi kualifikasi data data yang akan dieksekusi ke dalam ArcView.

Query ditetapkan berdasarkan kriteria pohon. Semua query di atas digabungkan dengan koordinat referensi UTM. Agar pengguna bisa dengan mudah mendapatkan informasi yang diinginkan, dibuat linking data ke dalam ArcView V3.2 dengan menggunakan fasilitas SQL Connect dan Create query in Design View pada Access. Query yang dibuat menggabungkan 2 tabel, sedangkan untuk query tanaman, kebutuhan THL, inventarisasi jalur hijau, rencana anggaran pemeliharaan, dan tingkat intensitas kegiatan dirancang menurut indeks klasifikasi pengecekan GPS (Global Positioning System) di lapangan yang dalam hal ini dikelompokkan menjadi 6 kelompok jalur utama.

\subsubsection{Penyajian Hasil SIG}

Penyajian hasil dari basis data Sistem Informasi Manajemen RTH dan Jalur Hijau Wilayah Jakarta Timur ini dapat berbentuk dijital pada layar monitor dan dalam bentuk cetakan pada media kertas dengan model tampilan grafis, atribut, grafis-atribut. Model tampilan grafis-atribut dapat dilihat dengan menggunakan program ArcView 3.2. Untuk tampilan atribut saja dapat ditampilkan dengan menggunakan SMBD Access 2002.

Langkah-langkah untuk menampilkan data atribut dan data grafis dengan query tanaman Jalur hijau_koordinat UTM dengan Arc View V3.1 adalah sebagai berikut :

1. Klik menu project $>S Q L$ Connect

2. Pilih tabel query yang akan dimasukkan

3. Klik windows > Tile Windows

Apabila ingin menambah tampilan,

4. Klik new project pada menu file

5. Klik OK untuk lebih lanjut menyimpannya dalam folder terpisah

Berikut adalah gambar contoh tampilan query_Pohon. Microsoft Access hanya dapat menyajikan data atribut saja. Bagi memudahkan pengguna, dibuat 
Wilayah KotamadyaJakarta Timur

menu navigasi yang memudahkan pengguna mendapatkan informasi mengenai basis data Sistem Informasi Pengelolaan Ruang Terbuka Hijau dalam bentuk formulir atau report.

Untuk mendapatkan informasi yang diinginkan langkah-langkahnya adalah sebagai berikut:

1. Klik "Open Existing File"

2. Pilih file Data_Access_View.mdb

3. Pilih Fasilitas Form

4. Pilih menu yang diinginkan.

5. Pengguna (user) dapat dengan mudah membuka dan menutup basis data yang diinginkan.

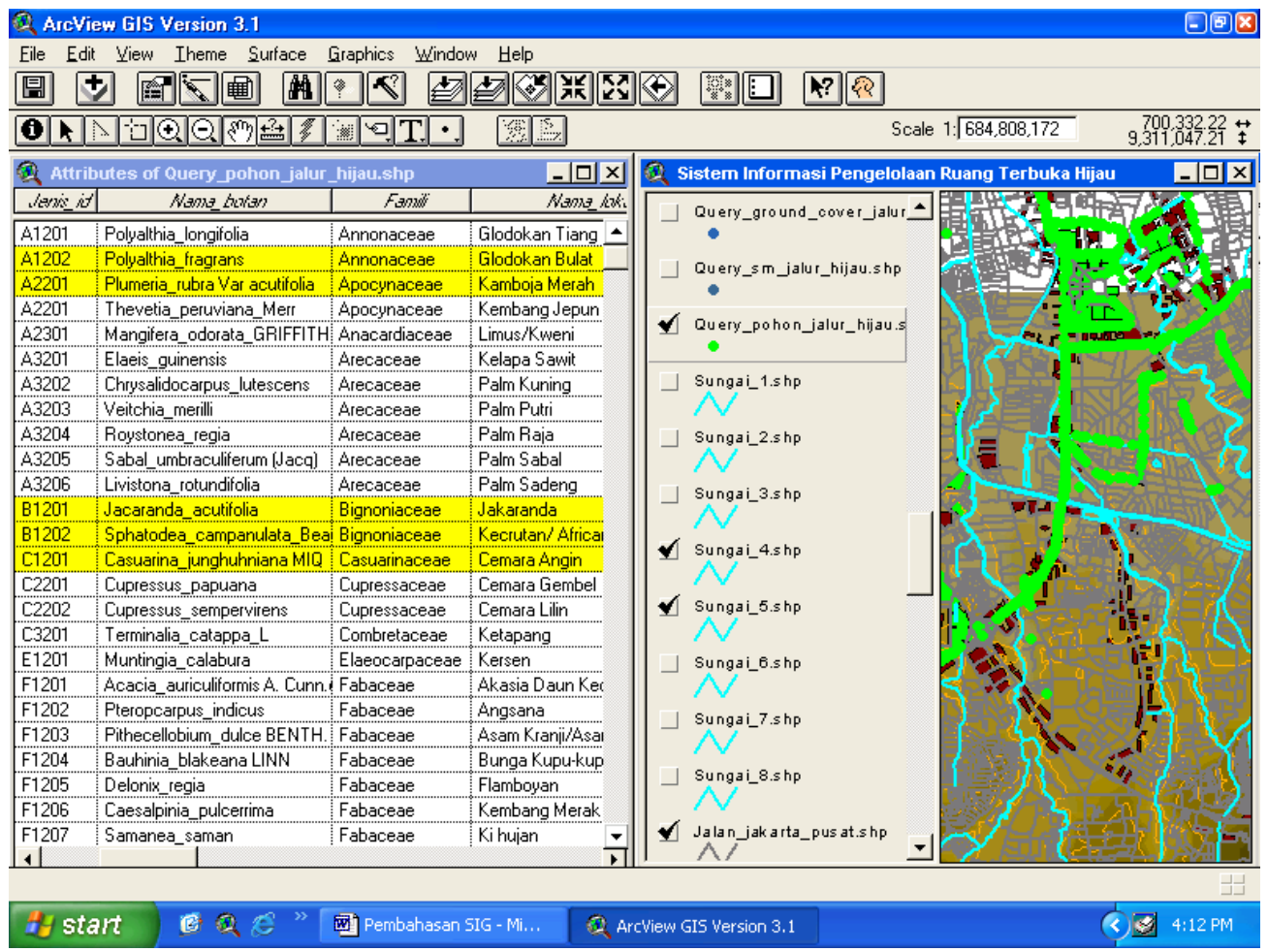

Gambar 21 Contoh tampilan pada layar monitor dengan model grafis-atribut untuk query UTM_Pohon.

\subsection{SISTEM INFORMASI BERBASIS OBJEK}

\subsubsection{Database dan Sistem Manajemen Database}

Data merupakan fakta yang masih mentah dan berdiri sendiri-sendiri.

Secara sederhana data dapat didefinisikan sebagai angka-angka, kata, nama dan lambang-lambang lainnya yang memiliki nilai. Dengan demikian data 
merupakan fakta yang belum mengalami pemrosesan lebih lanjut dan belum terorganisasi dengan baik. Data merupakan raw material untuk suatu informasi.

Database adalah sebuah obyek yang kompleks untuk menyimpan informasi yang terstruktur, yang diorganisir dan disimpan dalam suatu cara yang menizinkan pemakainya dapat mengambil informasi dengan cepat dan efisien. Database dipandang sebagai kumpulan data yang masing-masing saling berkaitan. Database merupakan kumpulan dari satu atau lebih tabel yang di dalamnya memiliki sekumpulan record-record. Database atau biasa disebut basis data adalah kumpulan data yang berhubungan dengan suatu obyek, topik atau tujuan khusus tertentu, sebagai contoh buku telepon, kamus bahasa, katalog buku di perpustakaan, data koleksi musik dan video, data pelanggan, data supplier, data mahasiswa, data pegawai dan lain-lain.

Database dirancang sedemikian rupa agar bisa mengambil data dengan mudah. Informasi dipecah-pecah ke dalam tabel-tabel, dan setiap tabel menyimpan entiti-entiti yang berbeda (satu tabel menyimpan informasi pohon, tabel yang lain menyimpan informasi penilaian pohon dan sebagainya). Informasi dipecah-pecah kedalam bagian-bagian kecil, agar bisa mengelolanya dengan mudah (memecah-belah). Dalam hal ini bisa dirancang aturan untuk melindungi database dari tindakan user serta meminta DBMS untuk menerapkan aturan-aturan ini (sebagai contoh, menolak user yang akan mengedit data). Aturan-aturan ini diberlakukan bagi semua item yang disimpan dalam tabel informasi.

Informasi secara fisik disimpan dan diambil dari database oleh sebuah program yang disebut dengan database management system (DBMS). DBMS adalah aplikasi yang paling kompleks, dan DBMS yang moderen secara langsung mencari sebuah record di dalam tabel yang memiliki jutaan record. Sistem manajemen basis data merupakan kumpulan file yang saling berkaitan bersama dengan program untuk pengelolaannya. Basis data adalah kumpulan datanya, sedang program pengelolanya berdiri sendiri dalam satu paket program yang komersial untuk membaca, mengisi, menghapus dan melaporkan data dalam basis data. Sementara DBMS mengelola semua informasi di dalam database, aplikasi lain bisa mengakses informasi ini melalui pernyataan yang dibuat dengan Stuructured Query Language (SQL), sebuah bahasa yang menentukan operasi high level. Opersi ini disebut dengan Query, dan ada dua jenis query: selection query, yang mengambil informasi dari database, dan action 
query yang mengupdate database. Bagaimana DBMS mengelola, mengupdate dan mengambil informasi ini adalah hal-hal yang tidak perlu ditangani oleh aplikasi.

Secara khusus, DBMS menyediakan fungsi-fungsi berikut ini :

1. DBMS mengizinkan aplikasi mendefinisikan struktur dari database dengan peryataan SQL. Sub bagian dari pernyataan SQL yang mendefinisikan atau mengedit struktur ini disebut dengan data definition language (DDL). Semua DBMS menggunakan antarmuka visual untuk mendefinisikan struktur dari database dengan opeasi klik dan tunjuk saja, tapi peranti ini menterjemahkan tindakan user ke dalam pernyataan DDL yang sesuai.

2. DBMS mengizinkan aplikasi memanipulasi informasi yang disimpan di dalam database dengan pernyataan SQL. Sub bagian dari pernyataan SQL yang memanipulasi informasi ini disebut dengan data manipulation language (DML). Teknik data-manipulation yang dasar misalnya seperti penyisipan record baru, modifikasi dan penghapusan record yang sudah ada serta pengambilan record.

3. DBMS melindungi integritas database dengan menerapakan beberapa aturan yang dimasukkan dalam perancangan database tersebut. Misalnya bisa menentukan nilai default, tidak mengizinkan field tertentu kosong, melarang pengahpusan record yang terhubung dengan record lain, dan sebagainya.

\subsubsection{Peranti Visual Database}

Peranti visual database dari visual basic menyederhanakan operasioperasi seperti perancangan dan pengambilan data dari database. Peranti ini bukanlah peranti pemograman, tetapi merupakan peranti untuk membantu mempersiapkan menulis kode untuk aplikasi. Semakin banyak menggunakan piranti ini semakin sedikit kode VB yang harus diketikkan. Cara ini hampir sama dengan membuat aplikasi biasa dengan VB.

\subsubsection{Perangkat Lunak SMBD Access 2000 For Windows}

Microsoft Access 2000 merupakan salah satu program aplikasi database paling lengkap dan canggih saat ini (Permana, 1999). Setiap program SMBD (Sistem Manajemen Basis Data) dilengkapi dengan fasilitas query yaitu pernyataan yang diajukan untuk mengambil informasi. 
Wilayah KotamadyaJakarta Timur

Pada Access, query tersebut dapat dilakukan pada data tabel dalam suatu set tabel atau dalam query lainnya. Hasil query dapat disimpan sebagai sebuah file query dan sebuah query memungkinkan untuk dapat menentukan atau memilih field mana yang akan di tampilkan dari suatu tabel.

\section{Struktur Data Dan Fasilitas pada SMBD Access 2000 For Windows}

Struktur basis data pada perangkat lunak SMBD Access for Windows yaitu relasional, dimana dalam pembentukan basis data relasional dapat di gabungkan antara data grafis dan data atribut. Fasilitas pada perangkat lunak SMBD Access for Windows yaitu:

\section{- Table}

Merupakan tempat yang digunakan basis data relasional untuk menangani data, dimana setiap tabel tersebut menyimpan data dalam record yang terdiri dari beberapa field (baris dengan beberapa kolom).

\section{- Query}

Merupakan pertanyaan untuk menyaring data dengan berbagai kriteria dan urutan yang diinginkan.

- Form

Dapat digunakan untuk memasukkan, menyunting dan mengamati data tabel dan query.

\section{- Report}

Meringkas informasi dalam tabel atau query.

- Macro

Merupakan daftar perintah sederhana. Dengan macro ini dapat menyimpan dan mengulang daftar perintah atau memainkan kembali perintah-perintah yang telah disimpan. Dengan kemampuan memainkan ulang ini, dapat mengotomatiskan operasi setiap kali bekerja dengan cara yang sama.

\section{- Module}

Merupakan program Access Basic. Dengan mengerti bahasa program Access Basic maka SMBD Access 2000 for Windows dapat dimanfaatkan dengan maksimal.

\subsubsection{Konfigurasi Perangkat Keras Untuk SMBD Access 2000 for Windows}

Menurut Permana (1999), untuk dapat menjalankan perangkat lunak SMBD Access for Windows 2000 pada PC IBM dibutuhkan konfigurasi komputer 
Wilayah KotamadyaJakarta Timur

minimal sebagai berikut: Prosessor Pentium 90, RAM 32 MB, harddisk 189 MB, monitor VGA, sebuah floppy disk drive dengan ukuran 3.5" high density dan CDROM Drive dan mouse.

\subsubsection{Aplikasi Manajemen Basis Data Dengan Microsoft Visual Basic 6.0}

MS-Visual Basic 6.0 adalah bahasa pemrograman yang bekerja dalam lingkup Microsoft Windows. MS-Visual Basic 6.0 dapat memanfaatkan kemampuan Microsoft Windows secara optimal. Kemampuannya dapat dipakai untuk merancang program aplikasi yang berpenampilan seperti program aplikasi lainnya berbasis MS-Windows (Alam, 1999).

\subsection{TAMPILAN PROGRAM DAN SISTEM YANG DIBANGUN}

\section{- Lay-out awal}

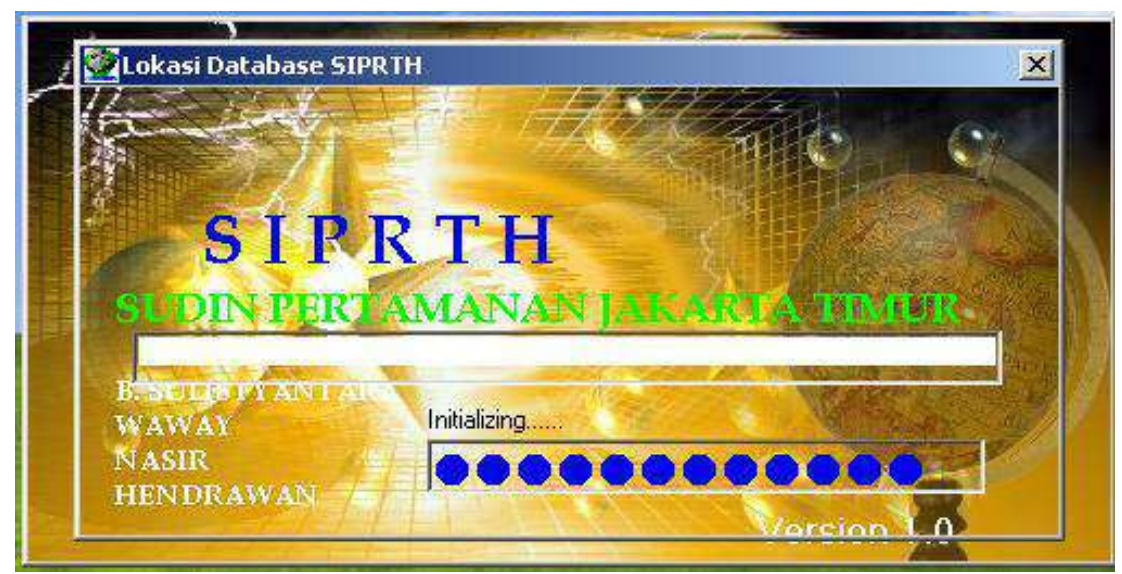

- Log-in menuju sistem dan memasukkan passwod
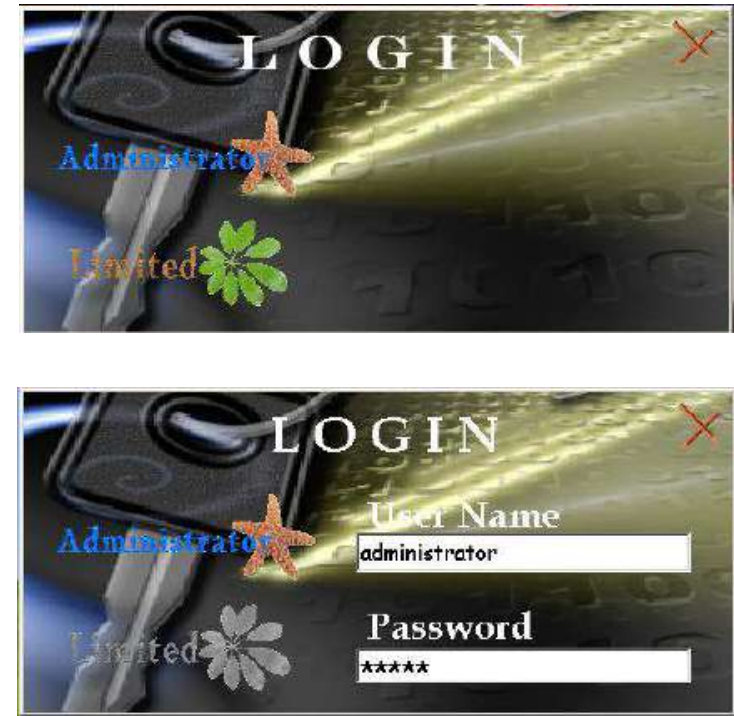
- Tampilan menu-menu utama (Pengelola; Kondisi Umum RTH; Inventori Pohon; Teknik Pemeliharaan Pohon)

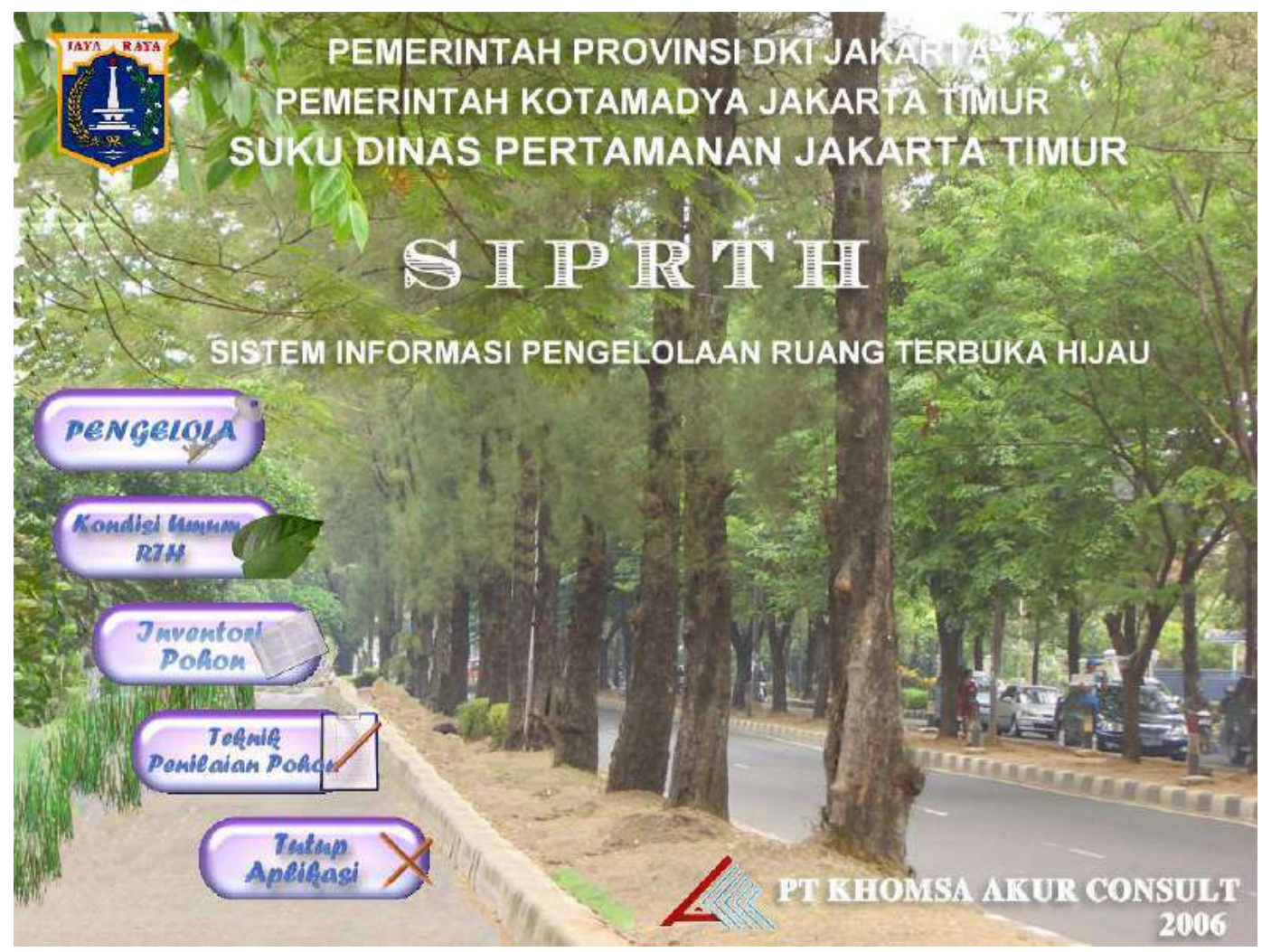

\section{- Tampilan pada sub menu-sub menu}

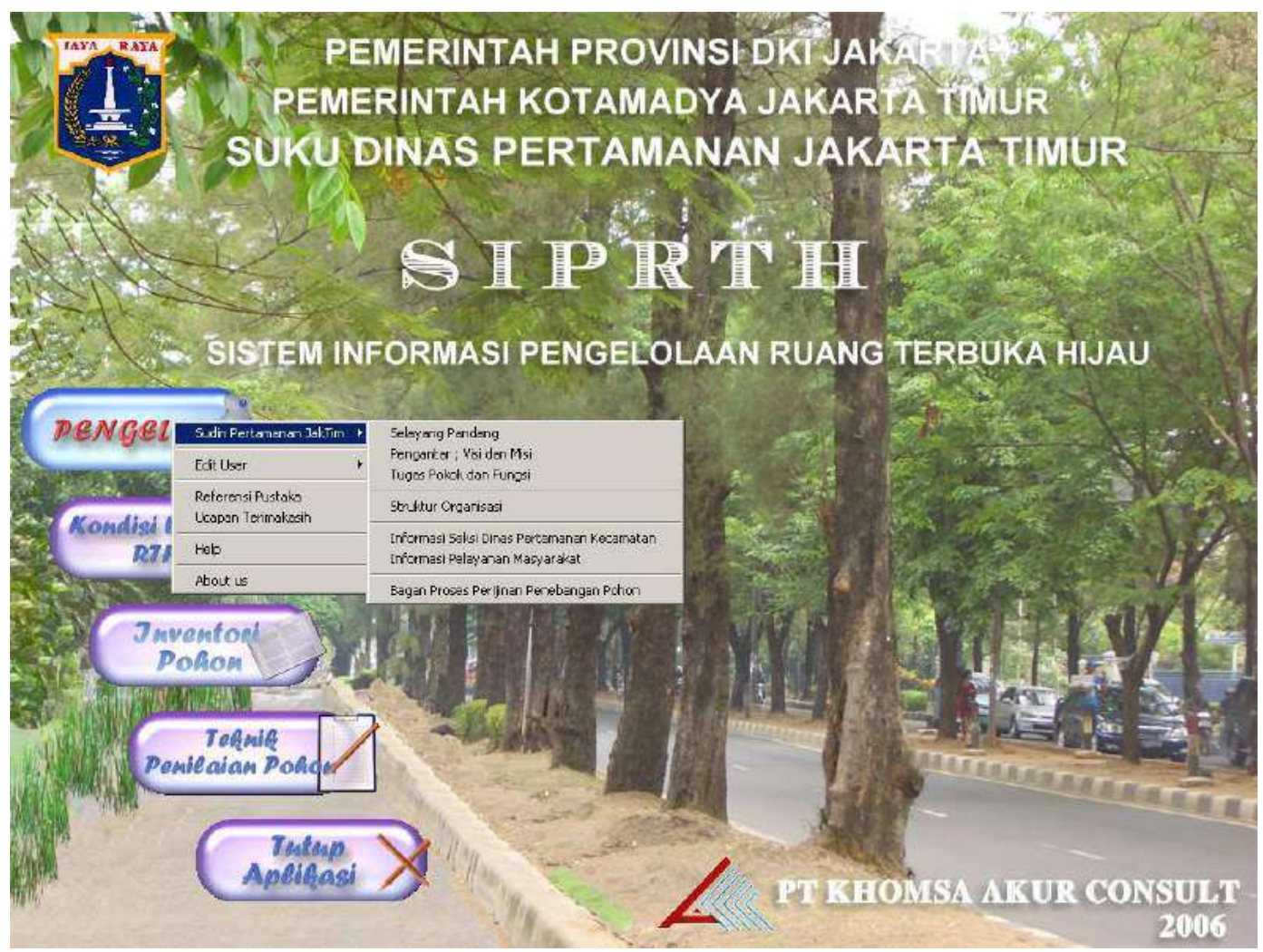


Wilayah KotamadyaJakarta Timur

\section{- Tampilan dalam menu Pengelola, sub menu Sudin Pertamanan Jaktim}

- Selayang Pandang

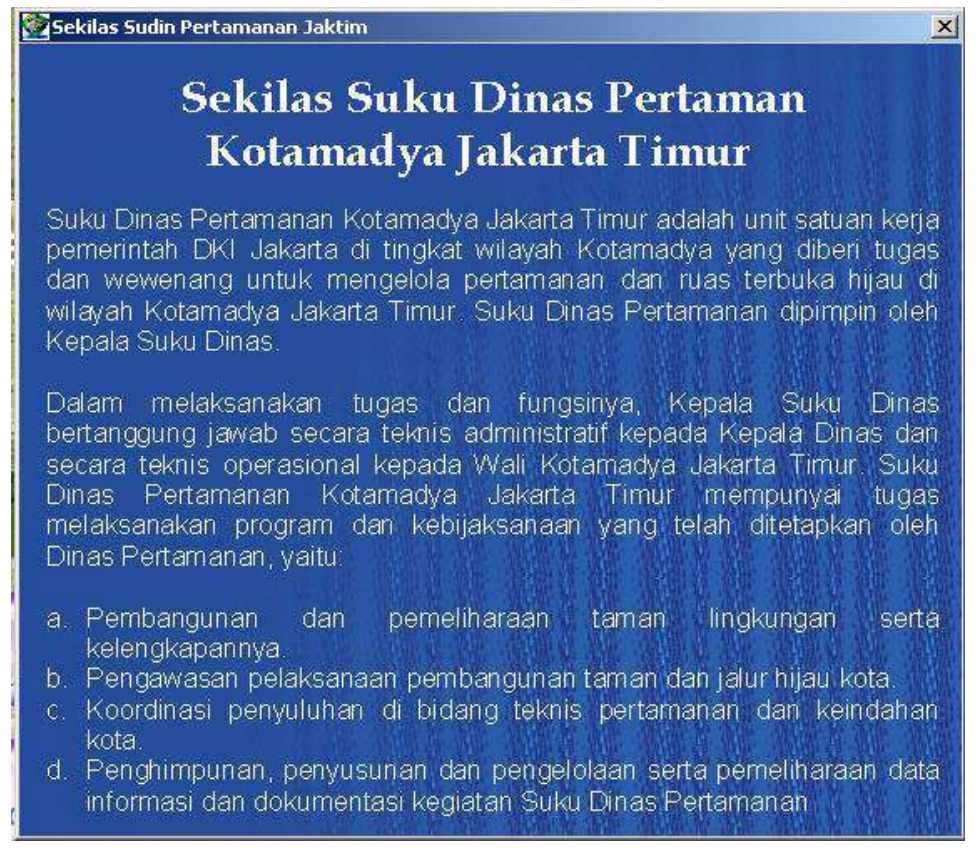

- Pengantar; Visi dan Misi

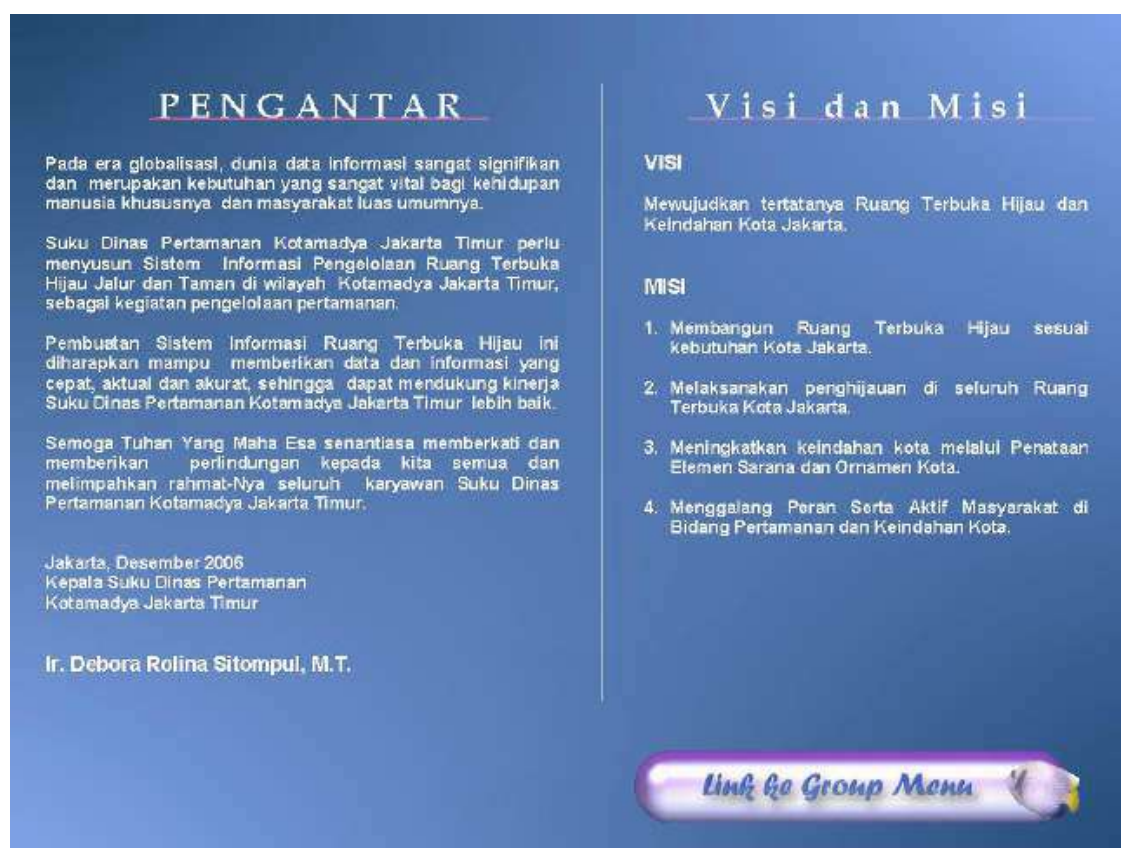


Wilayah KotamadyaJakarta Timur

- Tugas Pokok dan Fungsi

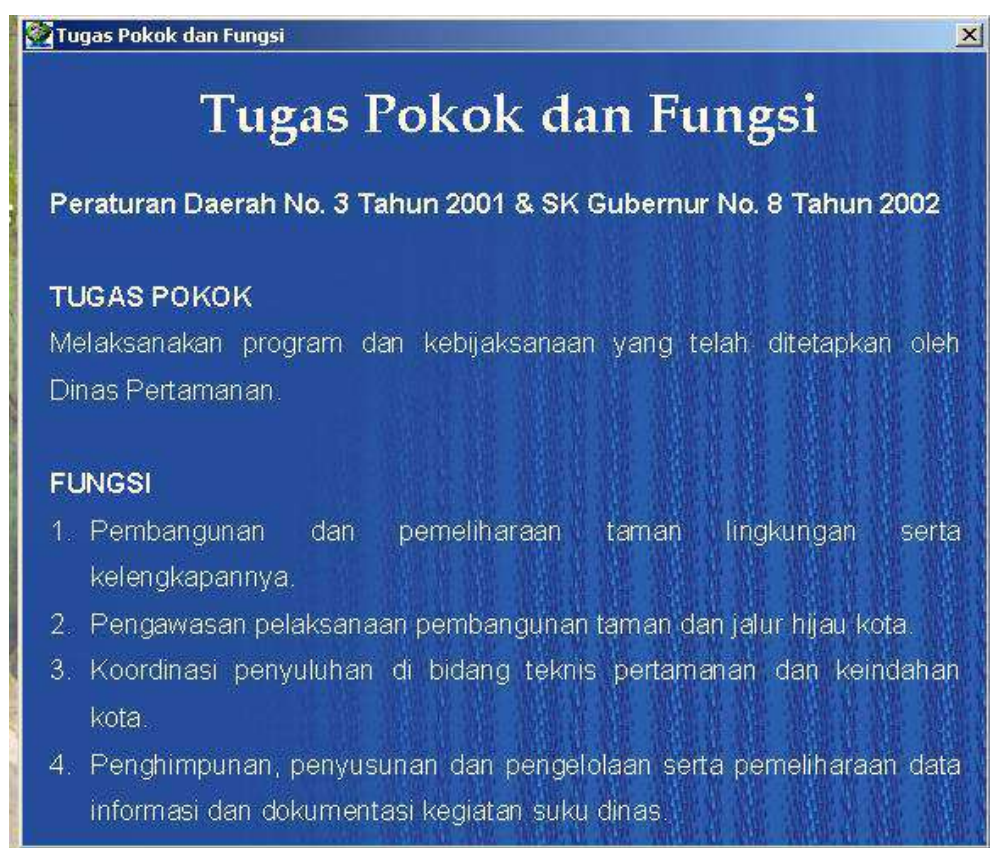

\section{- Tampilan dalam menu Kondisi Umum RTH}

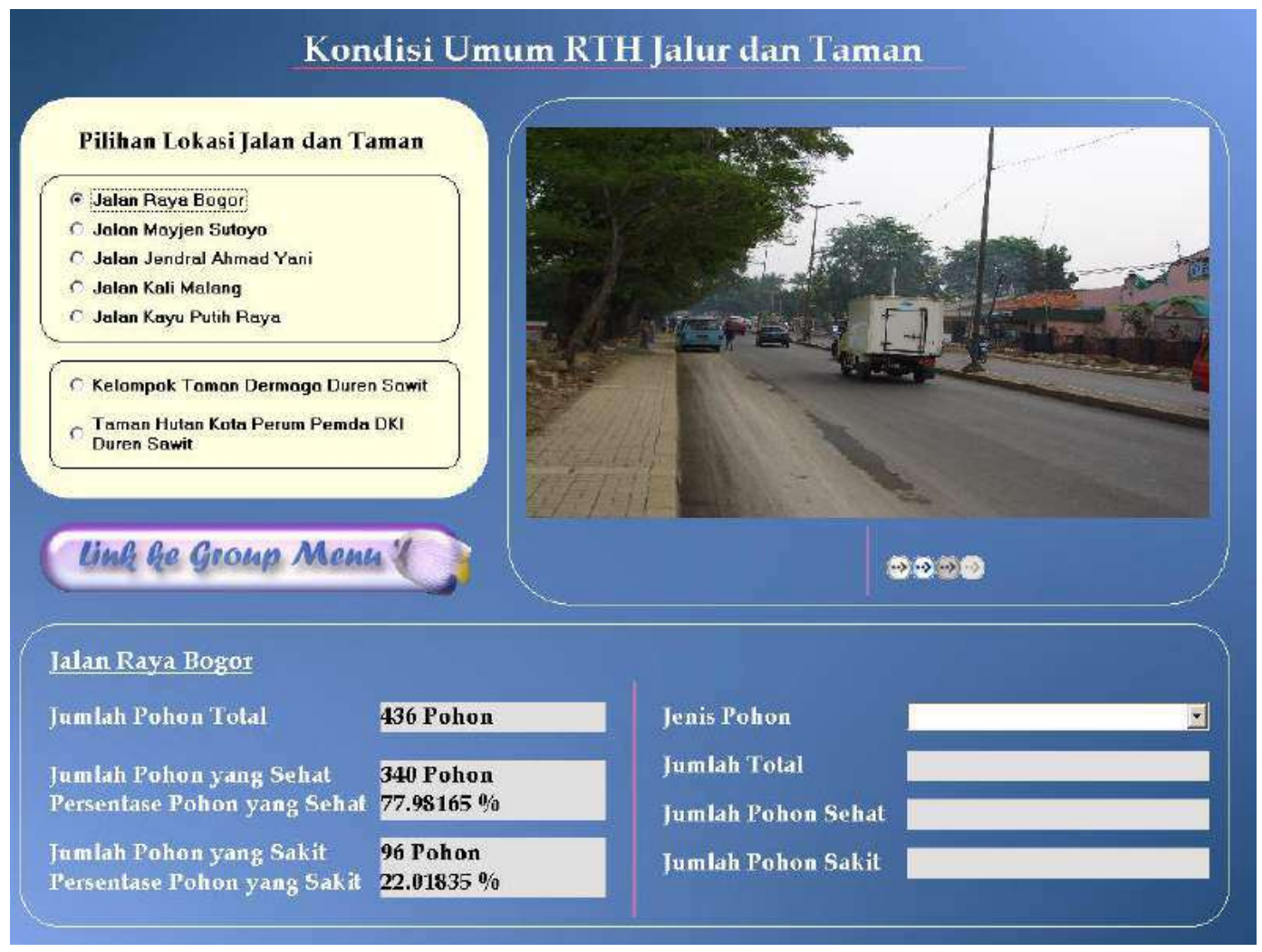


Wilayah KotamadyaJakarta Timur

\section{- Tampilan dalam menu Inventori Pohon}

\section{- Inventori Pohon}

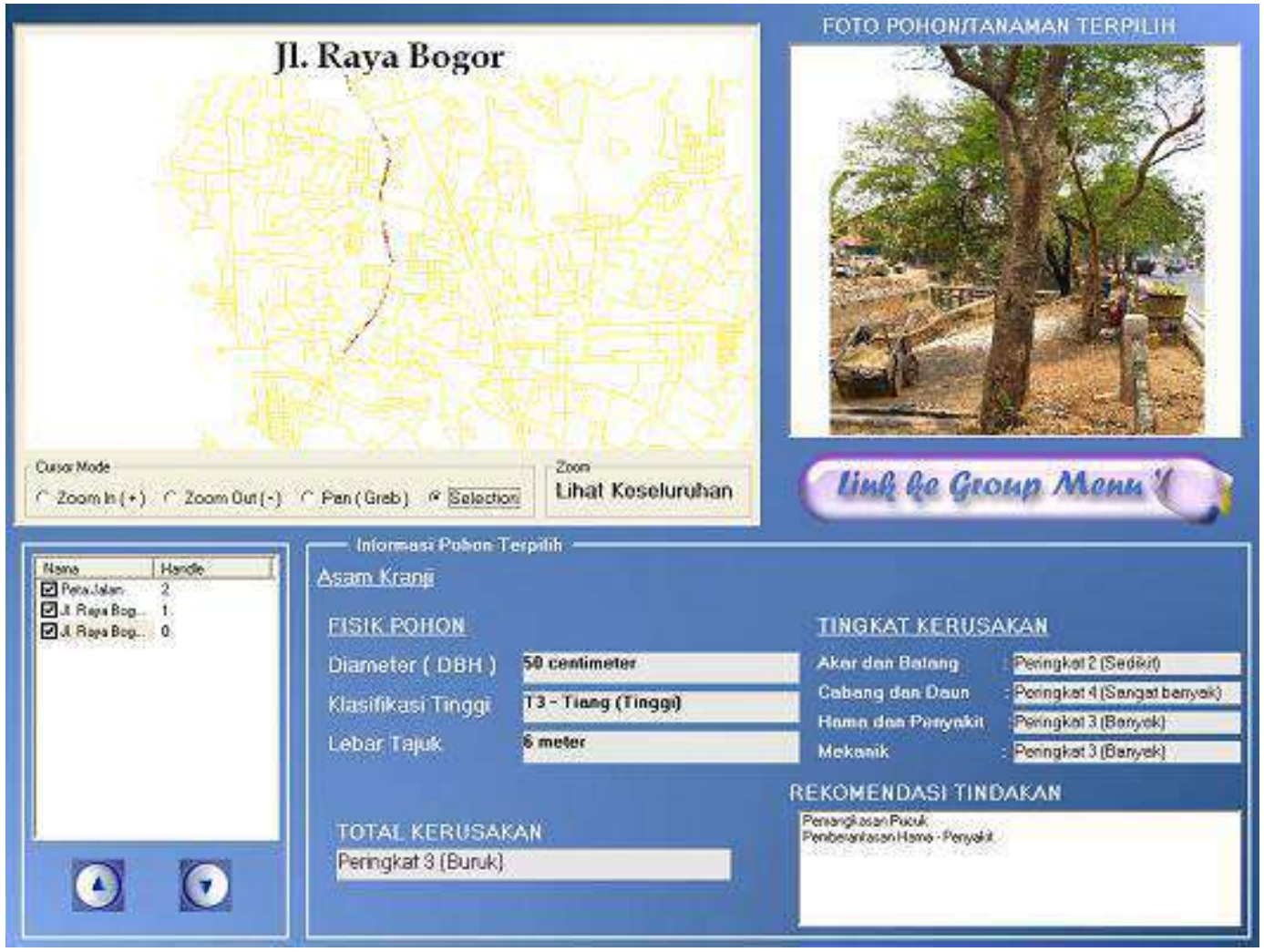

- Data Jumlah Pohon Berdasarkan Lokasi, Kondisi dan Jenis Pohon

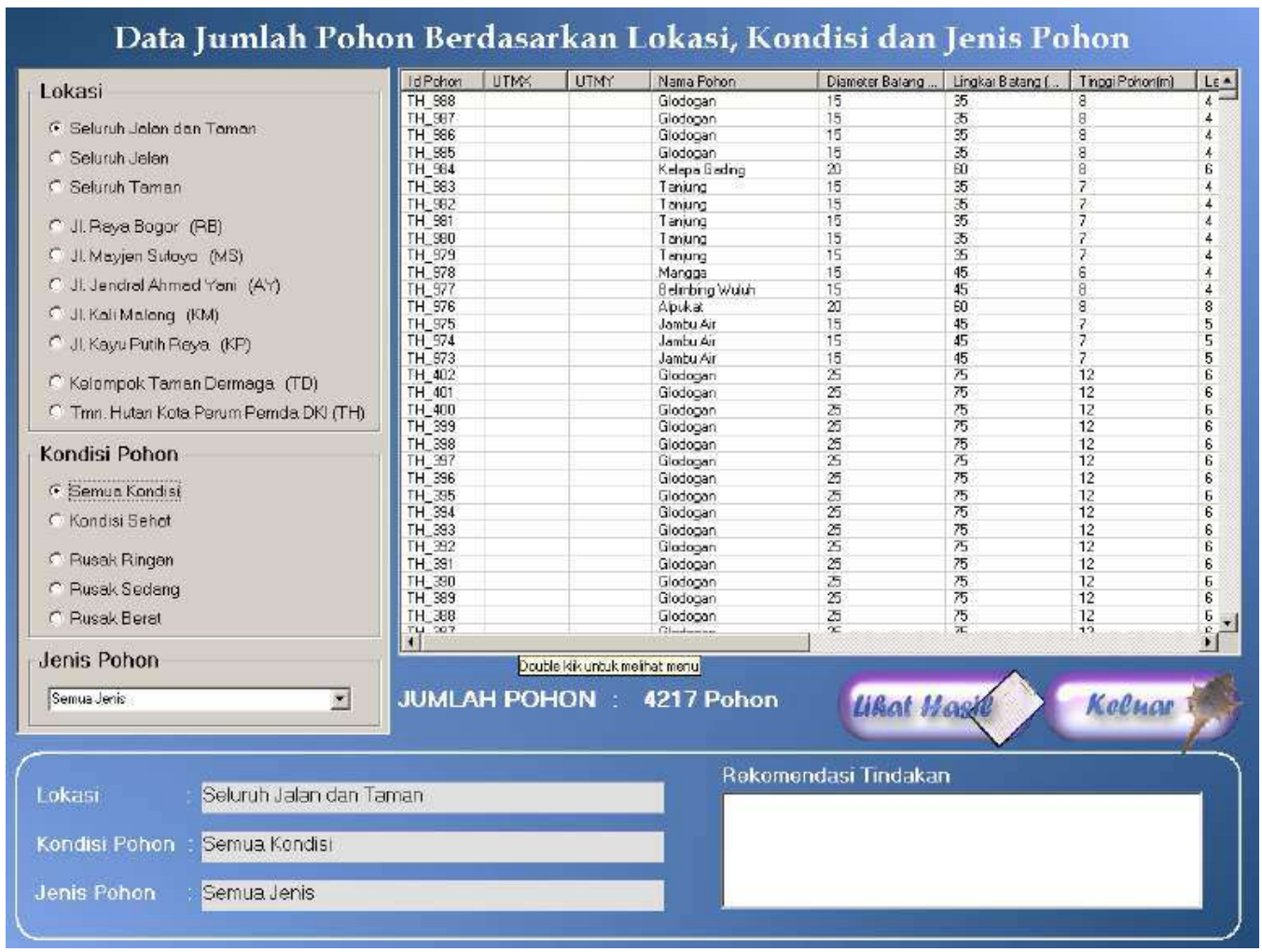




\section{- Referensi Tanaman Lanskap}

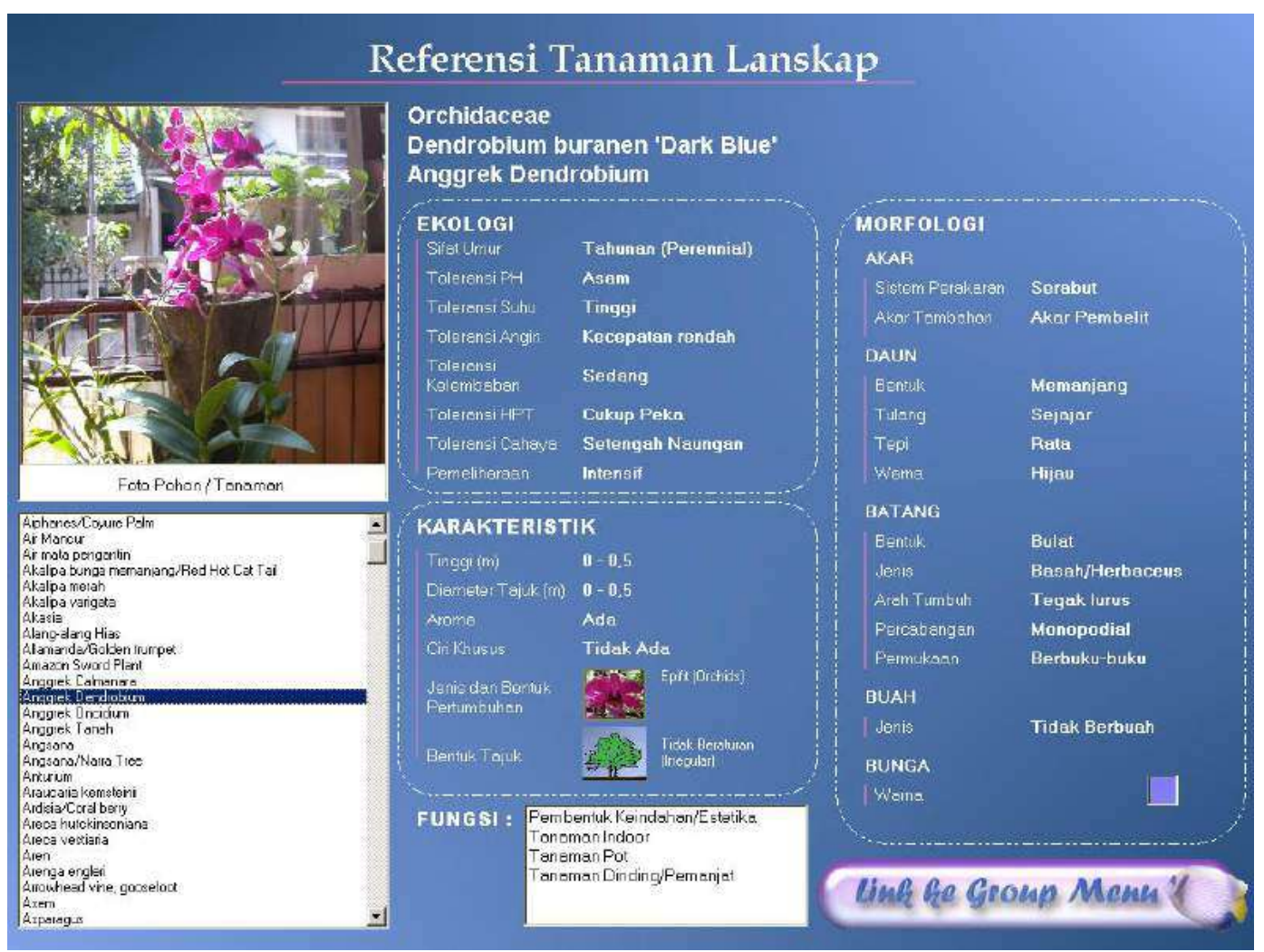

\section{- Referensi Proses Semenisasi pada Batang Pohon yang Gerowong}

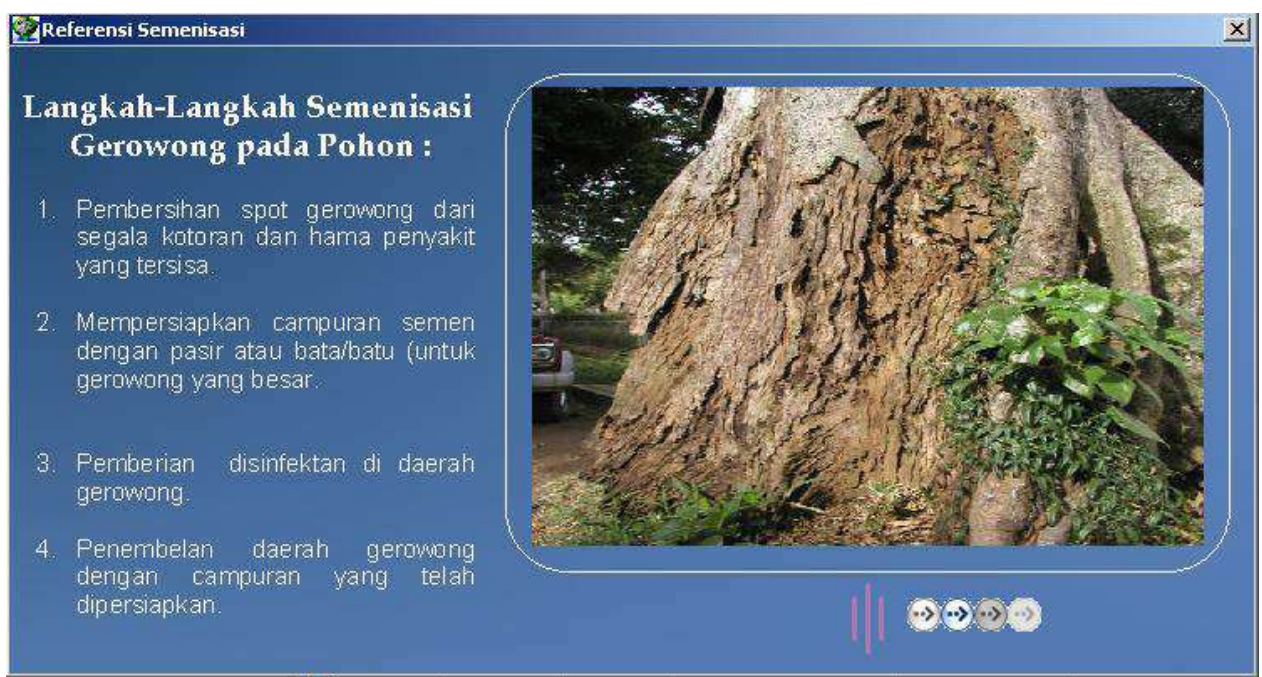




\section{- Referensi RTH di Malaysia - Singapura}
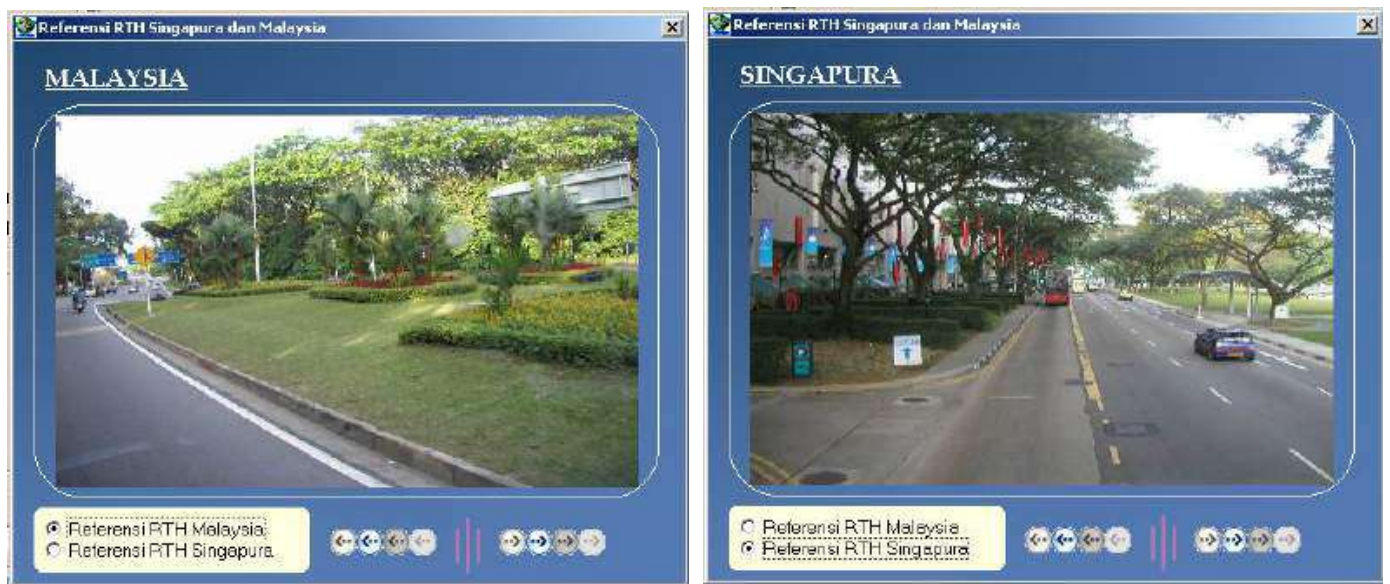

\section{- Tampilan dalam menu simulasi Teknik Penilaian Pohon}

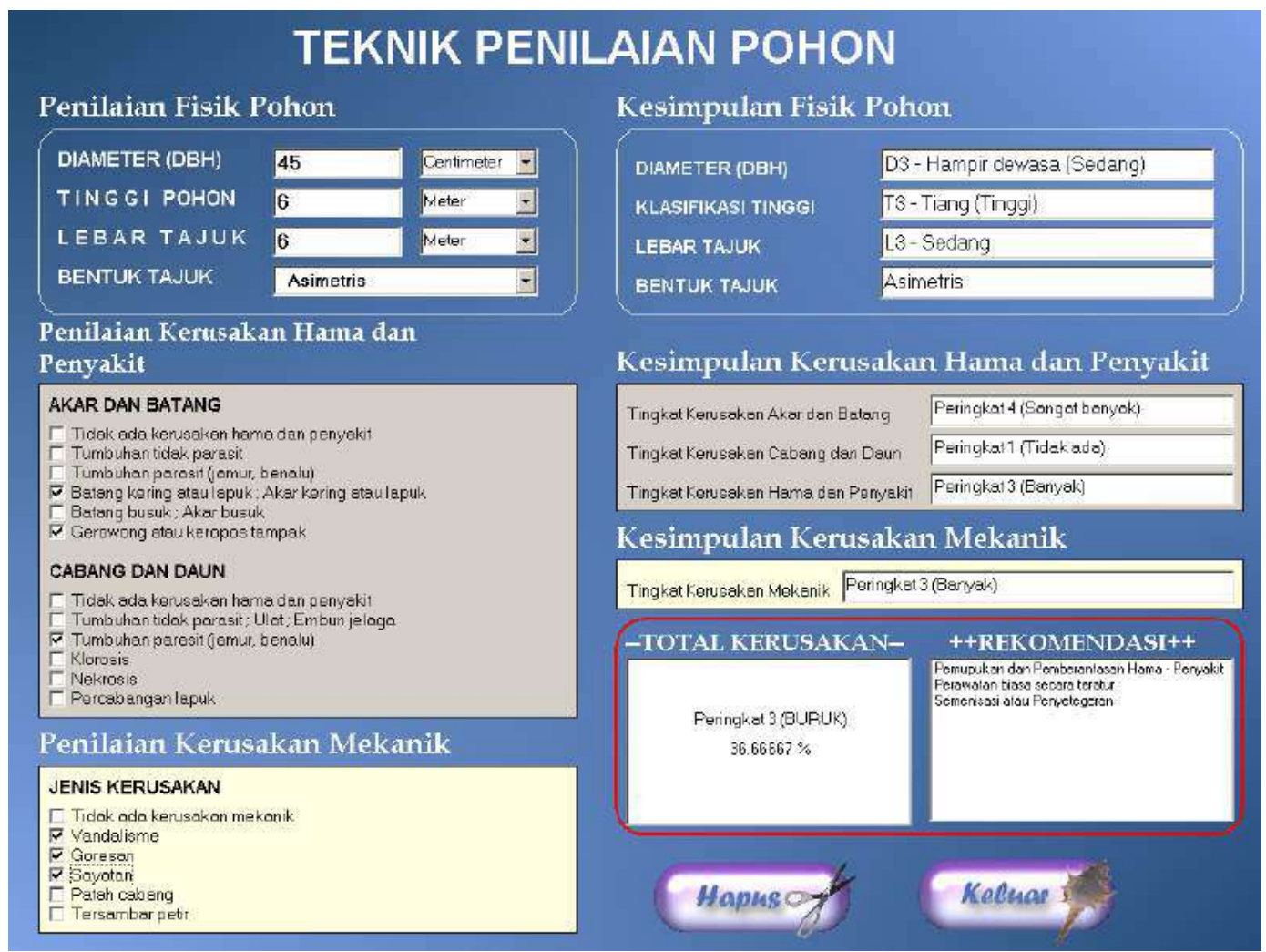


Wilayah KotamadyaJakarta Timur

\subsection{POTENSI PENGEMBANGAN PENGELOLAAN RUANG TERBUKA HI- JAU (RTH)}

Sasaran pengelolaan penghijauan yang akan dilaksanakan ke depan adalah mengacu kepada penyediaan luasan Ruang Terbuka Hijau sesuai RTRW 2010, disamping ruang-ruang kota lain yang memungkinkan dapat dijadikan media penanaman pohon/tanaman. Untuk itu potensi-potensi yang masih dapat dikembangkan adalah:

Pengembangan Ruang Terbuka Hijau yang meliputi:

- Ruang Terbuka Hijau Fasilitas sosial atau fasilitas umum antara lain: Taman Kota, Taman Hutan/Hutan Kota, Taman Rekreasi.

- Ruang Terbuka Hijau Pemakaman.

- Ruang Terbuka Hijau pengaman antara lain: jalur hijau tegangan tinggi, jalur hijau jalan, jalur hijau sungai atau tepian air.

Disamping itu juga pemanfaatan ruang-ruang kota lain seperti:

- Kawasan pemukiman atau perkantoran.

- Kawasan perkantoran.

- Kawasan industri.

Untuk merealisasikan hal yang disebutkan diatas pihak dinas pertamanan mengadakan program sasaran penghijauan di DKI Jakarta dengan langkahlangkah sebagai berikut:

- Membuka lahan hijau baru dengan pembebasan tanah khususnya pada daerah-daerah padat penduduk sebagai wadah masyarakat berinteraksi atau berekreasi (perluasan lahan hijau).

- Melaksanakan penanaman pohon secara massal pada lokasi-lokasi RTH dan atau ruang-ruang kota lain yang memungkinkan.

- Melakukan reboisasi pada kawasan hijau lindung atau alami dan rehabilitasi penghijauan dengan tanaman-tanaman berkualitas, baik tanaman estetis maupun produksi.

- Serta upaya lain untuk meningkatkan kawasan hijau (lahan maupun ruang) baik dilakukan oleh PEMDA dan atau melalui peran serta masyarakat. 


\section{BAB 5 \\ PEN U T U P}

Pembangunan Sistem Informasi Manajemen RTH Taman dan Jalur Hijau Wilayah Kotamadya Jakarta Timur adalah suatu langkah penting dalam pengembangan dan pengelolaan Ruang Terbuka Hijau (RTH) di Jakarta Timur. Pengelolaan Ruang Terbuka Hijau (RTH) yang baik akan menunjang keindahan dan kenyamanan kota. Dalam studi ini, telah disusun data yang cukup lengkap dan memadai mengenai tanaman penyusun lanskap (pohon), sebagai salah satu elemen utama Ruang Terbuka Hijau (RTH) di Wilayah Kotamadya Jakarta Timur.

Ruang Terbuka Hijau Pertamanan dan Jalur Hijau yang disurvey terdiri atas 5 jalur hijau utama, yaitu: (1) Jalur Hijau Jalan Raya Bogor; (2) Jalur Hijau Jalan Mayjen Sutoyo; (3) Jalur Hijau Jalan Jenderal Ahmad Yani; (4) Jalur Hijau Jalan Kalimalang; dan (5) Jalur Hljau Jalan Kayu Putih Raya. Sedangkan Ruang Terbuka (RTH) taman yang disurvey terdiri atas: (1) Taman Hutan Kota Kompleks Perumahan karyawan Pemda DKI Pondok Kelapa, Duren Sawit, dan; (2) Taman Dermaga, Duren Sawit.

Data inventarisasi yang disusun yaitu terdiri atas pemetaan letak titik pohon dan penilaian kondisi fisiknya yang bermanfaat sebagai data dasar (basic data) bagi penyusunan kegiatan pengelolaan Ruang Terbuka Hijau (RTH) di wilayah Kotamadya Jakarta Timur.

Selain laporan utama, disusun pula buku manual (manual book) sebagai panduan pengoperasian sistem informasi pengelolaan RTH Taman dan Jalur Hijau untuk memudahkan dalam pengaplikasian teknis di lapang.

Data yang disurvey merupakan kondisi aktual pada saat studi ini dilakukan, sehingga apabila di masa akan datang dilakukan peninjauan kembali, maka diperlukan updating data untuk menjamin validitas data itu sendiri. 


\section{DAFTAR PUSTAKA}

Alam, MAJ. 2005. Mengolah Database dengan SQL dan Microsoft Query dalam Microsoft Excel. Elex Media Komputindo Gramedia. Jakarta.

Anderson, D. dan M.W. Leiserson. 1980. Rural Non-Farm Employment in Developing Countries. Economic Development and Cultural Change, 28(2), Jan.

Arnold, H. F. 1980. Tree In Urban Design. Vand Nostrand Reinhold Co. Inc. New York. 168hal.

Arifin, H.S.A dan Nurhayati. 2000. Pemeliharaan Taman. Penebar Swadaya. Jakarta. 123hal.

Aronoff, S., 1989. GIS: A Management Perspective. WDL Publications, Ottawa, Canada.

Barus, B. dan U.S. Wiradisastra, 2000. Sistem Informasi Geografi (Sarana Manajemen Sumber Daya). Laboratorium Penginderaan Jauh dan Kartografi Jurusan Tanah, FAPERTA, IPB, Bogor.

Booth, N.K. 1983. Basic Elements of Landscape Architectural Design. Waveland Press, Inc. Illinois. 315p.

Carpenter, P.L., T.D. Walker dan F.O. Lanphear. 1975. Plants in the Landscape. W.H. Freeman and Co. San Fransisco. 481p.

Dahlan, E. N. 1992. Hutan Kota: Untuk Pengelolaan dan Peningkatan Kualitas Lingkungan Hidup. Asosiasi Pengusaha Hutan Indonesia. Jakarta. 92hal.

Dasmann, R.F., 1972. Environment Conservation. Third Edition. John Wiley and Sons, Inc. New York.

Davis, G., 1995. Kerangka Dasar Sistem Informasi Manajemen. PT. Pustaka Binama Pressindo. Jakarta. 68hal.

Depdagri. 1988. Instruksi Mendagri No.14. Jakarta. 20hal.

Dinas Pertamanan DKI Jakarta, 1993. Gerakan Sejuta Pohon Menuju Jakarta Berwawasan Lingkungan. Yayasan Pendidikan Kelestarian Alam dan Majalah ASRI. Jakarta.

Dinas Pertamanan dan Keindahan Kota DKI Jakarta. 2001. Daftar Istilah. Jakarta. Tidak Dipublikasikan. 1hal.

Direktorat Jenderal Bina Marga. 1996. Tata Cara Perencanaan Teknik Lanskap Jalan. Direktorat Jenderal Bina Marga. Departemen Pekerjaan Umum. Jakarta. 52hal. 
Wilayah KotamadyaJakarta Timur

Grey, G.W. dan F.I. Deneke. 1986. Urban Forestry. John Wiley and Sons, Inc. New York.

Hernowo, T.B., dan L.B. Prasetyo. 1989. Konsepsi Ruang Terbuka Hijau di Kota Sebagai Pendukung Pelestarian Burung. Media Konservasi. 2(4): hal 6171.

International Society of Arboriculture (ISA). 2005. Forest and Shade Tree Pathology: Hazard Trees. International Society of Arboriculture. http://www.forestpathology.org/hazard.html.

Jumarni, N. 2004. Penilaian Kondisi Fisik Pohon Tepi Jalan di Lingkar Kebun Raya Bogor, Jawa Barat (Studi Kasus di JI IR H Juanda, JI Salak Harupat, JI Raya Pajajaran dan JI Otto Iskandar Dinata). Jurusan Budidaya Pertanian, Fakultas Pertanian, Institut Pertanian Bogor. Tidak Dipublikasikan.

Kementerian Lingkungan Hidup. 2004. Pedoman Umum Penanaman Jalur Hijau Jalan. Jakarta. 28hal.

Kunto, H. 1986. Semerbak Bunga di Bandung Raya. P.T. Granesia. Bandung.

Miller, R. W. 1988. Urban Forestry : Planning and Managing Urban Greenspace. Prentice Hall, Inc. New Jersey. 404hal.

Moekijat. 1991. Pengantar Sistem Informasi Manajemen. PT. Remaja Rosdakarya. Bandung. 97hal.

Noor, M.Z. 1990. Aspek Pendidikan Arsitektur Lansekap dalam Menunjang Pembinaan Ruang Terbuka Hijau Kota. Makalah pada Seminar Ruang Terbuka Hijau. Jakarta. 13hal.

Nurfaida. 1997. Studi Perencanaan Lanskap Di Taman Wisata Alam Bantimurung Kabupaten Maros Sulawesi Selatan. Jurusan Budidaya Pertanian, Fakultas Pertanian, Institut Pertanian Bogor. Tidak Dipublikasikan.

Nurisyah, S. 1991. Tanaman Untuk Taman dan Lansekap Kota. Kerjasama Lembaga Pengabdian pada Masyarakat IPB dengan Fakultas Pertanian IPB. Bogor. 17hal.

Pamungkas. 2005. Trik Pemrograman Microsoft Excel. Elex Media Komputindo Gramedia. Jakarta.

Pirone, P. P. 1972. Tree Maintenance. Oxford University Press. New York. 574hal.

Prahasta, E. 2002. Konsep-konsep Dasar Sistem Informasi Geografi. Penerbit Informatika. Bandung.

Purnamasari, E. 2003. Studi Keberadaan dan Kondisi Fisik Pohon Kenari (Canarium communae L.) Sebagai Pohon Tepi Jalan di Jalan Pemuda dan Jalan Ahmad Yani, Kota Bogor. Jurusan Budi Daya Pertanian. 
Wilayah KotamadyaJakarta Timur

Fakultas Pertanian. Institut Pertanian Bogor. Bogor. Tidak Dipublikasikan. 54hal.

Rahayu, S. 1999. Penyakit Tanaman Hutan di Indonesia: Gejala, Penyebab, dan Teknik Pengendaliannya. Penerbit Kanisius. Yogyakarta. 112hal.

Simonds, J.L. 1983. Landscape Architecture. Mc. GrawHill Co. New York. 331p.

Society of American Foresters. 1944. Forest Terminology. Society of American Foresters. America. 210p.

Soemarwoto, O. 1994. Ekologi, Lingkungan Hidup dan Pembangunan. Djambatan. Jakarta. 365hal.

Sternloff, R.E dan R. Warren. 1984. Park and Recreation Maintenance Management. John Wiley and Sons. 327p. 
Wilayah KotamadyaJakarta Timur

\section{A M P I R A N}

